\title{
ASPECTOS EPIDEMIOLÓGICOS DA MALÁRIA HUMANA E SIMIANA EM ÁREA DE INFLUÊNCIA DO RESERVATÓRIO DA USINA HIDRELÉTRICA DE PORTO PRIMAVERA, MUNICÍPIO DE PRESIDENTE EPITÁCIO, SÃO PAULO, BRASIL.
}

\author{
ANA MARIA RIBEIRO DE CASTRO DUARTE
}

Tese de Doutorado apresentada ao Departamento de Epidemiologia da Faculdade de Saúde Pública da Universidade de São Paulo, para obtenção do Grau de Doutor.

Área de Concentração: Epidemiologia

Orientador: Prof. Dr. Almério de Castro Gomes

São Paulo

2003 
Esta tese foi realizada com o apoio financeiro da Fundação de Amparo à Pesquisa do Estado de São Paulo (FAPESP) - Bolsa de Doutorado no 99/02792-2 e Auxílio à Pesquisa nº 99/02570-0. 
Ao

meu pai Francisco (in memoriam),

sempre presente em meus pensamentos, atitudes e sentimentos.

Ao

meu filho Adriano,

com quem tenho aprendido o verdadeiro

significado do amor e da responsabilidade. 
Ao

meu esposo Ricardo,

pelo amor e companheirismo dedicados

a mim e ao Adriano.

$\grave{A}$

minha mãe Vicentina,

Pela dedicação e carinho à minha família.

Ao

Prof. Dr. Almério de Castro Gomes,

pela preciosa amizade e confiança depositada no meu trabalho. 
"Aquele que procura instruir-se deve em primeiro lugar saber duvidar, pois a dúvida do espírito conduz a descobrir a verdade”.

(Aristóteles)

“Para enxergar claro, basta mudar a direção do olhar”. (Antoine Saint-Exupéry) 


\section{AGRADECIMENTOS}

Às minhas "amigas-irmãs" de hoje e sempre Izilda Curado e Maura Antonia Lima Porto, por tudo que vivemos até este momento.

Em especial à Rosely dos Santos Malafronte, por sua sincera amizade e seus preciosos ensinamentos, por suas posturas éticas e transparentes, baseadas nos ensinamentos aprendidos com a nossa "eterna" orientadora Prof ${ }^{\mathrm{a}}$. Dr ${ }^{\mathrm{a}}$ Judith Kardos Kloetzel.

À Maria Dulce Bianchi Rosa, do laboratório de Doenças Tropicais do Departamento de Epidemiologia, pela sincera amizade e apoio incondicional.

À Byanca Regina Paiva e Adriana Yurika Maeda pela amizade e auxílio fundamental nas atividades laboratoriais.

À Maria Stela Branquinho, pelo companheirismo e incentivo no início de minha carreira.

Ao Dr. Heitor Franco de Andrade Jr., pela infra-estrutura do Laboratório de Protozoologia do Instituto de Medicina Tropical de São Paulo USP, e por todo apoio e colaboração que me ofereceu no período que lá permaneci.

Aos professores Délsio Natal, Eunice Bianchi Gallati e José Maria Soares Barata, pelo apoio e confiança dedicados durante o desenvolvimento deste trabalho no Departamento de Epidemiologia.

À Dra. Mércia E. de Arruda, do Centro de Pesquisas Aggeo Magalhães-FNS, pela amizade com nosso grupo de pesquisa e pela preciosas críticas, sugestões e contribuições feitas ao Projeto.

Ao pessoal da Secretaria do Departamento de Epidemiologia, Valdeci, Rosana, Leni, Malu e Agnaldo, pelo apoio imprescindível.

Ao pessoal do Laboratório de Entomologia do Departamento de Epidemiologia, "Waltinho" e Paulo, e em especial Márcia Bicudo e Márcia Gutierrez, pela sincera amizade e assessoria no desenvolvimento dos projetos.

Ao colega Luis Filipe, pela amizade e auxilio nos relatórios.

Ao Rodrigo pela ajuda e "paciência" nos trabalhos de computação. 
Ao pessoal do Laboratório de Protozoologia, do Inst. de Medicina Tropical de São Paulo, pela amizade e apoio que sempre me proporcionaram.

Ao pessoal da Biblioteca do Instituto de Medicina Tropical de São Paulo, em especial Sônia Pedrozo Gomes e Adenilson Leite Ribeiro.

Aos funcionários da CESP (Companhia Energética de São Paulo) das unidades de Porto Primavera e Presidente Epitácio, em especial, ao Dr. Lúcio de Oliveira e Souza, chefe da divisão veterinária.

Ao Fundo de Amparo à Pesquisa do Estado de São Paulo (FAPESP), ao Departamento de Epidemiologia da FSP, ao Instituto de Medicina Tropical de São Paulo-FMUSP e ao Laboratório de Investigação Médica (LIM-49)-FMUSP, pelo apoio financeiro na realização deste trabalho.

Aos meus inúmeros parentes, amigos e colegas, que não foram citados aqui, saibam que estão todos devidamente "listados" em meu coração. 


\section{RESUMO}

Duarte AMRC. Aspectos Epidemiológicos da Malária Humana e Simiana em Área de Influência do Reservatório da Usina Hidrelétrica de Porto Primavera, Município de Presidente Epitácio, São Paulo, Brasil. São Paulo; 2003 [Dissertação de Doutorado - Faculdade de Saúde Pública da USP].

Objetivo: Verificar a prevalência de infecções maláricas, anticorpos contra formas infectantes (esporozoítos) e anticorpos contra formas sangüíneas (assexuadas) de plasmódios, nas populações humanas e de bugios (Alouatta caraya), que habitam a região do reservatório da UHE de Porto Primavera, no Município de Presidente Epitácio, no Estado de São Paulo; área com história de malária autóctone. Comparar os resultados encontrados em ambas populações e realizar análise epidemiológica sobre o risco da re-introdução da malária na região e a possibilidade do envolvimento de bugios no ciclo de transmissão.

Métodos: Amostras de sangue de 216 moradores de duas áreas que se situam às margens do reservatório, Campinal (área nativa) e Reassentamento Lagoa São Paulo (RLSP); e amostras de sangue de 239 bugios capturados nas matas ciliares das margens correspondentes aos lados do de São Paulo e Mato Grosso do Sul, por ocasião das inundações do lago artificial. Foram realizados exame parasitológico de gota espessa e esfregaço sangüíneo e reação de polimerização em cadeia (PCR), com "primers" correspondentes a região $18 \mathrm{~S}$ rRNA gênero específica de plasmódio e, "primers" correspondentes ao gene da proteína circumsporozoíta (CS) de Plasmodium vivax, P. falciparum e $P$. malariae, para identificação de infecções maláricas. Foram realizados os seguintes testes sorológicos para detecção de anticorpos da classe IgG: ELISA com peptídeos sintéticos correspondentes à região repetitiva da proteína CS de $P$. vivax "clássico (VK210) (Pvc), P. vivax "variante" (VK247) (Pvk), P. vivax-like humano (Pvl), P. malariae/P.brasilianum $(\mathrm{Pm} / \mathrm{Pb})$ e $P$. 
falciparum (Pf), e Imunofluorescência Indireta (IFI) com antígenos de formas sangüíneas de $P$. vivax, $P$. falciparum e $P$. malariae.

Resultados: No exame parasitológico, foram encontradas formas semelhantes ao $P$. vivax em 7 lâminas de gota espessa (2,9\%) de bugios, sendo 2 espécimes de São Paulo (SP) e 5 do Mato Grosso do Sul (MS). Na técnica de PCR, foram observadas amplificações em 7 amostras de DNA de bugios (4 de SP e 3 do MS) com os "primers" $18 \mathrm{~S}$ rRNA gênero específico (2,9\%), sendo que destas, 4 amplificaram também com os "primers" correspondentes ao gene CS de $P$. vivax, e 2 com "primers" espécie especificos de $P$. falciparum (18S rRNA) . Não foram observadas amplificações nas 7 amostras positivas testadas com os "primers" CS de $P$. falciparum e $P$. malariae. Não foram identificadas infecções maláricas na população humana amostrada, por meio dos métodos utilizados. Na reação de ELISA verificamos alta prevalência de anticorpos contra a proteína CS com os peptídeos do "Complexo vivax" na população humana (17,6\%). No Campinal a positividade foi de $22,3 \%$, sendo a maioria dos soros positivos com o peptídeo Pvc (11,5\%), no RLSP a positividade foi de 10,5\%, sendo a prevalência maior para o peptídeo Pvl (7,0\%). A prevalência com os peptídeos $\mathrm{Pm} / \mathrm{Pb}$ e Pf foi de 3,8\% para ambos no Campinal, e de $2,3 \%$ e $7,0 \%$ no RLSP, respectivamente. Na reação de IFI com antígeno de P.vivax, a positividade total foi de $20,8 \%$, sendo $21,5 \%$ no Campinal e $19,8 \%$ no RLSP. Os soros humanos foram negativos com os antígenos de P. falciparum e P.malariae. Na população de bugios foi verificada também alta prevalência de anticorpos com os peptídeos do "Complexo vivax", sendo $19,6 \%$ e $8,8 \%$ nos bugios de SP e MS, respectivamente. Houve maior predominância de soros positivos com peptídeo Pvk em ambas localidades. A positividade com os peptídeos $\mathrm{Pm} / \mathrm{Pb}$ e $\mathrm{Pf}$ foi de $12,7 \%$ e $10,8 \%$ nos macacos de SP, respectivamente; e 7,3\% nos macacos de MS, para ambos os peptídeos. Na reação de IFI, foi observada alta prevalência de anticorpos contra formas sangüineas de $P$. vivax nos bugios (17,6\%), sendo $15,7 \%$ e $19,0 \%$ nos bugios de SP e MS, respectivamente. Com o antígeno de $P$. falciparum a prevalência na totalidade da amostra foi de 5,0\%, sendo $5,9 \%$ e $4,4 \%$ nos bugios de SP e MS, respectivamente. Com o antígeno de $P$. malariae a positividade foi de $13.4 \%$, sendo $9.8 \%$ e $16.1 \%$ nos bugios de SP e MS, respectivamente. 
Conclusões: Não foi observada a circulação de plasmódios na população humana, entretanto foi verificada a presença de $P$. vivax $e$ P. falciparum nos bugios. A prevalência de anticorpos contra esporozoítos (proteína $\mathrm{CS}$ ) de plasmódios ( $P$. vivax, P. falciparum e P.malariae), indicou que ambas populações, humanas e de bugios da área de estudo, entram em contatos com estes parasitos. A prevalência de anticorpos contra formas sangüíneas indicou o desenvolvimento de infecções maláricas em ambas populações, humanas e de bugios, sugerindo a ocorrência de quadro assintomático entre humanos e confirmando a ocorrência de infecção entre os macacos. A comparação dos resultados sugere a ocorrência de um quadro de transmissão na população de bugios, que possivelmente envolve a população humana na situação epidemiológica atual. Em função dos resultados das pesquisas entomológicas conduzidas paralelamente na mesma área de estudo, indicarem o aumento da densidade de espécies vetoras, este quadro pode mudar, e com isso prevemos o aumento do risco da re-introdução da malária na população humana.

Descritores: Malária. Plasmodium.Epidemiologia. Macacos. 


\section{SUMMARY}

\section{Duarte AMRC. Epidemiological Aspects of Human and Simian Malaria in the}

Influence Area of the Reservoir of the Hydroeletric Plant at Porto Primavera, Municipality of Presidente Epitácio, State of São Paulo, Brazil. São Paulo, 2003. [Ph. H.D. Dissertation- Faculdade de Saúde Pública - Universidade de SãoPaulo].

Objective: Verify the prevalence of malaria infections, anti-plasmodia infective forms (sporozoite) antibodies and anti-blood forms (asexual) antibodies in human and howler monkey (Alouatta caraya) populations living in the region of the HP reservoir at Porto Primavera, Municipality of Presidente Epitácio, State of São Paulo, an area known for autochtonous malaria in the past. Compare results obtained for both populations and make and epidemiological analysis of the risk of re-introducing malaria in the region and the possibility of involving howler monkeys in the transmission cycle.

Methods: Blood samples from 216 people living in the two areas at the margins of the reservoir, Campinal (native area) and Reassentamento Lagoa São Paulo (RLSP) as well as blood samples from 239 howler monkeys captured at the time of forest flooding for the artificial lake, corresponding to both the margins at the São Paulo and Mato Grosso do Sul sides. To identify malaria infection, thick and thin blood smears were subjected to parasitological microscopic observations as well as polymerized chain reactions (PCR) with the $18 \mathrm{~S}$ rRNA Plasmodium genus specific primer and primers for the circumsporozoite protein (CS) of Plasmodium vivax, P. falciparum and $P$. malariae. To detect IgG antibodies the following serological tests were made: ELISA with synthetic peptides corresponding to the repetitive region of the CS of $P$. vivax "classic" (VK210) (Pvc), P. vivax "variant" (VK247) (Pvk), human P.vivax-like $(\mathrm{Pvl})$, P.malariae/P.brasilianum $(\mathrm{Pm} / \mathrm{Pb})$ and $P$. falciparum $(\mathrm{Pf})$ as well as Indirect 
Immunofluorescence Assay (IFA) with blood form of $P$. vivax, $P$. falciparum and $P$. malariae as antigens.

Results: On microscopic observation of the howler monkeys thick blood preparations $7(2.9 \%)$ were found to have forms similar to $P$. vivax. Two of these were from São Paulo (SP) and 5 from Mato Grosso do Sul (MS). PCR with the 18S rRNA genus specific primer amplified the DNA of 7 howler monkeys samples (4 from SP and 3 from MS); four of these were also amplified by primers corresponding to the CS gene of $P$. vivax, and 2 by the $P$. falciparum specific primers (18S rRNA), none of the 7 positive samples were amplified by the CS $P$. falciparum and $P$. malariae specific primers. No malaria infections were identified in the human population samples by the above methods. A high prevalence of the anti-CS antibodies was found in ELISA with the "Vivax Complex" peptides in the human population (17.6\%). At Campinal positivity was $22.3 \%$, most of the sera testing positive with the Pvc peptide (11.5\%). At RLSP overall positivity was $10.5 \%$, prevalence being higher for the Pvl peptide (7.0\%). With both the $\mathrm{Pm} / \mathrm{Pb}$ and $\mathrm{Pf}$ peptides prevalence was 3.8\% in Campinal, $2.2 \%$ and $7.0 \%$ respectively in RLSP. In IFA reaction total positivity was $20.8 \%, 21.5 \%$ in Campinal sera and $19.8 \%$ in those of RLSP. All human sera tested negative with the $P$. falciparum and $P$. malariae antigens. High prevalence of antibodies against peptides of the "Vivax complex" was also found in the howler monkey population, $19.6 \%$ and $8.8 \%$ in those of SP and MS respectively. Pvk peptide positive sera predominated in both localities. Positivity with $\mathrm{Pm} / \mathrm{Pb}$ and $\mathrm{Pf}$ peptides was $12.7 \%$ and $10.8 \%$ respectively in monkeys from SP and $7.3 \%$ for both peptides in MS monkeys. High prevalence of IFA with anti blood forms antigen of $P$. vivax was found in howler monkeys (17.6\%), $15.7 \%$ and $19.0 \%$ in SP and MS monkeys respectively. With the $P$. falciparum antigen total prevalence of the sample was $5.0 \%, 5.9 \%$ and $4.4 \%$ respectively with SP and MS monkey sera. With the $P$. malariae antigen total prevalence of the samples was $13.4 \%, 9.8 \%$ and $16.1 \%$ respectively with SP and MS monkey sera.

Conclusions: No plasmodia were detected in the blood circulation of the human population, however $P$. vivax and $P$. falciparum was detected in howler monkeys. 
The prevalence of plasmodia anti-sporozoite protein antibodies (CS) (P. vivax, $P$. falciparum and $P$. malariae) indicates that both the human and howler monkey population in the area have contact with these parasites. The prevalence of anti parasite blood form antibodies indicated the development of malaria infections in both the human and howler monkey population, suggesting asymptomatic infections in human beings and confirming infections in monkeys. Comparing results of tests suggests the transmission of malaria infection in the monkey population which does probably involve humans at the present epidemiological situation. Parallel entomological research carried out in the same area indicates an increase in density of vector species with possible changes the situation and we thus foresee an increased risk of re-introducing malaria in the human population.

Descriptors: Malaria. Plasmodium. Epidemiology. Monkeys. 


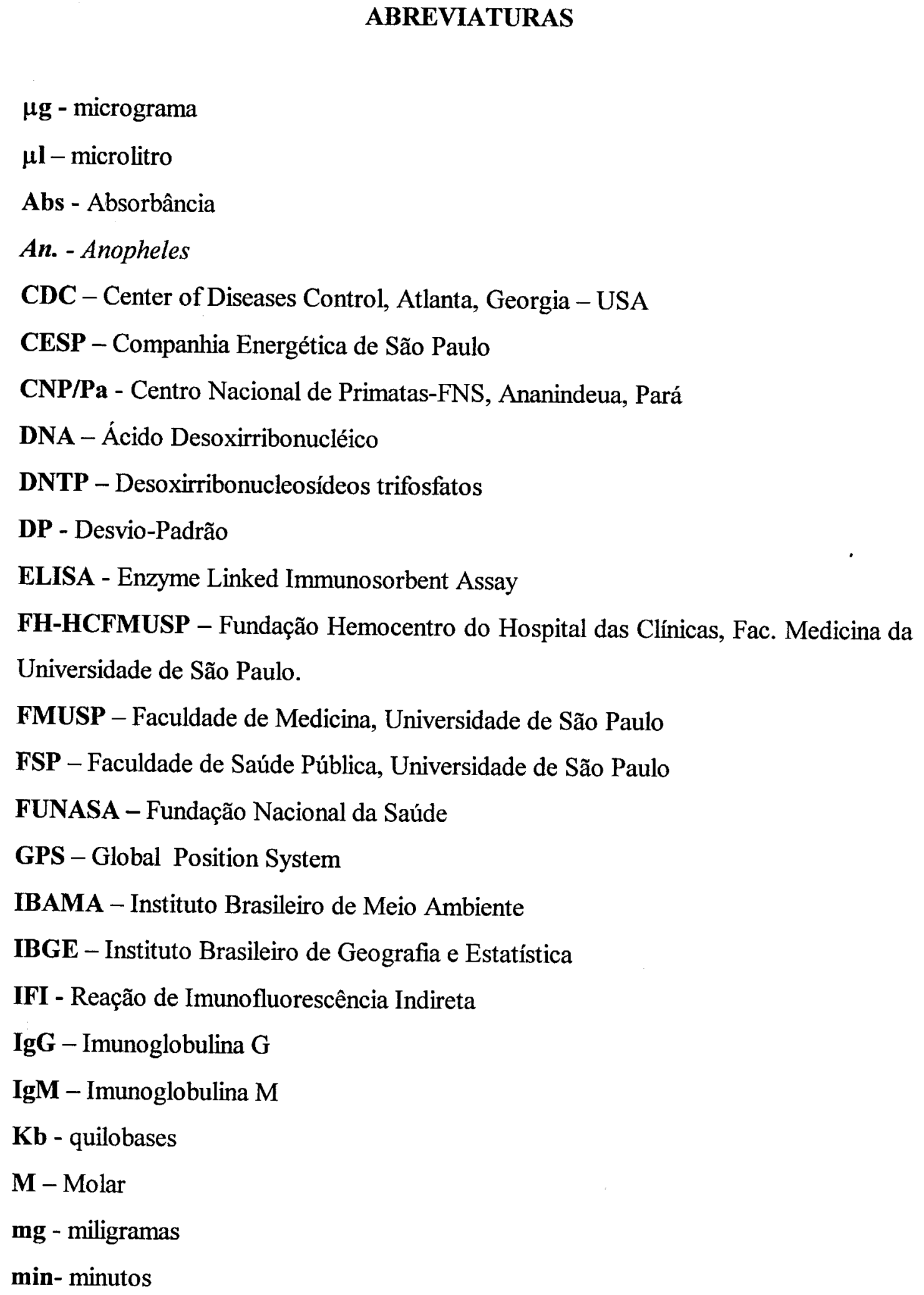


ml-mililitros

mM - milimolar

MS - Mato Grosso do Sul

ng - nanograma

${ }^{\circ} \mathbf{C}$ - Grau Celsius

OMS - Organização Mundial de Saúde

pb - pares de bases

PCR - Reação de Polimerização em Cadeia

pH - Potencial Hidrogeniônico

Proteína CS - Proteína Circumsporozoíta

Pf - Plasmodium falciparum

$\mathbf{P m} / \mathbf{P b}$ - Plasmodium malariae/Plasmodium brasilianum

Pvc - Plasmodium vivax Tipo I (clássico)

Pvk - Plasmodium vivax Tipo II - variante VK247

Pvl - Plasmodium vivax-like humano

RLSP - Reassentamento Lagoa São Paulo

rRNA - ácido ribonucléico ribossômico

seg - segundos

SP - São Paulo

SUCEN - Superintendência de Controle de Endemias

TA - Temperatura Ambiente

Taq - enzima isolada de Thermus aquaticus

$\mathrm{U}$ - unidade de enzima

UV - Ultra-Violeta

UHE - Usina Hidrelétrica

WHO - World Health Organization 


\section{ÍNDICE}

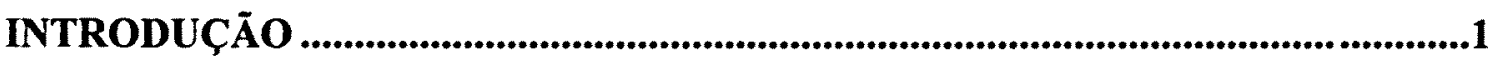

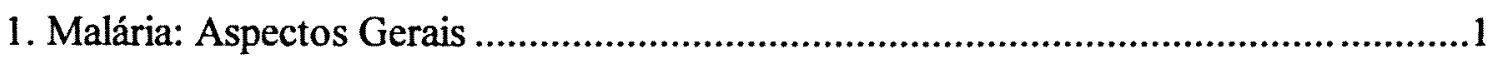

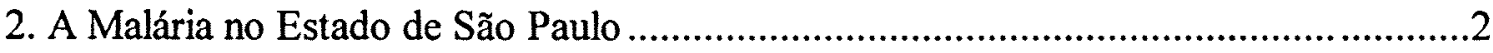

3. Malária Humana e Simiana: Similaridade e Aspectos Epidemiológicos. .........................3

3.1. Plasmódios Simianos e Seus Hospedeiros Naturais .................................................

3.2. Plasmódios Simianos e Macacos do Novo Mundo.................................................10

3.2.1. Plasmodium brasilianum .................................................................................. 10

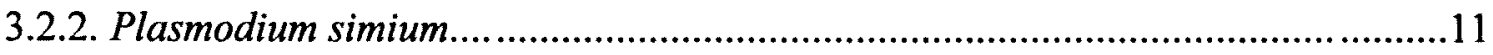

3.3. Dados Epidemiológicos da Malária Simiana no Brasil............................................12

3.4. Similaridades e Homologias Parasitológicas e Imunológicas...................................15

3.5. Proteína Circumsporozoíta (CS) e as Relações entre os Plasmódios Simianos e

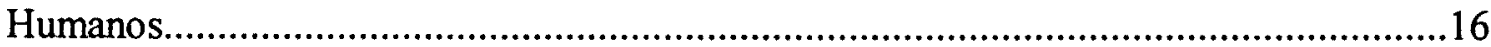

3.6. Malária, Usinas Hidrelétricas e Impacto Ambiental.................................................23

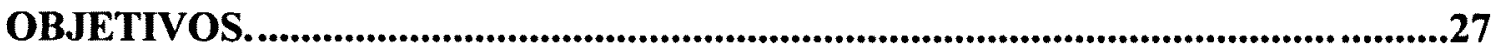

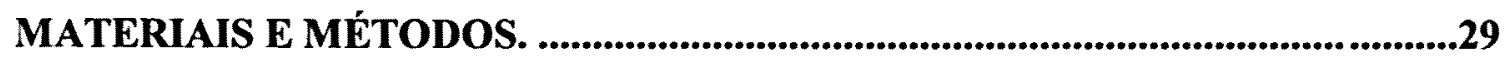

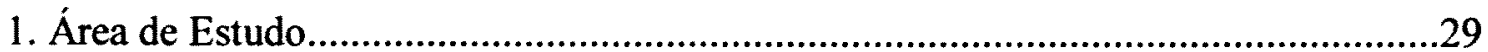

2. Inquérito Epidemiológico, Definição da Amostra e Coleta de Sangue da População

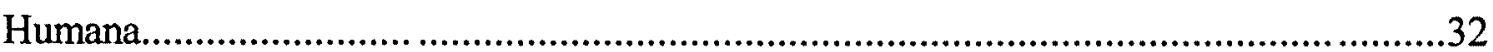

3. Coleta de Sangue de Macacos Capturados nas Áreas de Inundação da UHE de Porto

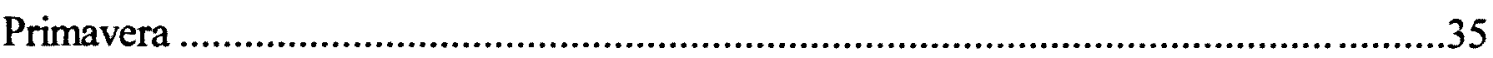

4. Exame Parasitológico Direto - Teste de Gota Espessa e Esfregaço Sangüíneo...........36

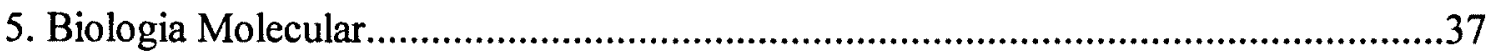

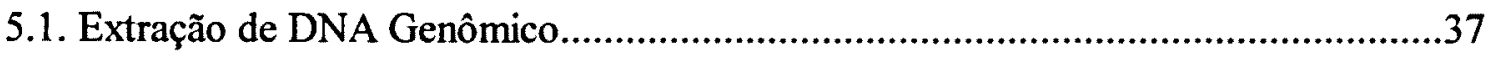

5.2. Reação de Polimerização em Cadeia - "PCR".........................................................37

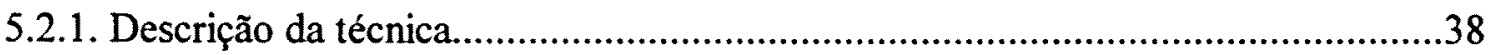

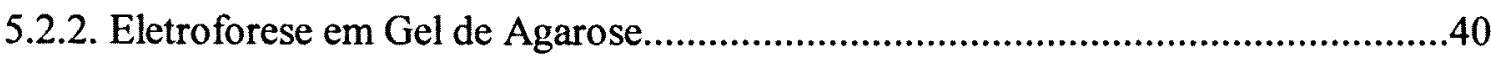




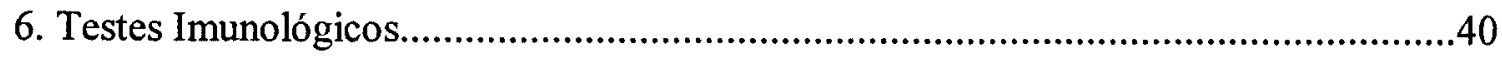

6.1. Reação de ELISA (Enzyme Linked-Immunosorbent Assay)...................................40

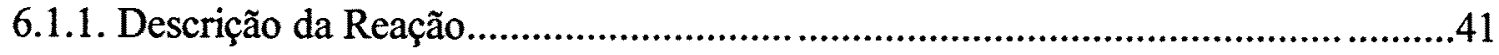

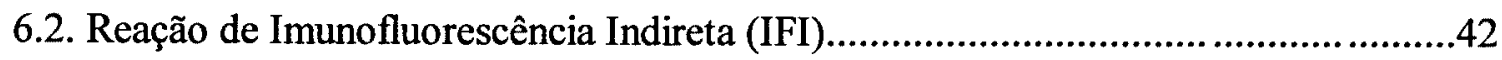

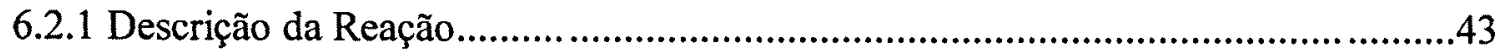

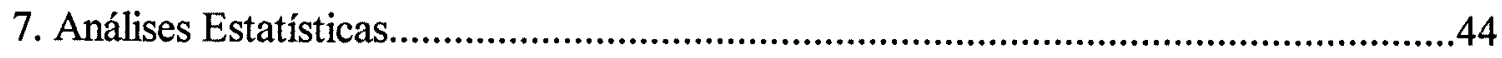

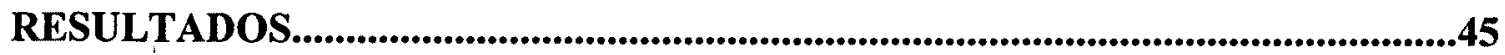

1. Características Demográficas e Ocupacionais da Amostra Humana...........................45

1.2. Resultado do Exame Parasitológico de Gota Espessa e Esfregaço da Amostra

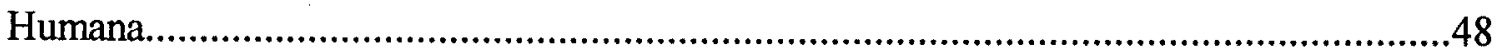

1.3. Resultados da Reação de Polimerização em Cadeia (PCR) com Amostras de DNA

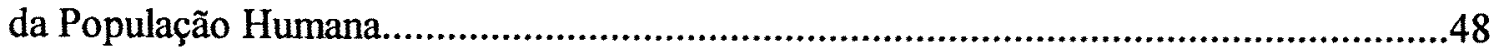

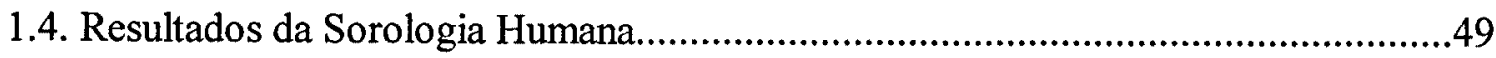

1.4.1. Determinação dos Limiares de Reatividade (“cut-off') na Reação de ELISA para

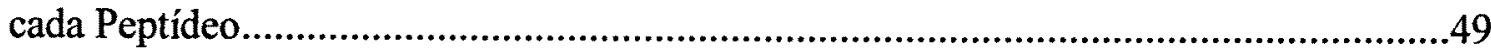

1.4.2. Resultados das Reações de ELISA na Amostra Humana......................................50

1.4.3. Determinação do Limiares de Reatividade ("cut-off") na Reação de Imunofluorescência Indireta (IFI) para cada Antígeno..................................................55

1.4.4. Resultados das Reações de Imunofluorescência Indireta (IFI) na Amostra Humana.

1.4.5. Resultados das Reações de ELISA e IFI na Amostra Humana de Acordo com o Sexo

1.4.6. Resultados das Reaç̃es de ELISA e IFI na Amostra Humana de Acordo com a Faixa Etária

1.4.7. Resultados das Reações de ELISA e IFI na Amostra Humana de Acordo com a Ocupação.

1.4.8. Resultados das Reações de ELISA e IFI na Amostra Humana de Acordo com o Tempo de Residência na Área.

1.4.9. Comparação entre os Resultados Positivos para Anticorpos Contra Proteína CS (ELISA) e Contra Formas Assexuadas (IFI) de P. vivax 
2. Perfil Populacional da Amostra de Bugios.

2.1. Resultado do Exame Parasitológico de Gota Espessa e Esfregaço da Amostra de Bugios (Alouatta Caraya)

2.2. Resultados da Reação de Polimerização em Cadeia (PCR) com Amostras de DNA de Bugios (Alouatta caraya) .72

2.3. Resultados da Sorologia da Amostra de Bugios (Alouatta caraya). .80

2.3.1. Determinação dos Limiares de Reatividade ("cut-off") na Reação de ELISA para cada Peptídeo. .80

2.3.2. Resultados das Reações de ELISA na Amostra de Bugios. . .81

2.3.3. Determinação do Limiares de Reatividade ("cut-off") na Reação de

Imunofluorescência Indireta (IFI) para cada Antígeno. . .85

2.3.4. Resultados das Reações de Imunofluorescência Indireta (IFI) na Amostra de Bugios

2.3.5. Resultados das Reações de ELISA e IFI na Amostra de Bugios de Acordo com o Sexo.

2.3.6. Resultados das Reações de ELISA e IFI na Amostra de Bugios de Acordo com a Faixa Etária

2.3.7. Comparação entre os Resultados Positivos para Anticorpos Contra Proteína CS (ELISA) e Contra Formas Assexuadas (IFI) de $P$. vivax, $P$. malariae e P. falciparum na Amostra de Bugios.

2.3.8. Comparação entre os Resultados Positivos para Anticorpos Contra Proteína CS (ELISA) e Contra Formas Assexuadas (IFI) de $P$. vivax, $P$. malariae e $P$. falciparum na Amostra Humana e de Bugios Capturados no Lado de São Paulo.................................93

DISCUSSÃ

CONCLUSÕES...........................................................................................118

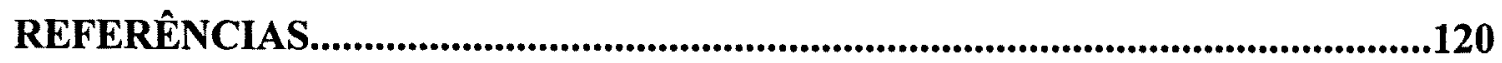
ANEXOS 


\section{INTRODUÇÃO}

\section{Malária: Aspectos Gerais}

A malária é uma doença parasitária causada por protozoários do Filo Apicomplexa do gênero Plasmodium, transmitida por mosquitos anofelinos (Dípteros da família Culicidae, gênero Anopheles). Seus principais sintomas são febre intermitente, cefaléia, anemia e esplenomegalia.

Foram descritas aproximadamente 100 espécies de plasmódios, sendo que a maioria infecta macacos, aves, répteis, aves e mamíferos; quatro são infectantes para o homem: Plasmodium falciparum, P. vivax, $P$. malariae e $P$. ovale (REY, 1991).

Esta moléstia representa um dos mais graves problemas de saúde pública enfrentados pelos países em desenvolvimento, onde é endêmica, de difícil controle, com altas taxas de morbidade e mortalidade, e apresentando grande potencial de disseminação entre populações rurais e urbanas (BRUCE-CHWATT, 1985).

Atualmente $40 \%$ da população mundial que habita áreas tropicais e subtropicais vive sob o risco da malária. Estima-se a ocorrência de 300 a 500 milhões de casos clínicos e cerca de 1,5 a 2,7 milhões de óbitos a cada ano. A maioria dos casos ocorre na África ( $80 \%$ de morbidade e $90 \%$ de mortalidade), atingindo principalmente crianças abaixo de cinco anos de idade. Grandes áreas da Ásia, América Central e América do Sul contribuem consideravelmente com estes números (WHO, 1996b).

Nas Américas, 21 países apresentam transmissão ativa da doença: Brasil, Bolívia, Peru, Suriname, Guiana Francesa, Colômbia, República Dominicana, Belize, Costa Rica, El Salvador, Equador, Argentina, Paraguaia, Haiti, Honduras, México, Nicarágua, Panamá, Guatemala, Honduras e Venezuela (PAHO, 1998).

O Brasil apresenta o maior número de casos, $36 \%$ da incidência total nas Américas (PAHO, 1998). Em 2000 foram registrados 615.245 casos, sendo que 613.239 ocorreram na Amazônia Legal. A distribuição dos casos por espécie, neste mesmo ano, demonstrou um predomínio de $P$. vivax (481.655 casos), seguido de $P$. falciparum (125.917) e P. malariae (937) (FUNASA, 2003). 


\section{A Malária no Estado de São Paulo}

A malária esteve presente no Estado de São Paulo desde os períodos iniciais de desenvolvimento sócio-econômico, ligada aos processos de ocupação do território decorrente das atividades extrativistas e agrícolas.

No início da colonização até meados do século XVIII, o crescimento demográfico foi lento e provavelmente a malária ocorria de forma epidêmica. Entretanto, no início do século XX com a expansão da cultura cafeeira, os processos de desmatamento, ocupação de território, construção de ferrovias, associados aos intensos fluxos migratórios internos e externos possibilitaram a instalação de quadros endêmicos da doença, sendo freqüentes as referências de casos neste periodo (BARATA, 1998).

Nas décadas de 40 e 50 a malária era considerada um grave problema de saúde pública no Estado, pois a estabilização do quadro endêmico gerou drásticas quedas na produção associada à significativa redução da capacidade de trabalho. A região Oeste (Planalto Ocidental) apresentava a maior prevalência da doença. Neste período se alicerçaram os estudos epidemiológicos assim como as primeiras intervenções de controle e vigilância que fundamentaram o modelo Técnico Campanhista, culminando com a Campanha de Erradicação da Malária, a qual abrangeu todos os Estados que apresentavam a doença entre as décadas de 60 e 70 (BARATA,1998).

O êxito da Campanha e as modificações ambientais que ocorreram ao longo do tempo, principalmente a devastação das matas em função da atividade agrícola e pecuária, diminuíram drasticamente as densidades de anofelinos, o que tornou inviável a manutenção dos quadros endêmicos da doença.

Desde o final da década de 60, a maioria dos casos de malária que ocorre no Estado de São Paulo são importados da região Amazônica, sendo reduzido o número de casos induzidos e autóctones (SUCEN, 1995).

Apesar do baixo número de casos, a malária se mantém presente em algumas áreas da Mata Atlântica Paulista, onde ocorrem anualmente casos autóctones com sintomatologia atípica diagnosticados como $P$. vivax. Surtos epidêmicos importantes ocorreram em algumas áreas do Planalto Ocidental (Presidente Epitácio, 1980 e 84; 
Panorama, 1984) (SUCEN, 1995). De modo geral, verificamos que a malária não está ausente em nosso Estado, sendo que a ocorrência de casos está associada a situações epidemiológicas particulares, como no caso do quadro da malária autóctone da Mata Atlântica que ainda não está completamente elucidado, e alguns estudos sugerem a participação de macacos no ciclo de transmissão (CURADO et al., 1997).

\section{Malária Humana e Simiana: Similaridades e Aspectos Epidemiológicos}

\subsection{Plasmódios Simianos e Seus Hospedeiros Naturais}

Foram descritas vinte espécies de plasmódio que infectam primatas não humanos. Dentre estas vinte, oito infectam os "grandes macacos" (Família Pongidae): P. schwetzi, P. reichenowi; P. pitheci, P. silvaticum, P. hylobati, $P$. eylesi, $P$. youngi e $P$. jefferyi; e duas espécies infectam os lêmures, ancestrais mais remotos dos primatas (prossímios), $P$. lemuris e $P$. girardi. As dez espécies restantes possuem características biológicas muito semelhantes aos plasmódios humanos. Oito infectam macacos do Velho Mundo (família Cercopithecidae): $P$. cynomolgi, $P$. gonderi, $P$. coatneyi, $P$. fragile, $P$. fieldi, $P$. simiovale, $P$. inui e $P$. knowlesi; e duas infectam macacos do Novo Mundo (famílias Cebidae e Atelidae): P. brasilianum e P. simium (Collins, 1988; Duarte 1998) (Tabela 1).

Algumas destas espécies são amplamente utilizadas em estudos experimentais. Os plasmódios simianos da Ásia e África se desenvolvem em um grande número de espécies de primatas do Velho Mundo e somente em um pequeno número de macacos do Novo Mundo foram conseguidas infecções experimentais com os mesmos (gêneros: Aotus, Cebus, Saimiri, Callithrix). Os modelos experimentais mais utilizados para os plasmódios simianos do Novo Mundo são: macacos dos gêneros Alouatta, Aotus, Ateles, Cebus, Lagothrix, Saimiri, Callithrix e Saguinus, para o P. simium, e macacos dos gêneros Aotus, Callithrix e Saguinus, para o $P$. brasilianum (Collins, 1988). 
As quatro espécies de plasmódio que infectam o homem ( $P$. falciparum, $P$. vivax, $P$. malariae e $P$. ovale), são igualmente utilizadas em estudos sobre imunologia da malária e quimioterapêutica, em um número limitado de macacos. Para o estudo da malária humana alguns gêneros do Novo Mundo são considerados bons modelos experimentais (para $P$. falciparum e $P$. malariae - gênero Aotus; $P$. vivax - gêneros Aotus, Ateles, Saimiri e Saguinus) (Collins, 1988).

Como modelos biológicos comparáveis ao $P$. falciparum são utilizados o $P$. coatneyi e $P$. fragile. Para $P$. ovale são utilizados o $P$. simiovale e o $P$. fragile. Para $P$. malariae são utilizados o $P$. brasilianum e o $P$. inui. Finalmente, para $P$. vivax utilizam-se o $P$. cynomolgi, o $P$. gonderi e o $P$. simium. O $P$. knowlesi, com peculiar ciclo esquizogônico de 24 horas, é considerado como um bom modelo biológico quando os principais critérios analisados são infecção fulminante e morte (Collins, 1988).

O ciclo de vida dos plasmódios simianos é essencialmente igual ao dos parasitos humanos. Até onde se sabe, todos são transmitidos por mosquitos do gênero Anopheles. Os mosquitos injetam esporozoítos infectantes nos primatas, que ao chegarem no fígado dão origem ao ciclo exoeritrocítico. Nesta fase, em algumas espécies ocorrem formas persistentes, que são responsáveis por recaídas (reaparecimento da parasitemia derivada do desenvolvimento secundário de esquizontes no fígado). Esse fenômeno foi observado em $P$. cynomolgi, $P$. fieldi e $P$. simiovale. A duração do ciclo exoeritrocítico é variável dentre as espécies de plasmódio, sendo o menor deles observado em $P$. knowlesi, que completa seu desenvolvimento em aproximadamente 112 horas; outros podem demorar mais dias para adquirir maturidade e liberar merozoítos na circulação. $O$ período pré-patente (tempo entre a infecção e a primeira detecção dos estágios sangüíneos) é também bastante variável entre espécies. Após o início do estágio sangüíneo, os parasitos completam o ciclo assexuado em 24,48 ou 72 horas; sendo a periodicidade denominada como cotidiana, terçã e quartã, respectivamente (Collins, 1988).

Infecções crônicas são caracterizadas por períodos parasitêmicos negativos intercalados com períodos moderados ou altos, que ocorrem ciclicamente com crescimento dos intervalos negativos. Algumas infecções desaparecem dentro de poucos meses, mas outras podem persistir por vários anos, como no caso de $P$. inui. 
O estágio sexuado pode iniciar precocemente na infecção, durante ou imediatamente após a fase aguda. Alguns parasitos possuem ciclos que coincidem com os picos de densidade dos anofelinos, o que certamente aumenta a probabilidade dos mosquitos se infectarem com gametócitos. O tempo de desenvolvimento esporogônico dos plasmódios simianos é bastante variável entre as espécies e depende da temperatura específica para cada uma delas. Ocorrem variações quanto à suscetibilidade à infecção e ao desenvolvimento do parasito entre diferentes espécies de anofelinos. Algumas espécies são suscetíveis a certos plasmódios e refratárias a outros. A quantidade de esporozoítos encontrados na glândula salivar também é bastante variável entre as diferentes espécies de anofelinos (Collins, 1988).

As descrições dos ciclos de vida de plasmódios simianos foram realizadas em modelos experimentais, geralmente através de infecções induzidas em macacos esplenectomizados, diretamente com cepas cultivadas "in vitro" ou por picadas de anofelinos infectados em laboratório. Portanto, são poucas as informações a respeito da dinâmica das interações do parasito, do vetor e dos hospedeiros em condições naturais (Duarte, 1998). 
Tabela 1 - Plasmódios simianos, seus hospedeiros naturais e origens geográficas.

\begin{tabular}{|c|c|c|}
\hline $\begin{array}{|lr|}\text { Espécie } & \text { de } \\
\text { Plasmódio } & \\
\end{array}$ & Hospedeiro Natural & Origem Geográfica \\
\hline P. eylesi & Gibão-Hylobates lar & Malásia \\
\hline P. hylobati & Gibão-Hylobates moloch & Leste da Malásia \\
\hline P. jefferyi & Gibão-Hylobates lar & Malásia \\
\hline P. youngi & Gibão-Hylobates lar & Malásia \\
\hline P. schwetzi & $\begin{array}{l}\text { Chimpanzé-Pan troglodytes } \\
\text { Gorila-Gorilla gorilla }\end{array}$ & $\begin{array}{l}\text { Camarões, Serra Leoa } \\
\text { Zaire, Libéria. Rep. Dem. do } \\
\text { Congo }\end{array}$ \\
\hline P. reichenowi & $\begin{array}{l}\text { Chimpanzé- } \\
\text { Pan troglodytes } \\
\text { Gorila-Gorilla gorilla } \\
\end{array}$ & $\begin{array}{l}\text { Camarões, Serra Leoa } \\
\text { Zaire, Rep. Dem. do Congo } \\
\end{array}$ \\
\hline P. pitheci & $\begin{array}{l}\text { Orangotango- } \\
\text { Pongo pygmaeus }\end{array}$ & Leste da Malásia \\
\hline P. silvaticum & $\begin{array}{l}\text { Orangotango- } \\
\text { Pongo pygmaeus }\end{array}$ & Leste da Malásia \\
\hline P. cynomolgi & Macacos do Velho Mundo & $\begin{array}{l}\text { India, Sri Lanka, Assam, Malásia, } \\
\text { Indonésia, Taiwan }\end{array}$ \\
\hline P. gonderi & Macacos do Velho Mundo & Camarões, Zaire \\
\hline P. coatneyi & Macacos do Velho Mundo & Malásia, Filipinas \\
\hline P. fragile & Macacos do Velho Mundo & Sri Lanka, Sul da Índia \\
\hline$P$. fieldi & Macacos do Velho Mundo & Malásia \\
\hline P. simiovale & Macacos do Velho Mundo & Sri Lanka \\
\hline P. inui & Macacos do Velho Mundo & $\begin{array}{l}\text { Sri Lanka, Índia, Taiwan, Malásia, } \\
\text { Indonésia, Filipinas }\end{array}$ \\
\hline P. knowlesi & Macacos do Velho Mundo & Malasia \\
\hline P. girardi & Lêmures & Madagascar \\
\hline P. lemuris & Lêmures & Madagascar \\
\hline P. brasilianum & Macacos do Novo Mundo & $\begin{array}{l}\text { Brasil, Venezuela, Peru, Colômbia, } \\
\text { Panamá }\end{array}$ \\
\hline P. simium & Macacos do Novo Mundo & Brasil \\
\hline
\end{tabular}


O conhecimento sobre os hospedeiros naturais de plasmódios simianos é bastante vasto, abrangendo aspectos da biologia e taxonomia dos grupos de macacos do Velho e do Novo Mundo.

Os primatas neotropicais, também conhecidos como macacos do Novo Mundo, pertencem a Infraordem Platyrrhini. Os Platirrinos possuem as narinas voltadas para os lados, em um nariz achatado e um focinho curto. Notoriamente diferentes, os representantes da Infraordem Catarrhini, que abrangem os macacos do Velho Mundo e os "grandes macacos", possuem as narinas voltadas para baixo em um focinho longo (AURICCHIO, 1995).

Os Catarrinos, macacos do Velho Mundo e os "grandes macacos", estão agrupados atualmente em 3 famílias taxonômicas: a família Cercophitecidae, composta de 15 gêneros de macacos, a família Pongidae ("grandes macacos"), composta de 5 gêneros e a família Hominidae, com o gênero Homo (AURICCHIO, 1995).

Os Platirrinos, macacos do Novo Mundo, estão agrupados em quatro famílias. A família Callitrichidae, composta por 4 gêneros; Cebidae, com 7 gêneros; Atelidae, com 4 gêneros e Callimiconidae, com 1 gênero. Os nomes populares e a distribuição dos gêneros no território brasileiro podem ser observados, respectivamente, na Tabela 2 e na Figura 1. 
Tabela 2 - Primatas brasileiros: famílias, gêneros e nomes populares.

\begin{tabular}{ll}
\hline $\begin{array}{l}\text { Primatas } \\
\text { Família e gênero }\end{array}$ & Nome Popular \\
\hline $\begin{array}{l}\text { Cebidae } \\
\text { Saimiri }\end{array}$ & $\begin{array}{l}\text { Macaco-de-cheiro (mão-de-ouro, boca-preta, } \\
\text { caipussu, gasimiro, sapajou-aurora) }\end{array}$ \\
\hline Cebus & Macaco-prego (macaco-capuchinho, sahi-hu, caí) \\
\hline Aotus & Macaco-da-noite (cuti-cuti, marikiná, duruculi) \\
\hline Callicebus & $\begin{array}{l}\text { Zogue-zogue (uapuça, sauá, sauí, pruapó, } \\
\text { orabassu, zocaio, guigó) }\end{array}$ \\
\hline Pithecia & $\begin{array}{l}\text { Parauacu (macaco-voador, macaco-cabeludo, } \\
\text { saqui) }\end{array}$ \\
\hline Chiropotes & Cuxiú (macaco-preto) \\
\hline Cacajao & $\begin{array}{l}\text { Uacari (preto, cara-negra, mono-feio, carauri), } \\
\text { uacari-branco (bicó, macaco-inglês), uacari- } \\
\text { vermelho }\end{array}$ \\
\hline $\begin{array}{l}\text { Atelidae } \\
\text { Ateles }\end{array}$ & Macaco-aranha, coatá \\
\hline Alouatta & Bugio (gritador), guariba \\
\hline Lagothrix & Macaco-barrigudo, macaco-peludo \\
\hline Brachyteles & Muriqui, mono-carvoeiro \\
\hline Callitrichidae & Sagüi-de-tufos-brancos, sagüi-de-tufos-pretos, \\
Callithrix & sagüi-comum, sagüi-da-cara-branca, \\
Sagüi-da-serra, sagüi-estrela, sagüi-branco, \\
Sagüi-da-cabeça-preta, sagüi-de-Santarém, \\
Mico-estrela
\end{tabular}

Fonte: AURICCHIO, 1995. 


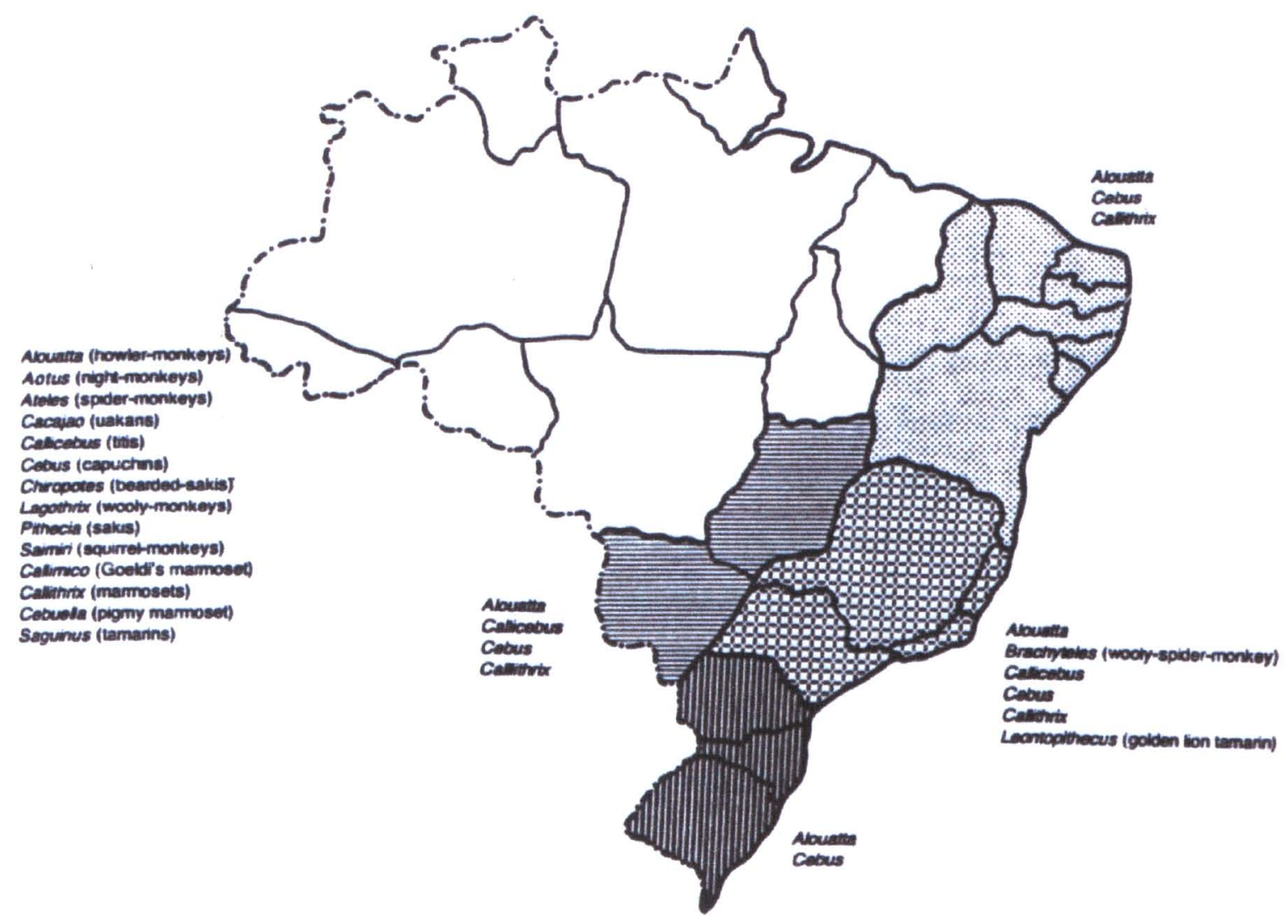

Figura 1 - Distribuição dos gêneros de macacos no território brasileiro. Fonte: DEANE, 1992. 


\subsection{Plasmódios Simianos e Macacos do Novo Mundo}

Em contraste com o número elevado de espécies de plasmódios simianos que infectam macacos da África e Ásia, até hoje somente duas espécies foram encontradas em macacos do Novo Mundo, o P. brasilianum e o P. simium.

\subsubsection{Plasmodium brasilianum (GONDER e VON BERENBERG-GOSSLER, 1908)}

Esta espécie de plasmódio foi encontrada no sangue de um macaco uakari, Cacajao calvus, originário da Região Amazônica, que havia sido enviado para Hamburgo, Alemanha. Foi classificada por Gonder e von Berenberg-Gossler em 1908, que observaram grande semelhança morfológica entre o novo parasito descoberto e o $P$. malariae, causador da febre quartã em humanos.

O parasito possui um ciclo assexuado de 72 horas. As hemácias infectadas não apresentam granulações do tipo Schüffner ou de qualquer outro tipo. $O$ período pré-patente varia entre 18 a 43 dias. Não existem evidências a respeito de recaídas (COLLINS, 1988).

Em estudos experimentais, os níveis parasitêmicos apresentaram-se bastante variáveis entre as espécies de macacos. Em hospedeiros naturais a parasitemia freqüentemente é sub-patente, sendo a infecção considerada inaparente. O $P$. brasilianum é considerado um excelente modelo experimental devido as suas similaridades biológicas com $P$. malariae e por se desenvolver em diferentes macacos do Novo Mundo (COLLINS, 1988).

O vetor natural do $P$. brasilianum nas regiões Sudeste e Sul do Brasil foi identificado como sendo o An. (Kerteszia) cruzii (DEANE et al., 1966; DEANE, 1969b,c; DEANE, 1992). Nas demais Regiões da América onde este parasito ocorre, não foram identificados os vetores competentes na transmissão dos plasmódios simianos. 
Sua distribuição geográfica é ampla, pois foi encontrado na maioria das espécies de macacos da família Cebidae do Panamá (CLARK, 1931; PORTER et al., 1966; BAERG, 1971), Colômbia (MARINKELLE e GROSE, 1968; DUNN e LAMBRECHT, 1963), Venezuela (SERRANO, 1967), Peru (DUNN e LAMBRECHT, 1963) e Brasil (DEANE et al., 1969b,c; DEANE, 1992).

\subsubsection{Plasmodium simium (FONSECA, 1951)}

O P. simium foi encontrado pela primeira vez em um macaco bugio, também conhecido como guariba (Alouatta fusca), proveniente do município de Itapecerica da Serra (SP), em 1939, quando estava sendo realizado um estudo de febre amarela naquela área (FONSECA, 1951).

Posteriormente, o parasito foi encontrado em bugios da região de Mata Atlântica dos Estados de Santa Catarina (DEANE et al., 1969b) e Rio Grande do Sul (DEANE e FERREIRA NETO, 1969b,c); sendo que no Estado do Espírito Santo o parasito foi encontrado também no muriqui, Brachyteles arachnoides (DEANE et al., 1968). Nestes Estados, o vetor natural é também o An. (Kerteszia) cruzii (DEANE et al., 1970).

O parasito possui um ciclo assexuado de 48 horas e foi utilizado como modelo biológico para $P$. vivax e $P$. ovale. As hemácias parasitadas possuem granulações do tipo Schüffner (presentes em $P$. vivax). O período pré-patente varia entre 12 a 38 dias. A parasitemia apresentou-se bastante variável entre as diversas espécies de macacos infectadas experimentalmente (COLLINS, 1988).

Devido às semelhanças biológicas e morfológicas com o $P$. vivax, acredita-se que ocorram recaídas, porém esta hipótese ainda não foi comprovada experimentalmente (COLLINS, 1988).

Foi observado que o ciclo de desenvolvimento do $P$. simium no mosquito é mais longo que o ciclo do $P$. vivax. Também foram feitas algumas tentativas de infecção experimental em voluntários humanos, a partir de formas sangüíneas, porém todas falharam (COATNEY, 1971). 
Pouco se sabe sobre o curso natural da infecção do $P$. brasilianum e do $P$. simium. Em relação aos níveis parasitêmicos, foi observada nas espécies Saimiri sciureus, Ateles paniscus, Lagothrix lagotricha e Alouatta fusca, parasitemia que se apresentou sempre baixa tanto para $P$. simium quanto para $P$. brasilianum, sendo mais persistente neste último. Os sintomas mais comuns foram febre, apatia, perda de apetite e anemia durante a esquizogonia, sendo a recuperação espontânea (DEANE,1992).

\subsection{Dados Epidemiológicos da Malária Simiana no Brasil}

Os dados que dispomos sobre prevalência de malária em macacos brasileiros advêm dos estudos do pesquisador Leonidas de Mello Deane. Seu interesse pelo assunto despertou no final da década de 30 , dentro de pesquisas associadas à Campanha de Erradicação da Malária, quando pôde observar que o $P$. malariae, responsável pela febre quartã benigna humana, era mais prevalente nas regiões de floresta do que em cidades. Este fato, associado às similaridades existentes com o $P$. brasilianum, sugeriu a existência de relação entre as malárias e a possibilidade de macacos agirem como reservatório destes parasitos.

Entre as décadas de 60 e 70, Deane publicou inúmeros trabalhos sobre infecções maláricas em macacos, os vetores envolvidos na transmissão da mesma, e também descreveu o único caso de infecção natural humana por plasmódio simiano no Brasil.

Estes resultados foram agregados em uma revisão bibliográfica publicada em 1992 referentes aos estudos realizados entre 1937 e 1990 por ele e pesquisadores associados (DEANE, 1976; ARRUDA, 1985; LOURENÇO-DE-OLIVEIRA, 1988, 1990 e DEANE et al., 1989).

A metodologia empregada nestes levantamentos foi basicamente análise morfológica dos parasitos por microscopia através de exame de lâmina de esfregaço de sangue e gota espessa. 
Segundo os dados desta revisão, a malária simiana foi freqüente na região Amazônica, onde $10 \%$ dos macacos estavam infectados, sendo a infecção em $99 \%$ dos casos por $P$. brasilianum. O $P$. simium não foi detectado nos macacos da região Norte. Porém, Deane não descartou a possibilidade de ocorrência deste ou de outros plasmódios ainda não identificados, já que em alguns esfregaços não foi possível a identificação. Na Mata Atlântica das regiões Sul e Sudeste, as positividades foram respectivamente, $17,9 \%$ e $35,6 \%$, sendo que no Sul, $P$. simium é o mais prevalente (48,4\%), seguido do $P$. brasilianum (33,3\%); no Sudeste o mais prevalente é o $P$. brasilianum (46,3\%), seguido do $P$. simium (37,5\%). Os macacos da região Nordeste foram negativos para ambos os plasmódios, e os poucos macacos da região CentroOeste incluídos no estudo, apresentaram baixa prevalência para o $P$. brasilianum (Tabela 3) (DEANE, 1992).

Tabela 3 - Plasmódios simianos no Brasil: freqüência de acordo com regiōes, detectados em esfregaços de sangue, 1937-1990ª (Porcentagem entre parênteses).

\begin{tabular}{|c|c|c|c|c|c|c|c|}
\hline Regiões & $\begin{array}{c}\text { Primatas } \\
\text { Examinados }\end{array}$ & $\begin{array}{c}\text { Total cl } \\
\text { Plasmodium }\end{array}$ & $\begin{array}{l}\text { P. brasi } \\
\text { lianum }\end{array}$ & $\underset{\text { simium }}{P .}$ & $\begin{array}{c}\text { P. brasi- } \\
\text { lianumt } \\
P . \\
\text { simium } \\
\end{array}$ & $\begin{array}{c}P . \\
\text { brasi- } \\
\text { lianum } \\
+P . s p \\
\end{array}$ & P. $s p$ \\
\hline Norte & 3.472 & $\begin{array}{c}350 \\
(10,1) \\
\end{array}$ & $\begin{array}{c}347 \\
(99,1) \\
\end{array}$ & - & - & $\begin{array}{c}3 \\
(0,9) \\
\end{array}$ & - \\
\hline Nordeste & 146 & - & - & - & - & - & - \\
\hline Sudeste & 764 & $\begin{array}{c}272 \\
(35,6)\end{array}$ & $\begin{array}{c}126 \\
(46,3)\end{array}$ & $\begin{array}{c}102 \\
(37,5)\end{array}$ & $\begin{array}{c}26 \\
(9,6) \\
\end{array}$ & - & $\begin{array}{c}18 \\
(6,6) \\
\end{array}$ \\
\hline Sul & 184 & $\begin{array}{c}33 \\
(17,9) \\
\end{array}$ & $\begin{array}{c}11 \\
(33,3) \\
\end{array}$ & $\begin{array}{c}14 \\
(48,4) \\
\end{array}$ & $\begin{array}{c}6 \\
(18,2) \\
\end{array}$ & - & $\begin{array}{c}2 \\
(6,1) \\
\end{array}$ \\
\hline $\begin{array}{l}\text { Centro- } \\
\text { Oeste* }\end{array}$ & 67 & $\begin{array}{c}5 \\
(7,5) \\
\end{array}$ & $\begin{array}{c}5 \\
(7,5) \\
\end{array}$ & - & - & - & - \\
\hline Total & 4.585 & $\begin{array}{r}655 \\
(14,3) \\
\end{array}$ & $\begin{array}{c}484 \\
(73,9) \\
\end{array}$ & $\begin{array}{c}116 \\
(17,7) \\
\end{array}$ & $\begin{array}{c}32 \\
(4,9) \\
\end{array}$ & $\begin{array}{c}3 \\
(0,5) \\
\end{array}$ & $\begin{array}{c}20 \\
(3,0) \\
\end{array}$ \\
\hline
\end{tabular}

a: de DEANE, 1976; ARRUDA, 1985; LOURENÇO-DE-OLIVEIRA, 1988, 1990; DEANE et al. 1989.

* Região Centro-Oeste: acrescentado os dados referentes a esta região, descritos nos trabalhos de DEANE e FERREIRA NETO (1973) e TAUIL (1980).

FONTE: DEANE, 1992. 
Em relação à distribuição dos plasmódios nos diferentes gêneros de macacos brasileiros foi observada uma maior prevalência tanto do $P$. brasilianum quanto $o P$. simium no gênero Alouatta. O P. brasilianum foi encontrado em todos os gêneros de macacos, exceto em Aotus, enquanto $P$. simium somente em Alouatta e Brachyteles (DEANE, 1992).

$\mathrm{O}$ vetor associado à transmissão da malária simiana nas Regiões Sul e Sudeste é o Anopheles (Kerteszia) cruzii, que desenvolve suas fases larvais nos verticilos das bromélias, plantas extremamente abundantes na Mata Atlântica. Este vetor possui também uma característica muito peculiar, a distribuição vertical, permitindo que os anofelinos se alimentem tanto no nível do solo quanto na copa das árvores. Na região Amazônica foram conduzidos estudos na tentativa de verificar qual o principal vetor da malária simiana, porém os dados obtidos foram considerados inconclusivos (DEANE et al., 1970, 1971; DEANE,1992).

Em um trabalho realizado no Estado de Goiás por DEANE e FERREIRA NETO (1973), foram examinados 37 animais de três espécies diferentes (Callithrix penicillata, Cebus apella libidinosus e Alouatta caraya) provenientes de sete Municípios, dos quais três bugios (guaribas) da espécie Alouatta caraya, apresentaram $P$. brasilianum no esfregaço; estes oriundos do Município de Monte do Carmo, no Vale do Rio Tocantins. As capturas de mosquitos realizadas no local de origem dos espécimes positivos foram insuficientes para indicar possíveis vetores da malária simiana. Foi a primeira vez que se assinalou malária simiana em uma região de cerrado, que, interessantemente, difere dos demais focos enzoóticos brasileiros descritos na Floresta Amazônica e Mata Atlântica. Alguns anos depois, no Município de Porto Nacional, foram encontrados bugios infectados com $P$. brasilianum naquela região (TAUIL, 1980). Estes resultados não foram incluídos na revisão de DEANE (1992), no entanto estão demonstrados na Tabela 3. 


\subsection{Similaridades e Homologias Parasitológicas e Imunológicas}

Do ponto de vista morfológico e biológico, o $P$. brasilianum é muito semelhante ao $P$. malariae (COATNEY, 1971; DEANE, 1992) e o $P$. simium ao $P$. vivax (FONSECA, 1951; SEED et al., 1976; DEANE, 1992).

$\mathrm{Na}$ literatura foram descritos somente dois casos de infecções naturais humanas causadas comprovadamente por plasmódios simianos.

$O$ primeiro ocorreu em um soldado americano que se infectou com $P$. knowlesi durante missão nas florestas da Malásia (CHIN et al., 1965). Posteriormente, WARREN (1970) descreveu o ciclo zoonótico do mesmo, veiculado através de An. maculatus e An. balabacensis introlatus, ressaltando o risco de infeç̧ão a que se expunham os seres humanos que penetrassem na referida região.

$O$ segundo caso ocorreu em um guarda florestal que contraiu o $P$. simium durante trabalhos de captura entomológica de $A n$. (Ker.) cruzii nas matas da Serra da Cantareira, SP. O paciente apresentou baixa parasitemia e febre do tipo terçã, recusou medicação específica, querendo colaborar com a pesquisa e seu quadro evoluiu em poucos dias para cura espontânea (DEANE et al. 1966; DEANE, 1992).

A transmissão experimental de plasmódios simianos em humanos foi conseguida pela primeira vez em 1932, na Ásia, através da inoculação de sangue infectado com $P$. knowlesi (KNOWLES e DAS GUPTA, 1932). RODHAINI (1940), após concluir que o chimpanzé Pan troglodytes era o reservatório natural do $P$. malariae, conseguiu com sucesso a inoculação experimental no homem.

A transmissão experimental de $P$. brasilianum foi realizada com sucesso por CONTACOS et al. (1963) em 9 voluntários, que desenvolveram a infecção, porém apresentando baixas parasitemias.

MOST (1973) induziu experimentalmente uma infecção por $P$. cynomolgi (parasito de macaco Rhesus) em voluntário humano, que apresentou sintomas brandos que foram gradualmente eliminados por administração de cloroquina.

São inúmeros os estudos que demonstraram a existência de reações sorológicas cruzadas entre antígenos de plasmódios humanos e simianos. 
TOBIE et al. (1962) observaram em Imunofluorescência Indireta (IFI), reações cruzadas quando soros humanos positivos para $P$. vivax foram testados com antígenos de $P$. cynomolgi.

COLLINS et al. (1966), através da reação de Imunofluorescência Indireta, observaram ocorrência de reações cruzadas entre antígeno de $P$. brasilianum e soros de indivíduos infectados com $P$. malariae.

Em um estudo soroepidemiológico conduzido em populações da Nigéria, THOMAS et al. (1981) observaram alta prevalência de anticorpos anti- $P$. brasilianum, em crianças, através das técnicas de IFI e ELISA.

Foi realizado um estudo semelhante no Estado do Pará em duas tribos de índios ao longo do Rio Xingu por ARRUDA et al. (1989), onde a prevalência de anticorpos contra formas sangüíneas de $P$. brasilianum e P. falciparum foi alta na população humana, e surpreendentemente também, nos macacos mantidos como animais de estimação e em macacos selvagens capturados próximo aos locais estudados. $P$. brasilianum foi detectado em lâminas de esfregaço de dois espécimes de macacos do gênero Alouatta e de dois do gênero Ateles. Estes dados sugeriram interação zoonótica naquele local.

\subsection{Proteína Circumsporozoíta (CS) e as Relações entre os Plasmódios Simianos e Humanos.}

O esporozoíto, forma infectante dos plasmódios, é uma célula uninucleada decorrente do amadurecimento de um oocisto, estágio multinucleado que se desenvolve no tubo digestivo dos anofelinos. Os esporozoítos após romperem um oocisto maduro, são carregados através da hemolinfa para a glândula salivar onde permanecem até o momento do repasto sangüíneo, durante o qual são introduzidos no organismo do hospedeiro. Após atingirem os hepatócitos geram milhares de merozoítos que invadirão as hemácias iniciando o ciclo eritrocítico (MÉNARD, 2000). 
Três moléculas foram identificadas especificamente no esporozoíto: a proteína circumsporozoíta (CS) (DAME et al., 1984; ENEA et al., 1984), TRAP ("thrombospondin related anonymous protein") (ROBSON et al., 1988) $\mathrm{e}$ "sporozoite threonine and aspargine-rich protein" (FIDOCK et al.,1994). A CS e a TRAP, que foram mais estudadas até o momento, participam dos processos de desenvolvimento do esporozoíto e de invasão dos mesmos nos hepatócitos (MÉNARD, 2000).

A proteína circumsporozoita (CS) recobre a maior parte da membrana dos esporozoítas maduros (NUSSENZWEIG e NUSSENZWEIG, 1984).

VANDERBERG et al. (1969) observaram que esporozoítos imaturos encontrados no intestino médio de mosquitos vetores possuem pouca ou nenhuma CS em suas membranas, o que indica a existência de uma correlação temporal entre a aquisição de infectividade e o aparecimento da CS na membrana do parasito.

A incubação dos esporozoítos com soros ou anticorpos monoclonais provoca a chamada Reação de Precipitação Circumsporozoíta (VANDERBERG et al., 1969; NUSSENZWEIG et al., 1973), sendo que estudos de microscopia eletrônica confirmaram que o antígeno envolvido nesta reação está uniformemente distribuído ao longo da superfície da forma infectante (COCHRANE et al., 1976).

Sua estrutura apresenta uma região terminal altamente conservada entre as espécies e uma região central composta de aminoácidos repetitivos (epítopos imunodominantes) (ARNOT et al., 1985; McCUTCHAN et al., 1985; MÉNARD, 2000).

Sabemos hoje que a proteína CS difere entre as espécies de plasmódios e mesmo dentre os isolados geográficos de uma mesma espécie, sendo esta última situação observada em $P$. vivax, que apresenta variações tanto na região repetitiva quanto na região conservada. As diferenças referem-se ao tamanho, seqüência e número de regiões repetitivas de aminoácidos (KEMP et al., 1987; QARI et al.,1991, 1992; MANN et al., 1994, 1995).

A diversidade gênica e antigênica da proteína CS de $P$. vivax e $P$. falciparum foi extensivamente estudada, em função da sua possível utilização em vacinas antimaláricas (LOCKYER e SCHWARZ, 1987; QARI et al., 1992) 
Foram descritas até o momento quatro diferentes composições de aminoácidos da região repetitiva da proteína CS de $P$. vivax: o $P$. vivax "clássico" (VK210), o $P$. vivax variante (VK247), o $P$. vivax-like humano/P. simiovale e uma variação encontrada em isolados da Coréia do Sul, sem nomenclatura definida.

A primeira seqüência da região repetitiva da CS descrita foi identificada em três linhagens "Belém", "Sal-1" e "North Korean", denominadas como $P$. vivax "clássico" (VK210) ou Tipo I (GDRA(D/A)GQPA) (ARNOT et al., 1985; McCUTCHAN et al., 1985).

ROSENBERG et al. (1989) estudando casos de pacientes da Tailândia $\operatorname{com} P$. vivax verificaram heterogeneidade fenotípica na região repetitiva da proteína $\mathrm{CS}$, pois esporozoítos obtidos de mosquitos infectados com estas cepas não foram reconhecidos por anticorpos monoclonais contra a proteína CS de diferentes cepas de $P$. vivax e de outras espécies de malária humana e simiana. Esta variante foi chamada então de $P$. vivax VK247, sendo que sua região repetitiva difere em $6 / 9$ aminoácidos [ANGA(G/D)(N/D)QPG] da seqüência do $P$. vivax "clássico" (VK 210), descrita até então [GDRA(D/A)GQPA] (ARNOT et al., 1985; McCUTCHAN et al., 1985).

Através de metodologia semelhante, QARI et al. (1993) identificaram um parasito no sangue de pacientes da Papua Nova Guiné, que é semelhante morfologicamente ao $P$. vivax, porém possui a região repetitiva da proteína CS idêntica àquela de $P$. simiovale [APGANQ(E/G)GGAA], um parasito de macaco Rhesus, morfologicamente semelhante ao $P$. ovale humano. Entretanto, a identidade desse novo parasito não ficou clara, já que não foi obtida uma linhagem isolada de humanos (WARHURST et al., 1993). Não foi comprovado também se $P$. simiovale é infectante para o homem (QARI et al., 1993), como também não está claro se $P$. vivax-like é um membro da espécie $P$. vivax ou um novo parasito de malária humana (OLIVEIRA et al., 1995a).

LIM et al. (2001) encontraram uma quarta variação em cepas obtidas de pacientes da Coréia do Sul que apresentaram infecção por $P$. vivax, porém com períodos pré-patentes mais longos (aproximadamente 1 ano). Ao analisar as seqüências gênica e antigênica da CS dos mesmos, constataram diferença na região conservada posterior, não observada nos demais isolados já descritos (AGGNAANKKAEDAGGNA). 
Atualmente sabemos que as variantes encontram-se amplamente dispersas nas áreas de ocorrência de malária vivax (QARI et al., 1991; QARI et al., 1992; KAIN et al., 1991).

No Brasil, KREMSNER et al. (1992), verificaram a ocorrência de anticorpos contra a variante VK247 em populações do Estado do Acre; posteriormente MARRELLI et al. (1997), detectaram a prevalência contra o $P$. vivax-like humano na mesma área, sendo esta última assinalada também em populações no Estado do Pará por OLIVEIRA et al. (1995b).

No que se refere à proteína CS de $P$. malariae, LAL et al. (1988a,b), observaram que não existe diferença entre a sequiência gênica que codifica a região repetitiva da proteína CS de $P$. malariae e $P$. brasilianum (plasmódio que infecta macacos do Novo Mundo); A região central imunodominante de ambas espécies consiste em 45 cópias da seqüência repetitiva (NAAG) e 6 cópias da seqüência (NDAG).

COCHRANE et al. (1984) utilizando anticorpos monoclonais contra um epítopo específico da proteína CS do $P$. malariae, já tinham observado que o mesmo anticorpo reconhecia um epítopo semelhante no $P$. brasilianum, mas não reconhecia nenhuma outra espécie de plasmódio. Tal evidência, segundo os autores, reforça a hipótese de COATNEY (1971) segundo a qual $P$. brasilianum seria uma cepa do $P$. malariae que se adaptou aos macacos do Novo Mundo.

De forma semelhante, BARNWELL (1986), observou que anticorpos monoclonais contra a proteína CS de $P$. vivax reagiam com antígeno de $P$. simium, o que lhe também sugeria existir uma proximidade entre estas espécies.

Somando-se a essa última observação, outra similaridade surpreendente foi observada por GOLDMAN et al. (1993). O gene CS de $P$. simium foi amplificado por "primers" de P. vivax. A partir do produto do PCR de aproximadamente $1.2 \mathrm{~Kb}$, foram obtidos 9 clones, dos quais 7 apresentaram sequiência repetitiva CS idêntica ao $P$. vivax clássico (GDRAA/DGQPA) correspondente às linhagens "Belem", "Sal 1" e "North Korean" que designaram como PVCS type 1(old type), e 2 clones que $\begin{array}{lllllll}\text { apresentaram seqüência repetitiva idêntica ao } P \text {. vivax } & \text { VK247 }\end{array}$ (ANGAG/DN/DQPG), designados como PVCS type 2. 
Após a descrição da seqüência do gene que codifica a região repetitiva da proteína CS do $P$. falciparum (DAME et al., 1984), LAL e GOLDMAN (1991) observaram que a região repetitiva da proteína CS de $P$. reichenowi (NVNP), possui grande similaridade com a de $P$. falciparum (NANP e NVDP).

ESCALANTE et al. (1995) fizeram um extenso estudo filogenético nas porções terminais (regiões não repetitivas) do gene que codifica a CS, analisando 12 espécies de plasmódios. Foi constatado que nestas porções $P$. malariae, $P$. vivax, e $P$. vivax-like são indistingüíveis de $P$. brasilianum, $P$. simium e $P$. simiovale, respectivamente. Também foi observada uma grande proximidade filogenética entre $P$. falciparum e $P$. reichenowi, parasito de chimpanzés (Pan troglodytes). De acordo com estes resultados, os autores sugerem que hospedeiros simianos podem servir como reservatório de plasmódios humanos. Também sugerem que as semelhanças entre plasmódios simianos e humanos são fortes indicativos da ocorrência de processos de especiação, ou seja, ao longo do tempo, uma mesma espécie de plasmódio se adaptou em dois hospedeiros diferentes.

Essas hipóteses corroboram com aquela proposta por COATNEY em 1971, onde ele sugeriu que o $P$. vivax e o $P$. malariae foram transmitidos para os macacos do Novo Mundo quando humanos chegaram às Américas.

Um melhor conhecimento dos plasmódios simianos possibilitará também uma nova organização do gênero Plasmodium, já que tantas evidências nos mostram hoje a proximidade evolutiva entre as várias espécies até então consideradas (WATERS, 1993; ESCALANTE et al., 1995).

LAL et al. (1988b), fazem uma interessante abordagem deste assunto. Consideram que, embora a presença de reservatórios animais seja provavelmente insignificante em termos de saúde pública, poderia exercer efeitos danosos no caso de administração de vacina anti-malárica em regiões de floresta onde homens e macacos estão presentes. Caso a distribuição destes reservatórios simianos seja maior que o atualmente esperado, e realmente ocorram situações epidemiológicas de interação entres as malárias, a dinâmica da vacinação, o controle e a erradicação poderiam ser afetados. 
Um estudo epidemiológico tentando compreender estas relações foi conduzido no Gabão, em áreas de ocorrência de $P$. falciparum e $P$. malariae, habitadas por chimpanzés, gorilas (macacos do Velho Mundo) e população humana. Os resultados dos exames parasitológicos (esfregaço e "PCR") nos macacos foram negativos. Na sorologia foram detectados macacos positivos com anticorpos contra CS de $P$. falciparum e na Imunofluorescência Indireta (IFI), uma prevalência muito baixa para anticorpos contra formas sanguíneas. Em função destes resultados os autores concluíram que a situação epidemiológica da malária humana naquela área não parecia ter a participação de macacos atuando como reservatórios (OLLOMO et al., 1997).

A presença de anticorpos contra proteína CS, MSP1, SPf66 de $P$. falciparum foi observada em macacos (Saimiri sciureus macrodon) capturados na floresta amazônica do Peru (GOZALO et al., 1997). A resposta para CS indica o contato com mosquitos infectados com esporozoítos de $P$. falciparum. $O$ antígeno recombinante MSP1 representa parte de uma proteína dos merozoítos altamente conservada entre as diversas cepas já isoladas de P. falciparum (BLACKMAN et al., 1990). O antígeno SPf66 também está presente em formas assexuadas, portanto os resultados observados neste trabalho indicam também a ocorrência da infecção por $P$. falciparum. Os autores discutem a possibilidade de ocorrência de casos assintomáticos, já que nenhum dos macacos apresentou sinais de malária.

No Brasil alguns estudos sobre malária autóctone humana foram conduzidos em regiões da Mata Atlântica, onde humanos, macacos e vetores estão presentes.

CAMARGO (1992) estudou casos de "malária vivax" autóctone no sul do Estado de São Paulo e aventou a possibilidade da ocorrência de plasmódios simianos ou mesmo de $P$. malariae ao homem em uma condição silenciosa, não detectável por meio da técnica hemoscópica (gota espessa), que deixa a desejar em termos de especificidade, principalmente em casos de baixas parasitemias (LÓPEZANTUÑANO e SCHUMIS, 1988).

CURADO et al. (1997) realizaram estudos sorológicos em populações da Serra do Mar e Vale do Ribeira, Estado de São Paulo, verificando alta prevalência de anticorpos contra proteína CS de $P$. vivax-like humano/P. simiovale e $P$. malariae/ $P$. brasilianum, e também contra formas sangüineas de $P$. vivax e $P$. malariae. Estes 
dados associados à presença de vetores competentes para transmissão de plasmódios simianos e humanos, An. (Kerteszia) cruzii, e a ocorrência de poucos casos sintomáticos, reforçam a hipótese de relação entre as malárias humana e simiana nas áreas de Mata Atlântica.

Em região de cerrado, DEANE e FERREIRA NETO (1973) detectaram pela primeira vez $P$. brasilianum em bugios no Estado de Goiás. Posteriormente, TAUIL (1980) também detectou o mesmo parasito em bugios no município de Porto Nacional.

Em amostras de soro de bugios capturados na área do reservatório da UHE de Serra da Mesa (Goiás) verificou-se alta prevalência de anticorpos contra CS de $P$. vivax e suas variantes, $P$. malariae/P.brasilianum e $P$. falciparum, e em menor proporção, respostas contra formas sangüineas de $P$. vivax, $P$. malariae e $P$. falciparum. Os exames parasitológicos (gota espessa/esfregaço e PCR) foram negativos, entretanto as evidências sorológicas sugeriram ocorrência de episódios passados de malária nos macacos daquela região (DUARTE, 1998).

As pesquisas mais recentes sobre o assunto foram realizadas em área de Floresta Amazônica, na Guiana Francesa, por FANDEUR et al. (2000) e VOLNEY et al. (2002).

FANDEUR et al. (2000) verificaram a presença de $P$. brasilianum em macacos capturados durante a construção de uma UHE no Rio Sinnamary, por exame direto de esfregaço e PCR. Demonstraram também a grande proximidade taxonômica entre $P$. brasilianum e $P$. malariae, corroborando com evidências que indicam se tratar de uma única espécie (LAL et al., 1988a,b; ESCALANTE et al., 1995). Os autores sugeriram que os macacos da região atuam como reservatórios naturais da malária humana e simiana.

Em trabalho posterior, realizaram um estudo soroepidemiológico abrangendo população humana (índios e descendentes de escravos) e macacos da mesma área. Os autores descreveram altos níveis de anticorpos contra formas sangüíneas de $P$. malariae/P.brasilianum, $P$. falciparum e $P$. vivax, e contra proteína CS de $P$. malariae/P. brasilianum, $P$. falciparum, $P$. vivax e suas variantes, ressaltando que os resultados dos bugios foram bastante significativos para a espécie presente naquela 
região, Alouatta senicullus macconenelli, sugerindo também a participação dos mesmos no ciclo de transmissão da malária (VOLNEY et al., 2002).

Apesar de todo conhecimento já acumulado, muitas dúvidas permanecem devido às dificuldades no estudo da doença em macacos silvestres e a conseqüente inexistência de pesquisas que abordem as interações entre malária simiana e humana, nos níveis parasitológico, sorológico e vetorial. Conseqüentemente, ainda não se sabe a real capacidade dos macacos do Novo Mundo atuarem como reservatórios para plasmódios humanos e, portanto, gerarem algum risco de transmissão da malária para populações humanas.

\subsection{Malária, Usinas Hidrelétricas e Impacto Ambiental}

A energia gerada por usinas hidrelétricas apresenta benefícios indiscutíveis no nível qualitativo, pois é limpa, invisível, sem resíduos ou contaminantes, e quantitativo, porque atende a uma grande demanda energética. Em particular, para as condições brasileiras é ideal, já que o país possui uma reserva hídrica de grande magnitude.

Entretanto, apesar de suas atribuições positivas, as usinas hidrelétricas geram inúmeros impactos negativos nos âmbitos ambientais e sócio-econômicos (MÜLLER, 1995).

No que se refere à saúde pública, as populações residentes nas áreas de barragens ficam expostas as enfermidades decorrentes dos diversos tipos de impacto:

- Instabilidades psicológicas e sociais: construção da barragem, contingente de trabalhadores em condições precárias, transferências das famílias para áreas de assentamentos, etc.

- Falta de saneamento ambiental, quanto às condições inadequadas das disponibilidades de água potável, ausência ou má disposição dos esgotos e lixo, viabilizando a ocorrência de enfermidades. 
- Os desequilibrios ambientais que o reservatório promove, afetando diretamente todos os componentes da fauna e flora, especialmente populações de insetos, favorecendo a proliferação de vetores de endemias (MÜLLER, 1995).

Com referência à proliferação de culicídeos, a formação de lagos artificiais contribui de maneira significativa para a elevação das densidades dos mesmos, aumentando consideravelmente o risco de ocorrência de certas doenças (VAN THIEL, 1962; HUNTER et al., 1982; WIJESUNDERA, 1988; ROUDY, 1989; JUNK e NUNES DE MELLO, 1990; DÉGALLIER et al., 1990; MUCCI, 1999).

Grandes reservatórios na África, Ásia e Américas contribuíram para a formação de criadouros de vetores da malária (BAXTER, 1977; COOSEMANS e MOUCHET, 1990; MENEZES, 1997).

No Brasil, foram descritas importantes situações de transmissão de malária associadas à construção de barragens.

Em Tucuruí (Pará), a população residente às margens do lago da usina hidrelétrica (UHE) foi prejudicada com a alta proliferação de Mansonia $s p$ (GOODLAND, 1978) e acrescido ao fato à observação do aumento de casos de malária, sendo $A n$. darlingi a espécie incriminada como principal vetor (TADEI, 1983). Macacos capturados durante o enchimento do reservatório, apresentaram alta prevalência para $P$. brasilianum em exame parasitológico (ARRUDA, 1985).

$\mathrm{Na}$ UHE de Itaipu, foi observada a relação entre o aumento da densidade de An. darlingi e a incidência de casos autóctones, que cresceram paralelamente ao aumento de casos importados na região, principalmente de trabalhadores originários do Estado de Rondônia (CONSOLIM et al., 1991).

Dados obtidos em pesquisas fragmentadas sobre vetores de arboviroses e malária, em outras UHE como Balbina, Cachoeira Porteira, Ji-Paraná e Caruá-Una, confirmaram a ocorrência desequilibrada de culicídeos devido à formação de criadouros ideais, que apresentam águas rasas e quentes, indicando o aumento do risco de ocorrência destas doenças (TEODORO et al., 1995; TADEI, 1983; JUNK e NUNES DE MELO, 1990; DÉGARLIER et al., 1990; TADEI et al., 1998).

LOURENÇO DE OLIVEIRA e DEANE (1995) analisaram lâminas de esfregaço de sangue de macacos de diversos gêneros, capturados nas barragens de 
Balbina (Amazonas) e Samuel (Rondônia) registrando infecção por P. brasilianum nos espécimes analisados.

Mais recentemente, na UHE de Serra da Mesa no Estado de Goiás, 4 trabalhadores da barragem contraíram malária. Esses casos foram considerados autóctones e um estudo anofélico realizado pela FUNASA apontou como prováveis vetores An. albitarsis e An. darlingi (SANTOS et al., 1997). A região apresentou, no passado, quadros focais da doença, associados à migração de garimpeiros de zonas endêmicas. A transmissão foi controlada ao longo do tempo, porém a doença reapareceu em decorrência das modificações ambientais ocasionadas pela construção da barragem (comunicação pessoal - Divisão Epidemiológica FUNASA/Goiás). Como descrito no item anterior, amostras de sangue de macacos resgatados durante o enchimento do reservatório de Serra da Mesa foram submetidas a testes sorológicos que evidenciaram a presença de anticorpos contra formas sangüíneas e contra formas infectantes de $P$. vivax e $P$. falciparum (DUARTE, 1998).

Em decorrência dos diversos aspectos dos quadros epidemiológicos discutidos anteriormente, foi despertada a atenção para a UHE de Sérgio Motta, conhecida popularmente como "UHE Porto Primavera", pois as características de seu grande reservatório e a somatória dos efeitos do impacto ambiental gerado pela obra indicam uma situação potencial de instalação de futuros focos de malária (NATAL et al., 1998).

A conhecida malária da barranca do Rio Paraná, que acometeu por vários anos as populações da margem paulista do Rio Paraná, no Município de Presidente Epitácio, e da margem esquerda, no Estado do Mato Grosso do Sul, em período anterior à formação do reservatório, praticamente desapareceu da região em decorrência das mudanças ambientais geradas pelas atividades humanas, principalmente a agricultura e a pecuária, que diminuíram drasticamente as populações de vetores, em concomitante às ações dos programas de controle e vigilância.

No município de Presidente Epitácio o último caso de malária autóctone foi notificado em 1993 (SUCEN, 2002) e os últimos surtos ocorreram em 1980 e 1984 (SUCEN, 1995). No entanto, a pesquisa entomológica conduzida pelo nosso grupo nesta região desde 1997, tem indicado aumento gradativo das densidades de espécies 
vetoras (An. darlingi e An. albitarsis), principalmente nos períodos que sucederam as inundações da UHE, e atualmente, após a estabilização das águas do reservatório (janeiro de 1999, março de 2001), sugerindo o aumento do risco de retorno da malária nesta área.

As informações epidemiológicas de malária na região vizinha, no Estado do Mato Grosso do Sul, são escassas. No entanto, dados gerais da FUNASA indicam uma tendência crescente no número de casos nos últimos cinco anos (casos confirmados: 86 em 1997, 94 em 1998, 63 em 1999, 238 em 2000 e 233 em 2001) (FUNASA 2002).

Em relação à malária simiana, nenhum estudo foi realizado até o momento na região do Planalto Ocidental Paulista. Na revisão bibliográfica de DEANE (1992), somente macacos de áreas de Mata Atlântica Paulista foram estudados, portanto são inexistentes os conhecimentos sobre infecções maláricas em macacos nesta região ou em áreas de transição para o Pantanal, no Estado do Mato Grosso do Sul.

A elucidação das relações epidemiológicas entre os plasmódios humanos e simianos e seus reservatórios é de crucial interesse, já que semelhanças biológicas entre os mesmos indicam se tratar de espécies homólogas. Comprovando a existência de quadros peculiares onde exista uma interação entre a malária humana e simiana, medidas de controle e vigilância deverão ser reformuladas. Adicionalmente, com os avanços das técnicas de biologia molecular, novos parasitos ou mesmo novas linhagens poderão ser identificados, implementando assim os conhecimentos de filogenia e demonstrando a real distribuição de plasmódios simianos no território brasileiro. 


\section{OBJETIVOS}

Aproveitando a oportunidade da construção da UHE de Porto Primavera e a conseqüente formação do reservatório, que atingiu uma área com história de malária humana no Município de Presidente Epitácio, e o concomitante resgate de animais silvestres nas regiões inundadas; o presente estudo teve como objetivo geral investigar aspectos epidemiológicos da malária humana e simiana e o potencial de envolvimento de bugios (Alouatta caraya) no ciclo de transmissão da doença.

\section{OBJETIVOS ESPECÍFICOS}

1) Verificar a ocorrência de anticorpos da classe IgG contra peptídeos sintéticos que mimetizam a região repetitiva da proteína CS de $P$. vivax "clássico" (VK210) ou Tipo I; $P$. vivax variante (VK247) ou Tipo II, $P$. vivax-like humano/P. simiovale, $P$. malariae/P. brasilianum e $P$. falciparum, por meio de reação de ELISA; nos soros dos habitantes das margens do reservatório e nos soros de bugios (Alouatta caraya) capturados em áreas adjacentes. Com isso, observar em ambas as populações resposta imunológica contra esporozoítos de plasmódio.

2) Verificar a ocorrência de anticorpos da classe $\operatorname{IgG}$ contra formas sangüíneas (assexuadas) de $P$. vivax, $P$. falciparum e $P$. malariae, por meio de reação de Imunofluorescência Indireta (IFI), nos soros dos habitantes das margens do reservatório e nos soros de bugios (Alouatta caraya) capturados em áreas adjacentes. Com isso, observar em ambas as populações resposta imunológica à infecção malárica. 
3) Verificar possíveis diferenças nas prevalências dos anticorpos na amostra da população humana, segundo o sexo, faixa etária, tipo de ocupação e tempo de residência na área.

4) Verificar possíveis diferenças nas prevalências dos anticorpos na amostra de bugios, em grupos definidos por sexo e faixa etária.

5) Detectar a ocorrência de infecção por plasmódios nas amostras de sangue de humanos e macacos por meio dos seguintes métodos:

- Exame parasitológico do sangue periférico (esfregaço e gota espessa).

- Reação de Polimerização em Cadeia (PCR) com "primers" que amplificam sequiência gênero-específica da região $18 \mathrm{~S}$ do rRNA de plasmódio; e "primers" correspondentes à seqüência completa do gene da proteína CS de $P$. vivax, $P$. malariae e $P$. falciparum. 


\section{MATERIAIS E MÉTODOS}

\section{1. Área de Estudo}

A área de estudo situa-se à margem esquerda do lago formado pelo represamento do Rio Paraná, na região do reservatório da Usina Hidrelétrica (UHE) Engenheiro Sérgio Mota, conhecida popularmente como UHE Porto Primavera, no Município de Presidente Epitácio, oeste do Estado de São Paulo (52 06 '12”'W / $21^{\circ} 45^{\prime} 34^{\prime \prime}$ ). Limita-se ao norte pelo rio do Peixe, ao sul pelo córrego do Veado, a leste pelo córrego Água Sumida e a oeste pelo rio Paraná. O reservatório dista aproximadamente $100 \mathrm{Km}$ da barragem, que se localiza no município de Porto Primavera (Figura 2).

A vegetação caracteriza-se como fragmento de Floresta Estacional Semidecidual (FUNDAÇÃO IBGE, 1998), e apresenta clima do tipo Aw-Tropical de Inverno Seco, segundo o sistema de classificação de Köeppen, atingindo temperaturas médias entre $19^{\circ} \mathrm{C}$ e $26^{\circ} \mathrm{C}$, nos meses frios e quentes, respectivamente. A precipitação média anual oscila entre 1000 e $1400 \mathrm{~mm}$, com a média do mês mais seco não excedendo os $30 \mathrm{~mm}$ de chuva (ALENCAR et al., 1976; PAULA, 2001).

Os solos são do tipo Latossolo Vermelho-Escuro/fase arenosa (LEa), de pouca capacidade de infiltração das águas de chuva (ALENCAR et al., 1976; PAULA, 2001).

A área de interesse compreende as partes de várzea da margem esquerda do reservatório, que no passado corresponderam à planície de inundação do rio Paraná e apresentavam extensa mata ciliar com presença de grande diversidade faunística, destacando-se populações de macacos. As populações humanas estabeleceram-se nos ambientes terrestres mais altos adjacentes, fora da zona de influência fluvial direta (ALENCAR et al., 1976; NATAL, 2001). 


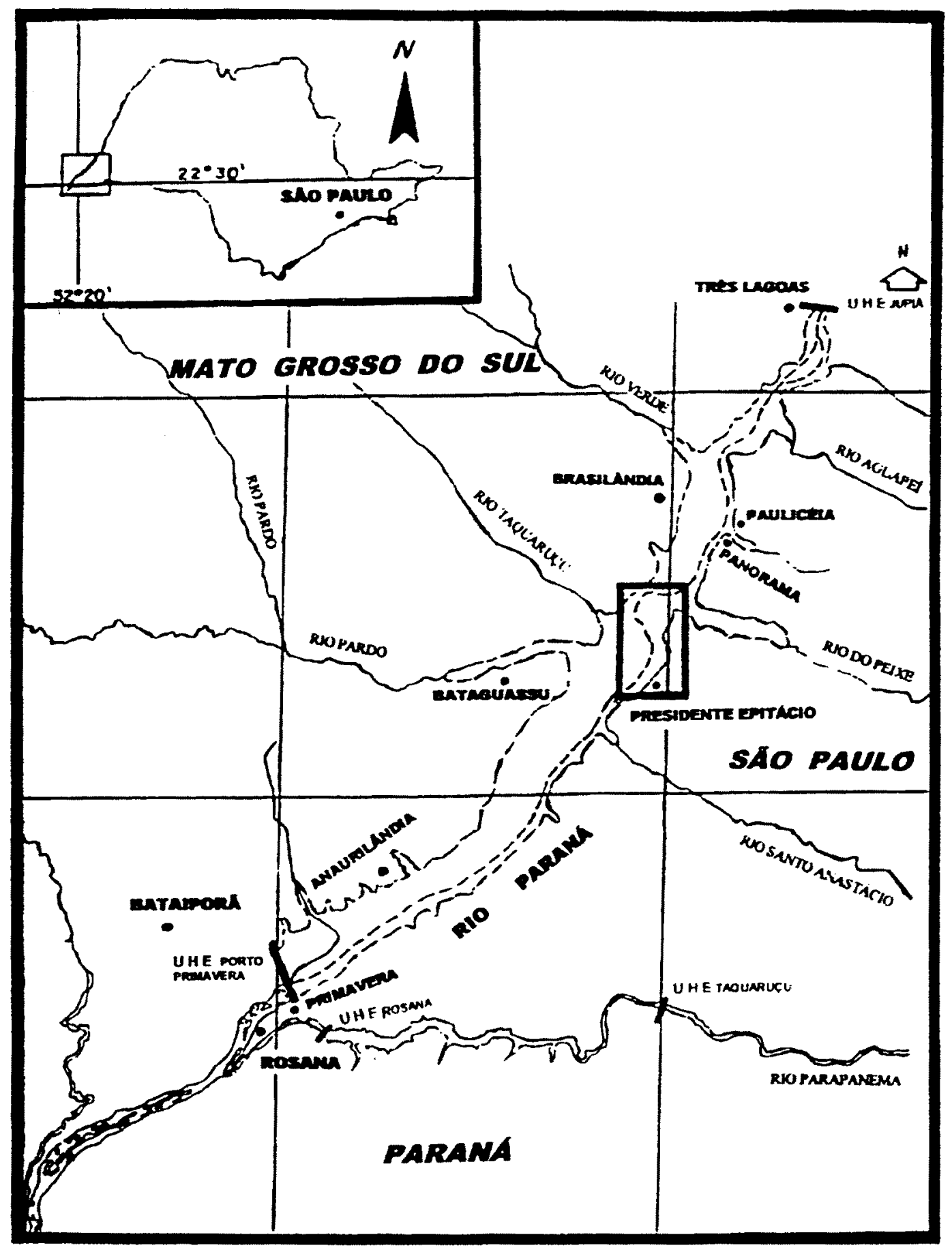

Figura 2 - Localização da UHE Porto Primavera e da área de estudo (retângulo), em relação ao Estado de São Paulo, sobre croqui cedido pela Companhia Energética de São Paulo (CESP).

Fonte: PAULA, 2001. 
Estes ambientes compunham uma área de preservação que, em época anterior ao enchimento, era denominada Reserva Biológica da Lagoa São Paulo $\left(52^{\circ} 05^{\prime} \mathrm{W} / 21^{\circ} 47^{\prime} \mathrm{S}\right)$, iniciava-se ao sul nas proximidades da cidade de Presidente Epitácio e ao norte expandindo-se além da desembocadura do rio do Peixe, cuja via de acesso é a estrada asfaltada que liga a sede do Município ao distrito rural do Campinal (NATAL, 2001).

A população humana ocupa duas áreas distintas: Campinal e Reassentamento Lagoa São Paulo (RLSP).

O Campinal é habitado em sua maioria por nativos da região. No ano de 2000 a população totalizava 2.476 habitantes, segundo dados do Censo da Fundação IBGE (IBGE, 2000).

A região apresenta história passada de malária autóctone associada às épocas de cheia do Rio Paraná, conhecida popularmente como "malária da barranca do rio", que teve declínio no quadro de transmissão a partir de 1970. Os últimos surtos ocorreram em 1980 e 1984 (SUCEN, 1995), e os últimos casos autóctones em 1990 e 1993 (SUCEN, 2002).

As inundações do reservatório, ocorridas em dois periodos: janeiro de $1999 \mathrm{e}$ março de 2001, não atingiram diretamente esta área; entretanto alguns pontos do Campinal distam apenas alguns metros das novas margens que se formaram após o último enchimento.

O RLSP, vizinho ao Campinal, foi construído em 1980 sendo formado por 5 agrovilas. Reassentou inicialmente 516 familias que habitavam as áreas de várzea da antiga Reserva Biológica da Lagoa São Paulo e ilhas do rio Paraná, áreas que atualmente estão submersas.

Devido ao atraso na construção da UHE, inúmeros posseiros e grupos de "sem-terra" invadiram, ao longo do tempo, áreas desocupadas do RLSP. Em função desta situação, a população da área é bastante heterogênea no que se refere à procedência dos indivíduos e tempo de permanência dos mesmos na área. Existem familias que moram no reassentamento há muitos anos e outras que chegaram há pouco tempo. Não foram encontrados dados populacionais específicos da área do Reassentamento. 


\section{Inquérito Epidemiológico, Definição da Amostra e Coleta de Sangue da População Humana}

Considerando as relevantes diferenças no perfil das duas localidades, Campinal e RLSP, foi realizado um censo em setembro de 1999 com o intuito de obter dados mais precisos sobre as comunidades da área de estudo. Foram considerados neste inquérito apenas residentes maiores de 15 anos.

Esta atividade contou com a colaboração da equipe técnica da Secretaria Municipal de Saúde, funcionários da CESP e funcionários do Serviço de Controle de Vetores da Prefeitura de Presidente Epitácio.

Foram entrevistadas 861 pessoas que espontaneamente manifestaram interesse em participar do inquérito. Os dados destas pessoas foram descritos em uma Ficha de Investigação (Anexo 1). A amostra para a coleta de sangue foi calculada a partir deste número, resultando em 196 indivíduos, tendo sido adotados $5 \%$ de erro de $1^{\mathrm{a}}$ espécie e $20 \%$ de erro de segunda espécie; considerando uma possível recusa de $10 \%$, a amostra passou a ser 216 indivíduos.

Por meio de uma amostragem casual sistemática, realizou-se sorteio das 216 fichas, com intervalo amostral de tamanho 4, através do programa SPSS.

Um banco de dados foi ordenado no programa Excell considerando as variáveis presentes na ficha de investigação: nome, idade, sexo, tempo de residência, tempo de permanência, etc.

O projeto de pesquisa bem como o Termo de Consentimento (Anexo 2) foram avaliados e aprovados pela Comissão de Ética desta Instituição em 25 de junho de 1999, Of. COEP/89/99 (Anexo 3).

Em janeiro de 2000, após explicação dos objetivos da pesquisa e a subseqüente autorização de cada indivíduo que concordou em participar da mesma as amostras de sangue dos 216 indivíduos sorteados (130 residentes do Campinal e 86 do RLSP) foram coletadas por enfermeiras da Secretaria Municipal de Saúde, sob nossa supervisão. 
Foram coletadas amostras de sangue venoso em tubos "Vacutainer" com e sem anticoagulante (EDTA) de cada indivíduo. Concomitantemente foram preparadas lâminas de esfregaço e de gota espessa de cada amostra. As mesmas foram acondicionadas em porta-lâminas.

As amostras de sangue foram transportadas em gelo até o Laboratório de Epidemiologia da Faculdade de Saúde Pública, onde foram centrifugadas para separação das hemácias (para extração de DNA) e dos soros (reações de ELISA e Imunofluorescência Indireta). As hemácias, assim como os soros, foram congelados à $-20^{\circ} \mathrm{C}$, sendo que em cada amostra de soro foi acrescentada glicerina tamponada (volume/volume) antes do congelamento.

A distribuição dos domicilios da população humana amostrada e dos locais de captura dos macacos está representada, respectivamente, por pontos azuis e vermelhos (Figura 3), cujas posições geográficas foram adquiridas com um receptor GPS (Global Position System). 


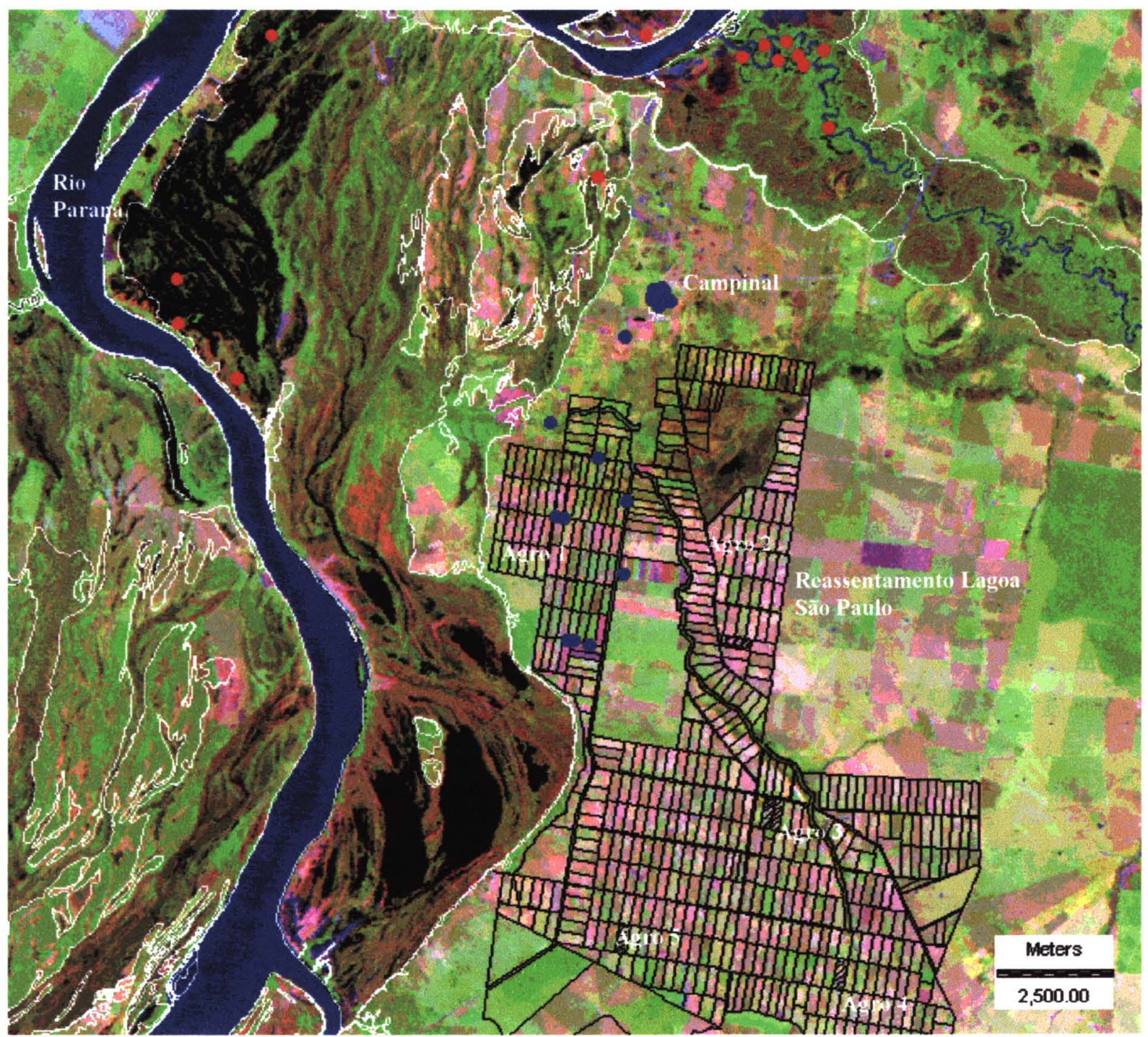

Figura 3 - Composição de Imagens LANDSAT TM345 de 09/03/97.

Área de Estudo: Município de Presidente Epitácio: Campinal e Reassentamento Lagoa

São Paulo (RLSP).

Pontos Azuis: locais de residência dos participantes da amostra.

Pontos Vermelhos: locais de captura dos bugios (Alouatta caraya).

Área Azul Escura: leito original do Rio Paraná.

Linhas Brancas: limites da inundação.

Fonte: MUCCI, 1999. 


\section{Coleta de Sangue de Macacos Capturados nas Áreas de Inundação da UHE de Porto Primavera}

Os macacos da amostra foram capturados pela equipe técnica da Divisão de Resgate de Fauna da CESP (Companhia Energética de São Paulo), composta por veterinários, biólogos e técnicos em Meio Ambiente, com autorização do Instituto Brasileiro de Meio Ambiente (IBAMA). As áreas envolvidas nesta atividade corresponderam às regiões alagadas das margens do Rio Paraná, adjacentes aos Estados de São Paulo e Mato Grosso do Sul. Os trabalhos de resgate de animais ocorreram em dois períodos: maio de 2000 e entre março e maio de 2001.

Foram resgatados aproximadamente 2000 macacos, além de inúmeros exemplares de mamíferos, aves, répteis e anfibios. A grande maioria dos animais foi realocada em grandes fazendas e áreas de preservação no Estado do Mato Grosso do Sul.

Foram obtidas 239 amostras de sangue de bugios (Alouatta caraya), sendo 102 espécimes capturados nas matas ciliares que existiam ao longo do Rio Paraná e Rio do Peixe, no território paulista, em áreas próximas ao Campinal e ao Reassentamento; e 137 de espécimes capturados na margem oposta do rio, no lado do Mato Grosso do Sul.

As amostras de sangue foram coletadas, na maioria pela veia femural, em tubos "vacutainer" com e sem anticoagulante (EDTA), em macacos previamente anestesiados com Ketamina, de acordo com a recomendação ética do "CANADIAN COUNCIL ON ANIMAL CARE (1980/84)". Os procedimentos foram realizados por veterinários das equipes de resgate.

Concomitantemente, foram confeccionadas lâminas de esfregaço e gota espessa de cada animal. As mesmas ficaram acondicionadas em porta-lâminas, até serem coradas.

As amostras de sangue foram separadas no Laboratório da Divisão de Meio Ambiente da CESP, em Presidente Epitácio, seguindo a metodologia descrita no item 3.2., e conservadas em freezer $-20^{\circ} \mathrm{C}$. O material biológico obtido foi transportado 
em gelo seco até o Laboratório de Epidemiologia da Faculdade de Saúde Pública, em São Paulo. As amostras permaneceram conservadas à $-20^{\circ} \mathrm{C}$ até o seu processamento.

As procedências dos macacos resgatados foram determinadas pelo nome da área de captura (por exemplo: nome da Fazenda) e/ou pelas coordenadas obtidas com receptor GPS. Os principais dados biológicos de cada espécime foram registrados em uma planilha de cadastro (espécie, sexo, faixa etária, local de captura, biometria, etc). Uma cópia da mesma foi enviada juntamente com o material biológico.

\section{Exame Parasitológico Direto - Teste de Gota Espessa e Esfregaço Sangüíneo}

A técnica de coloração e identificação de plasmódios, gota espessa, seguiu a metodologia preconizada pela Organização Mundial de Saúde (OMS), descrita por BRUCE-CHWATT (1985). Uma gota de sangue foi colocada em lâmina de microscopia e após a secagem da mesma, a lâmina foi imersa em solução de Azul de Metileno Fosfatado (para desglobinização e pré-coloração). Em seguida, acrescentouse à lâmina corante de Giemsa, que após sete minutos, foi removido com água destilada. Após sua secagem, esta foi examinada ao microscópio óptico com objetiva de imersão $(100 x)$.

O esfregaço sangüíneo consistiu em uma pequena gota extendida em lâmina de microscopia. Após a secagem, o material foi fixado com álcool metílico e corado por 20 minutos em Giemsa a 5\%, previamente preparado em água tamponada destilada, pH 7,2. Após a coloração, a lâmina foi lavada e examinada ao microscópio óptico com objetiva de imersão (100x) (WHO, 1999). 


\section{Biologia Molecular}

\subsection{Extração de DNA Genômico}

O DNA genômico foi extraído de $300 \mu \mathrm{l}$ de cada amostra de sangue (humano ou de macaco) através do Wizard Genomic DNA Purification Kit (Promega-A-1125), segundo o protocolo preconizado pelo fabricante (Anexo 4).

Após o cumprimento das etapas de extração, as amostras de DNA foram ressuspendidas em $50 \mu \mathrm{l}$ de água bidestilada estéril, e armazenadas à $4^{\circ} \mathrm{C}$ até a realização da técnica de "PCR".

Para evidenciar possíveis contaminações, concomitantemente foram extraídos DNA de amostras de sangue humano não parasitado, que serviram como controles negativos para os ensaio de extração e para a reação de "PCR".

\subsection{Reação de Polimerização em Cadeia - "PCR"}

A fim de se fazer uma triagem inicial (presença ou ausência de parasitas do gênero Plasmodium), nas amostras de sangue humanas e de macacos, foram utilizados os "primers" que amplificam uma sequência gênero-específica da região 18S rRNA de plasmódios (OLIVEIRA et al., 1995a):

ALBI01 - 5' ATC AGC TTT TGA TGT TAG GGT ATT G 3'

AL553 - 5' TCC TAT TAA TCG TAA CTA AGC 3'

As amostras que apresentaram fragmentos amplificados com o marcador gênero específico, foram testadas então com os seguintes "primers": 
- AL60 e AL61: "primers" que amplificam a seqüência completa do gene CS de $P$. vivax (QARI et al., 1993). Os produtos amplificados com este marcador foram hibridizados com sondas específicas para diferenciação das variantes: $P$. vivax "clássico" Tipo 1 (VK210), P. vivax (VK247) e P. vivax like-humano/P. simiovale.

AL60 - 5' GTC GGA ATT CAT GAA GAA CTT CAT TCT C 3'

AL61 - 5' CAG CGG ATC CTT AAT TGA ATA ATG CTA GG 3'

- AL62 e AL63: "primers" que amplificam a seqüência completa do gene CS de $P$. malariae/P. brasilianum (cedido juntamente com protocolo da reação, pelo Dr. Shoukat Qari, da Divisão de Doenças Parasitárias do Centro de Controle de Doenças, CDC, Atlanta, Georgia, USA).

AL62 - 5' GTC GGA ATT CAT GAA GAA GTT ATC TGT CTT A 3'

AL63 - 5' CAG CGC ATC CTT AGT CAA AGA GTA TTA AGA C 3'

-ALF1 e ALF2: "primers" que amplificam a região central do gene CS de $P$. falciparum (RANJTT e SHARMA, 1999)

ALF1 - 5' AGA GAT GGA AAT AAC GAA GAC AAC GAC 3'

ALF2 - 5' GTC ATT TGG CAT CAT TAA GTG ACC TTG TCC 3'

Os "primers" foram sintetizados pela Invitrogen do Brasil.

\subsubsection{Descrição da Técnica}

Foram utilizados $5 \mu \mathrm{l}$ de DNA de cada amostra acrescidos de $1 \mu \mathrm{l}$ de cada primer (100 ng/ $\mu$ ), $5 \mu \mathrm{l}$ de Tampão de Reação da Taq Polimerase (10x), 0,5 $\mu \mathrm{l}$ de dNTP mix (20 mM), 0,5 $\mu$ l de Taq Polimerase $(2,5 \mathrm{U} / \mu \mathrm{l})$ e $37 \mu \mathrm{l}$ de água bidestilada estéril, perfazendo $50 \mu \mathrm{l}$ de volume final.

As amostras preparadas foram incubadas no Termo-Ciclador Genius (Techne). 
Para amplificação de fragmentos correspondentes à região gênero-específica 18S rRNA: Desnaturação inicial de $94^{\circ} \mathrm{C}$ durante 5 minutos, seguida de 35 ciclos de $94^{\circ} \mathrm{C}$ durante 1 minuto (desnaturação), $42^{\circ} \mathrm{C}$ durante 50 segundos (alinhamento) e $72^{\circ} \mathrm{C}$ durante 90 segundos (extensão). Finalizando com $72^{\circ} \mathrm{C}$ durante 10 minutos e $4^{\circ}$ C.

Para amplificação de fragmentos correspondentes à seqüência do gene CS de $P$. malariae/P. brasilianum e $P$. vivax: Desnaturação inicial de $94^{\circ} \mathrm{C}$ durante 5 minutos, seguida de 35 ciclos de $93^{\circ} \mathrm{C}$ durante 45 segundos (desnaturação), $42^{\circ} \mathrm{C}$ durante 45 segundos (alinhamento) e $72^{\circ} \mathrm{C}$ durante 2 minutos (extensão). Finalizando com $72^{\circ} \mathrm{C}$ durante 10 minutos e $4^{\circ} \mathrm{C}$.

Para amplificação de fragmentos correspondentes à seqüência do gene CS de P. falciparum: Desnaturação inicial de $94^{\circ} \mathrm{C}$ durante 5 minutos, seguida de 35 ciclos de $94^{\circ} \mathrm{C}$ durante 1 minuto (desnaturação), $58^{\circ} \mathrm{C}$ durante 1 minuto (alinhamento) e $72^{\circ} \mathrm{C}$ durante 1 minuto (extensão). Finalizando com $72^{\circ} \mathrm{C}$ durante 10 minutos e $4^{\circ} \mathrm{C}$.

Em todas as reações, foram incluídos dois controles negativos distintos: um tubo contendo todos os reagentes do PCR e amostra de DNA humano ou de macaco não parasitado, e um tubo com todos os reagentes menos DNA. Como controles positivos foram incluídos DNA de plasmódio correspondentes a cada par de "primers" utilizado, originalmente de sangue de pacientes (P.vivax e P.falciparum) e de cultura de $P$. falciparum (fornecidos pelo Laboratório de Malária da Superintendência de Controle de Endemias SUCEN/SP). Com isso, foi possível controlar possíveis contaminações e falhas no método. 


\subsubsection{Eletroforese em Gel de Agarose}

A eletroforese foi realizada em gel de agarose 1,4\% em tampão TBE (0,089M Trizma base, 0,089M Ácido Bórico, 0,5mM EDTA). A cada $10 \mu \mathrm{l}$ de cada produto obtido foi adicionado $2 \mu \mathrm{l}$ de tampão de amostra (Ficoll 400 15\%, Azul de Bromofenol 0,25\%, EDTA $5 \mathrm{mM}$ ). A corrida eletroforética foi feita no mesmo tampão TBE, por 1 hora à $80 \mathrm{~V}$ (EPS 200 Power Supply PHARMACIA BIOTECH). Como padrão de Peso Molecular foi utilizado $6 \mu \mathrm{l}$ de DNA do 100 bp Ladder $(1 \mu \mathrm{g} / \mu \mathrm{l})$ (GIBCO). O gel foi corado com Brometo de Etídio $(0,5 \mu \mathrm{g} / \mathrm{ml})$, visualizado em transiluminador de U.V., e documentado no Sistema Labworks (UVP).

\section{Testes Imunológicos}

As amostras de soros humanos e de macacos foram submetidas à reação de ELISA com peptídeos sintéticos que mimetizam a porção repetitiva da Proteína Circumsporozoíta (CS) e à reação de Imunofluorescência Indireta (IFI) com antígenos de formas sangüíneas de plasmódios.

\subsection{Reação de ELISA (Enzyme Linked-Immunosorbent Assay)}

A reação para detecção de anticorpos da classe $\mathrm{IgG}$ em soros humanos e de macacos foi baseada na metodologia de ZAVALA et al. (1986), com pequenas modificações (CURADO 1995; CURADO et al., 1997; DUARTE, 1998).

Os peptídeos sintéticos utilizados no estudo mimetizam a região repetitiva específica da Proteína Circumsporozoíta (CS) de plasmódio. 
As seqüências de aminoácidos dos mesmos são as seguintes:

\section{P. vivax Tipo I (clássico) (GDRADGQPA) 2 (GDRAAGQPA) 2 (GDRADGQPA):} peptídeo com 45 aminoácidos, com 9 aminoácidos repetitivos (ARNOT et al., 1985; McCUTCHAN et al., 1985). (Pve)

P. vivax Tipo II (VK247) (ANGAQNQPG)4: peptídeo com 36 aminoácidos, contendo 9 aminoácidos repetitivos (ROSENBERG et al., 1989). (Pvk)

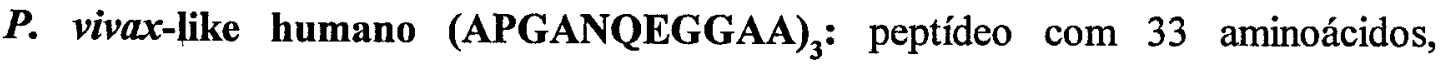
contendo 11 aminoácidos repetitivos (QARI et al., 1993). (Pvl)

P. malariae/P. brasilianum [(NAAG) $\left.]_{4}\right]_{4}$ : peptídeo contendo 4 braços com 16 aminoácidos cada um, com regiões repetitivas de 4 aminoácidos (LAL et al., 1988a,b). (Pm/Pb)

P. falciparum (NANP)s: peptídeo contendo 4 braços com 16 aminoácidos cada um, com regiões repetitivas de 4 aminoácidos (ZAVALA et al., 1986). (Pf)

Os peptídeos foram sintetizados pela Research Genetics (Invitrogen do Brasil).

\subsubsection{Descrição da Reação}

Placas de Poliestireno Maxisorp/NUNC foram sensibilizadas com 100 $\mu \mathrm{l} /$ cavidade dos peptídeos Pm/Pb, Pvc, Pvk, Pvl e Pf à concentração de $10 \mu \mathrm{g} / \mathrm{ml}$. Os peptídeos foram diluídos em PBS $0,15 \mathrm{M} \mathrm{pH} \mathrm{7,2} \mathrm{(solução} \mathrm{salina} \mathrm{tamponada} \mathrm{com}$ fosfatos $0,01 \mathrm{M}$ ).

As placas foram sensibilizadas durante a noite à $4^{\circ} \mathrm{C}$. Após 6 lavagens com PBS 7,2 + Tween 20 0,05\% (PBS-T), foram bloqueadas com PBS-T-Leite 5\% por 2 horas em câmara úmida à temperatura de $37^{\circ} \mathrm{C}$; a seguir a solução de bloqueio foi retirada para a colocação das amostras de soro diluído.

Os soros foram diluídos à 1:10, para teste dos soros de macacos ou 1:50 para os humanos, em PBS-T-Leite 2,5\% e acrescentados no volume de $100 \mu \mathrm{l} /$ cavidade, 
permanecendo por 1 hora em câmara úmida à $37^{\circ} \mathrm{C}$. Após 6 lavagens com PBS-T, seguiu-se a segunda incubação por 1 hora com soro anti-IgG de Macaco (Rhesus) (Sigma A-2054) ou humano (Sigma A-8419) conjugados com peroxidase, diluídos em PBS-T-Leite 2,5\% respectivamente à 1:500 e 1:1000. Novamente foram feitas 6 lavagens seguidas de uma lavagem final somente com PBS pH 7,2. As reações foram reveladas adicionando-se $100 \mu \mathrm{l} /$ cavidade de substrato ABTS.

Após 30 minutos, as reações foram interrompidas com SDS a 10\% (50 $\mu 1 /$ cavidade). As absorbâncias (ABS) foram obtidas por leitura a $414 \mathrm{~nm}$ em leitor de ELISA (Multiskan MCC/340 P).

Em todas as reações acrescentamos soros controles positivos e negativos.

Os soros humanos e de macacos utilizados como controles positivos e negativos para cada peptídeo foram testados anteriormente e, portanto, apresentavam absorbâncias conhecidas (CURADO et al. 1997; DUARTE, 1998).

\subsection{Reação de Imunofluorescência Indireta (IFI)}

Foram utilizados antígenos de formas assexuadas de $P$. vivax, $P$. malariae e $P$. falciparum obtidos respectivamente de pacientes primo - infectados, de macacos infectados experimentalmente e de cultura do parasita.

As lâminas de $P$. vivax e $P$. falciparum foram cedidas pelo Laboratório de Malária do Instituto Evandro Chagas de Belém/Pará. As lâminas de $P$. malariae foram fornecidas pelo Dr. William Collins da Divisão de Doenças Parasitárias do Centro de Controle de Doenças, CDC, Atlanta, Georgia, USA. 


\subsubsection{Descrição da Reação}

A reação foi realizada segundo protocolo de FERREIRA e SANCHEZ (1988), com os antígenos de $P$. malariae, $P$. vivax e $P$. falciparum para pesquisa de anticorpos da classe IgG. Algumas adaptações foram efetuadas para realização dos testes com soros de macacos (DUARTE, 1998).

Os soros humanos e de macacos foram diluídos à razão 2, a partir de 1:40 em PBS pH 7,2 contendo Tween 80 à $1 \%$.

Uma alíquota de $10 \mu \mathrm{l}$ de cada diluição do soro foi depositada em cada orifício da lâmina com o antígeno, seguindo-se incubação em câmara úmida por 30 minutos à $37^{\circ} \mathrm{C}$. Após a primeira incubação, as lâminas foram lavadas 2 vezes por 10 minutos com PBS pH 7,2 e posteriormente secas. Em seguida, cada orifício foi recoberto com Soro anti-IgG de Macaco (Sigma F-3893) ou anti-IgG Humano (Biolab) conjugados com Isotiocianato de Fluoresceína-FITC, diluídos em solução de Azul de Evans. As lâminas foram incubadas durante 30 minutos em câmara úmida à $37^{\circ} \mathrm{C}$. As mesmas foram novamente lavadas 2 vezes por 10 minutos em $\mathrm{PBS}$ pH 7,2 para remoção do excesso de conjugado, secas e montadas com glicerina $\mathrm{pH} 9,5$.

Em todas as reações foram incluídos soros controles positivos e negativos em diluições conhecidas. Os resultados foram expressos em títulos, correspondendo à recíproca da última diluição do soro com reação positiva. 


\section{Análises Estatísticas}

Os dados epidemiológicos foram organizados em um banco de dados no programa Microsoft Excel (2000).

As variáveis consideradas para as análises estatísticas foram as seguintes:

- Amostragem humana: local, sexo, idade, ocupação e tempo de residência.

- Amostragem de macacos: local, sexo, idade.

Os dados estão apresentados em tabelas simples e de dupla entrada. Foram apresentadas as proporções de resultados positivos, calculadas pela razão entre o número de testes positivos e o número de testes realizados, com os respectivos intervalos aproximados de confiança de $95 \%$.

Para a verificação da existência de associação entre as variáveis explanatórias e o resultado da sorologia em ambas populações (humana e de macacos), foi utilizado o teste de associação pelo qui-quadrado de Pearson. A comparação entre os resultados das reações de ELISA e IFI foi realizada utilizando o teste de associação de MacNemar. Para a tomada de decisão utilizou-se o valor descritivo do teste (valor de $\mathrm{p} \leq$ 0,05) (BERQUÓ et al., 1981).

Os dados foram analisados pelo programa estatístico STATA (Stata Corp., 2001).

Os valores obtidos em ELISA (absorbâncias) foram analisados pelo teste não paramétrico de Mann-Whitney para comparação dos diferentes grupos, no programa SIGMASTAT (Jandel Scientific Software, versão 1.0.3.1). 


\section{RESULTADOS}

Os principais resultados das análises, obtidos a partir do inquérito parasitológico e sorológico, da população amostrada humana e de bugios (Alouatta caraya) estão apresentados separadamente a seguir.

\section{Características Demográficas e Ocupacionais da Amostra Humana}

$\mathrm{Na}$ amostra do Campinal, foi observado que 51,5\% (67/130) dos indivíduos pertenceram ao sexo feminino, enquanto $48,5 \%$ (63/130) pertenceram ao sexo masculino. Em relação à idade, houve maior predominância nas primeiras duas categorias, sendo $27,7 \%$ de indivíduos entre $15-24$ anos e $22,3 \%$ de indivíduos entre 25-34 anos (Tabela 4).

Tabela 4 - Distribuição por faixa etária e sexo dos participantes da amostra do subdistrito Campinal, janeiro de 2000.

\begin{tabular}{|c|c|c|c|c|}
\hline \multirow[b]{2}{*}{ IDADE } & \multicolumn{2}{|c|}{ SEXO } & \multirow[b]{2}{*}{ TOTAL } & \multirow[b]{2}{*}{$\%$} \\
\hline & Feminino & Masculino & & \\
\hline $15-24$ & 18 & 18 & 36 & 27,7 \\
\hline $25-34$ & 18 & 11 & 29 & 22,3 \\
\hline $35-44$ & 12 & 11 & 23 & 17,7 \\
\hline $45-54$ & 08 & 06 & 14 & 10,8 \\
\hline $55-64$ & 05 & 04 & 09 & 6,9 \\
\hline $65-74$ & 04 & 08 & 12 & 9,2 \\
\hline$>75$ & 02 & 05 & 07 & 5,4 \\
\hline TOTAL & 67 & 63 & 130 & 100 \\
\hline
\end{tabular}


A amostra do RLSP apresentou na sua distribuição, 43\% (37/86) de indivíduos do sexo feminino e $57 \%$ (49/86) do sexo masculino, sendo observado maior número de indivíduos na primeira faixa de idade (15-24 anos) (Tabela 5).

Tabela 5 - Distribuição por faixa etária e sexo dos participantes da amostra do Reassentamento Lagoa São Paulo (RLSP), janeiro de 2000.

\begin{tabular}{l|c|c|c|c}
\hline \multirow{2}{*}{ IDADE } & \multicolumn{2}{|c|}{ FEXO } & TOTAL & $\%$ \\
\hline $\mathbf{1 5 - 2 4}$ & 07 & 14 & 21 & $\mathbf{2 4 , 4}$ \\
\hline $\mathbf{2 5 - 3 4}$ & 05 & 10 & 15 & $\mathbf{1 7 , 4}$ \\
\hline $\mathbf{3 5 - 4 4}$ & 10 & 06 & 16 & $\mathbf{1 8 , 6}$ \\
\hline $\mathbf{4 5 - 5 4}$ & 03 & 07 & 10 & $\mathbf{1 1 , 6}$ \\
\hline $\mathbf{5 5 - 6 4}$ & 06 & 07 & 13 & $\mathbf{1 5 , 1}$ \\
\hline $\mathbf{6 5 - 7 4}$ & 04 & 01 & 05 & $\mathbf{5 , 9}$ \\
\hline $\mathbf{7 5}$ & 02 & 04 & 06 & $\mathbf{7 , 0}$ \\
\hline TOTAL & $\mathbf{3 7}$ & $\mathbf{4 9}$ & $\mathbf{8 6}$ & $\mathbf{1 0 0 , 0}$ \\
\hline
\end{tabular}

A Tabela 6 apresenta as principais atividades econômicas desenvolvidas pela população do Campinal. A maioria dos participantes da amostra não desenvolviam nenhuma atividade externa, permanecendo em suas residências e realizando tarefas domésticas (aposentados, donas de casa, desempregados). Estas pessoas foram agrupadas na categoria "Lar", que representou 51,5\% (67/130) da amostra. A segunda categoria que se destacou foi "Agricultor", com uma freqüência de $23,1 \%$ (30/130). 
Tabela 6 - Perfil ocupacional dos participantes da amostra do sub-distrito Campinal, janeiro de 2000.

\begin{tabular}{l|c|c}
\hline Ocupação & Freqüência & $\%$ \\
\hline Lar* & 67 & $\mathbf{5 1 , 5}$ \\
\hline Agricultor & 30 & $\mathbf{2 3 , 1}$ \\
\hline Serviços Gerais & 19 & $\mathbf{1 4 , 6}$ \\
\hline Estudante & 13 & $\mathbf{1 0 , 0}$ \\
\hline Pescador & 01 & $\mathbf{0 , 8}$ \\
\hline TOTAL & $\mathbf{1 3 0}$ & $\mathbf{1 0 0 , 0}$ \\
\hline
\end{tabular}

* - donas de casa, aposentados, desempregados

No RLSP, a categoria "Agricultor" apresentou maior freqüência com 53,5\% (46/86), seguido dos participantes inseridos na categoria "Lar", com 30,2\% (26/86) (Tabela 7).

Tabela 7 - Perfil ocupacional dos participantes da amostra do Reassentamento Lagoa São Paulo (RLSP), janeiro de 2000.

\begin{tabular}{l|c|c}
\hline Ocupação & Freqüência & $\%$ \\
\hline Agricultor & 46 & $\mathbf{5 3 , 5}$ \\
\hline Lar* & 26 & $\mathbf{3 0 , 2}$ \\
\hline Estudante & 07 & $\mathbf{8 , 1}$ \\
\hline Pescador & 04 & $\mathbf{4 , 7}$ \\
\hline Serviços Gerais & 03 & $\mathbf{3 , 5}$ \\
\hline TOTAL & $\mathbf{8 6}$ & $\mathbf{1 0 0 , 0}$ \\
\hline
\end{tabular}

* - donas de casa, aposentados 
Finalizando este item, a população amostrada de ambas localidades, Campinal e RLSP não relataram deslocamentos para áreas endêmicas. Algumas famílias são originárias de cidades vizinhas dos lados de São Paulo e Mato Grosso do Sul e de Estados do Nordeste e Sul (Bahia, Pernambuco, Paraná). A população do Município, em geral, é nativa da região.

\subsection{Resultado do Exame Parasitológico de Gota Espessa e Esfregaço da Amostra Humana}

Os resultados das lâminas das 216 pessoas que participaram da amostra foram negativos, tanto em gota espessa quanto em esfregaço, portanto não foi identificado nenhum caso de malária durante o período de coleta de sangue (Janeiro de 2000).

\subsection{Resultados da Reação de Polimerização em Cadeia (PCR) com Amostras de DNA da População Humana}

Devido aos resultados negativos no exame parasitológico (gota espessa/esfregaço), e a ausência de casos notificados nos últimos sete anos, foram testadas em PCR as amostras que apresentaram resultados positivos em ELISA e/ou IFI (54/216) e 30\% das amostras negativas nos testes sorológicos (48/162).

As 102 amostras de DNA (54+48) não amplificaram com os "primers" correspondentes à seqüência gênero-específica de plasmódio $18 \mathrm{~S}$ rRNA, confirmando a ausência de infecções maláricas, já verificada no exame parasitológico de gota espessa e esfregaço, no momento da coleta de sangue (janeiro de 2000). 


\subsection{Resultados da Sorologia da Amostra Humana}

\subsubsection{Determinação dos Limiares de Reatividade (“cut-off”) na Reação de ELISA para Cada Peptídeo}

Os limiares de reatividade para discriminação dos soros positivos ("cut-off") foram obtidos testando-se previamente os cinco peptídeos (Pvc, Pvk, Pvl, Pm/Pb e Pf) com soros humanos sabidamente negativos.

Controles negativos humanos: 50 soros do Banco de Sangue da Fundação Hemocentro do Hospital das Clínicas da Faculdade de Medicina da Universidade de São Paulo (FH-HCFMUSP).

Os limiares de reatividade foram determinados acrescentando-se às médias aritméticas das absorbâncias dos soros negativos humanos, 3 desvios-padrão, obtendo-se assim os valores dos cálculos demonstrados na Tabela 8 (banco de sangue). Estes valores foram considerados como "corte" em uma primeira triagem dos soros.

Para evitar a consideração de soros falso-positivos, após a primeira triagem, um novo "cut-off" foi determinado para cada peptídeo a partir das absorbâncias obtidas de 50 soros da amostra humana (Tabela 8 - área de estudo).

As variações das absorbâncias dos soros negativos testados ("banco de sangue" e "área de estudo") estão demonstradas na mesma tabela.

Portanto, a positividade para cada peptídeo e por conseqüente, a determinação da prevalência na amostra humana foi determinada considerando-se o valor do "cutoff' da área de estudo. 
Tabela 8 - Limiares de reatividade ("cut-off") para as reaçóes de ELISA com os 5 peptídeos. Amostras do Banco de Sangue do HC-FMUSP $(n=50)$, e amostras negativas da área ( $n=50)$. Diluição do soro: 1:50, conjugado anti-IgG Humano: 1:250. Valores expressos em absorbância (414 nm).

\begin{tabular}{|c|c|c|c|c|c|c|}
\hline Soros & \multicolumn{3}{|c|}{ Banco de Sangue } & \multicolumn{3}{|c|}{ Área de Estudo } \\
\hline $\begin{array}{l}\text { Peptídeos } \\
{[10 \mu \mathrm{g} / \mathrm{ml}]}\end{array}$ & Média & D.P. & $\begin{array}{l}\text { "Cut-off" } \\
\text { M+3DP }\end{array}$ & Média & D.P. & $\begin{array}{l}\text { "Cut-off" } \\
\text { M+3DP }\end{array}$ \\
\hline $\mathbf{P m} / \mathbf{P b}^{*}$ & $\begin{array}{c}0.049 \\
(\mathbf{0 . 0 1 8 - 0 . 0 9 1 )}\end{array}$ & 0.019 & 0.106 & $\begin{array}{c}0.043 \\
(\mathbf{0 . 0 0 6 - 0 . 0 9 3 )}\end{array}$ & 0.028 & 0.127 \\
\hline Pve* & $\begin{array}{c}0.039 \\
(0.003-0.100)\end{array}$ & 0.023 & 0.108 & $\begin{array}{c}0.048 \\
(0.007-0.107)\end{array}$ & 0.029 & 0.135 \\
\hline Pvk* & $\begin{array}{c}0.059 \\
(\mathbf{0 . 0 3 5}-\mathbf{0 . 1 0 0 )} \\
\end{array}$ & 0.020 & 0.119 & $\begin{array}{c}0.064 \\
(0.012-0.114) \\
\end{array}$ & 0.029 & 0.151 \\
\hline Pvl* & $\begin{array}{c}0.091 \\
(\mathbf{0 . 0 2 8 - 0 . 1 5 5 )}\end{array}$ & 0.032 & 0.167 & $\begin{array}{c}0.083 \\
(0.034-0.157)\end{array}$ & 0.032 & 0.179 \\
\hline Pf* & $\begin{array}{c}0.041 \\
(\mathbf{0 . 0 1 0 - 0 . 0 8 7 )}\end{array}$ & 0.022 & 0.107 & $\begin{array}{c}0.062 \\
(0.002-0.099)\end{array}$ & 0.020 & 0.122 \\
\hline
\end{tabular}

* $\mathrm{Pm} / \mathrm{Pb}-$ P.malariae/P.brasilianum

Pvc - P.vivax Tipo I

Pvk - P.vivax Tipo II

Pvl - P.vivax-like humano

Pf - P.falciparum

$\mathrm{DP}=$ Desvio-Padrão

( )-Absorbâncias mínimas e máximas dos soros negativos (variação)

\subsubsection{Resultados das Reações de ELISA na Amostra Humana}

Do número total de integrantes da amostra $(n=216), 130$ residentes do Campinal e 86 do RLSP, 38 soros foram reativos na pesquisa de anticorpos da classe IgG contra a região repetitiva da proteína circumsporozoíta (CS) de plasmódio, correspondendo a uma soropositividade de $17,6 \%, \mathrm{CI}(95 \%)(12,8-23,3 \%)$.

Destes soros, $19,2 \%(25 / 130)$ e $15,1 \%(13 / 86)$ foram positivos para um ou mais peptídeos, nas localidades de Campinal e RLSP, respectivamente.

No total da amostra, $82,4 \%$ (178/216) dos soros foram negativos com todos os peptídeos em reação de ELISA, sendo 80,8\% (105/130) do Campinal e 84,9\% (73/86) do RLSP (dados não demonstrados).

Os resultados das frequiências de resultados positivos para cada peptídeo estão demonstrados na Tabela 9. 
No total, a prevalência de reações positivas para o "Complexo vivax" (somatória dos resultados positivos para Pvc, Pvk e Pvl) foi de 17,6\% (38/216), sendo 7,9\% (17/216) para Pvc, 7,4\% (16/216) para Pvl e 2,3\% (5/216) para Pvk. Para Pf e $\mathrm{Pm} / \mathrm{Pb}$, a positividade foi de 5,1\% (11/216) e 3,2 (7/216), respectivamente.

$\mathrm{Na}$ amostra dos residentes do Campinal, a prevalência para o "Complexo vivax" foi de 22,3\% (29/130), sendo 11,5\% (15/130) para Pvc, 7,7\% (10/130) para Pvl e 3,1\% (4/130) para Pvk. Para $\mathrm{Pm} / \mathrm{Pb}$ e Pf, a porcentagem de positivos foi de $3,8 \%(5 / 130)$.

No RLSP, a positividade observada no "Complexo vivax" foi de $10,5 \%$ (9/86), sendo 7,0\% (6/86) para Pvl, 2,3\% (2/86) para Pvc e 1,2\% (1/86) para Pvk. A prevalência para Pf foi de 7,0\% (6/86) e para $\mathrm{Pm} / \mathrm{Pb}$ de $2,3 \%(2 / 86)$.

Tabela 9 - Freqüência de resultados positivos para anticorpos da classe IgG contra a região repetitiva da Proteína Circumsporozoíta (CS) de plasmódio em reação de ELISA com peptídeos sintéticos, nas amostragens dos residentes do sub-distrito Campinal e do Reassentamento Lagoa São Paulo, Presidente Epitácio, janeiro de 2000.

\begin{tabular}{l|c|c|c}
\hline & $\begin{array}{c}\text { Campinal } \\
(\mathbf{n = 1 3 0 )}\end{array}$ & $\begin{array}{c}\text { Reassentamento Lagoa } \\
\text { São Paulo (n=86) }\end{array}$ & $\begin{array}{c}\text { TOTAL } \\
(\mathbf{n = 2 1 6})\end{array}$ \\
\hline Proteína CS - IgG & Pos. (\%) & Pos. (\%) & Pos. (\%) \\
\hline Pvc* $^{*}$ & $15(11,5)$ & $2(2,3)$ & $17(7,9)$ \\
\hline Pvk* $^{*}$ & $4(3,1)$ & $1(1,2)$ & $5(2,3)$ \\
\hline Pvl $^{*}$ & $10(7,7)$ & $6(7,0)$ & $16(7,4)$ \\
\hline Complexo vivax $^{* *}$ & $29(22,3)$ & $9(10,5)$ & $38(17,6)$ \\
\hline Pm/Pb* $^{*}$ & $5(3,8)$ & $2(2,3)$ & $7(3,2)$ \\
\hline Pf $^{*}$ & $5(3,8)$ & $6(7,0)$ & $11(5,1)$ \\
\hline
\end{tabular}

*Pve -P. vivax clássico (Tipo 1)

Pvk - P. vivax variante VK247 (Tipo 2)

Pvl - P. vivax-like humano/P. simiovale

$\mathbf{P m} / \mathbf{P b}$ - P. malariae/P. brasilianum

Pf-P. falciparum

${ }^{* *}$ Complexo vivax - total de positivos para a espécie $P$. vivax 
Apesar de haver uma aparente diferença numérica entre a prevalência de reações positivas para as duas localidades, a mesma não foi estatisticamente significante para os peptídeos utilizados $(\mathrm{p}>0,05)$.

$\mathrm{Na}$ amostra humana, 13 soros reagiram com mais de um peptídeo, representando $34,2 \%$ (13/38) dos soros positivos em ELISA; sendo 10 soros do Campinal $(10 / 25=40,0 \%)$ e 3 do $\operatorname{RLSP}(3 / 13=23,1 \%)$. Na Tabela 10 , estão demonstradas as combinações observadas nos soros que reagiram com mais de um peptídeo.

O número de soros que apresentaram respostas isoladas (positivo apenas com 1 peptídeo) foi de 15 e 10 nas amostras do Campinal e RLSP, respectivamente.

Tabela 10 - Número de soros positivos que reagiram com mais de um peptídeo CS de plasmódio na reação de ELISA, dentre os residentes do sub-distrito Campinal e do Reassentamento Lagoa São Paulo, Presidente Epitácio, janeiro de 2000. Anticorpos da classe IgG.

\begin{tabular}{l|c|c}
\hline Proteína CS - IgG & Campinal (n=25) & RLSP (n=13) \\
\hline Pvc, Pvk, Pvl, Pf* & 1 & 0 \\
\hline Pve, Pvk, Pvl* & 1 & 0 \\
\hline Pvk,Pvl, Pf* & 1 & 1 \\
\hline Pvc, Pvl* & 3 & 0 \\
\hline Pvk, Pvl* & 1 & 0 \\
\hline Pvc, Pf* & 2 & 0 \\
\hline Pve, Pm/Pb* & 1 & 1 \\
\hline Pvl, Pf* & 0 & $\mathbf{3 ( 2 3 , 1 \% )}$ \\
\hline TOTAL & $\mathbf{1 0 ~ ( 4 0 , 0 \% )}$ & \\
\hline *Pvc-P. vivax clássico (Tipo 1) & & \\
Pvk-P. vivax variante VK247 (Tipo 2) & \\
Pvl-P. vivax-like humano/P. simiovale \\
Pm/Pb- P. malariae/P. brasilianum \\
Pf-P. falciparum
\end{tabular}


A distribuição das absorbâncias na amostra humana $(n=216)$, na reação de ELISA com os 5 peptídeos está demonstrada na Figura 4. Foram considerados como limiares de reatividade, os valores obtidos no cálculo dos soros negativos da área de estudo, conforme descrito na Tabela 8 do item1.4.1.

Na figura 5, pode-se observar a distribuição das absorbâncias dos soros dos residentes do Campinal $(\mathrm{n}=130)$ e do RLSP $(\mathrm{n}=86)$.

As absorbâncias dos soros positivos oscilaram entre 0.2 e 0.4 . Somente um soro (Campinal) foi altamente reativo para $\mathrm{Pm} / \mathrm{Pb}$ atingindo uma absorbância de 1.085 .

Nas 2 localidades, Campinal e RLSP, não se observou diferença estatisticamente significante na análise comparativa das médias das absorbâncias obtidas com os peptídeos Pvc, Pvk, $\mathrm{Pm} / \mathrm{Pb}$ e $\mathrm{Pf}(\mathrm{p}>0,05)$. Houve diferença estatisticamente significante com o peptídeo $\operatorname{Pvl}(\mathrm{p}<0,0001)$. 


\section{Humanos $(n=216)$}

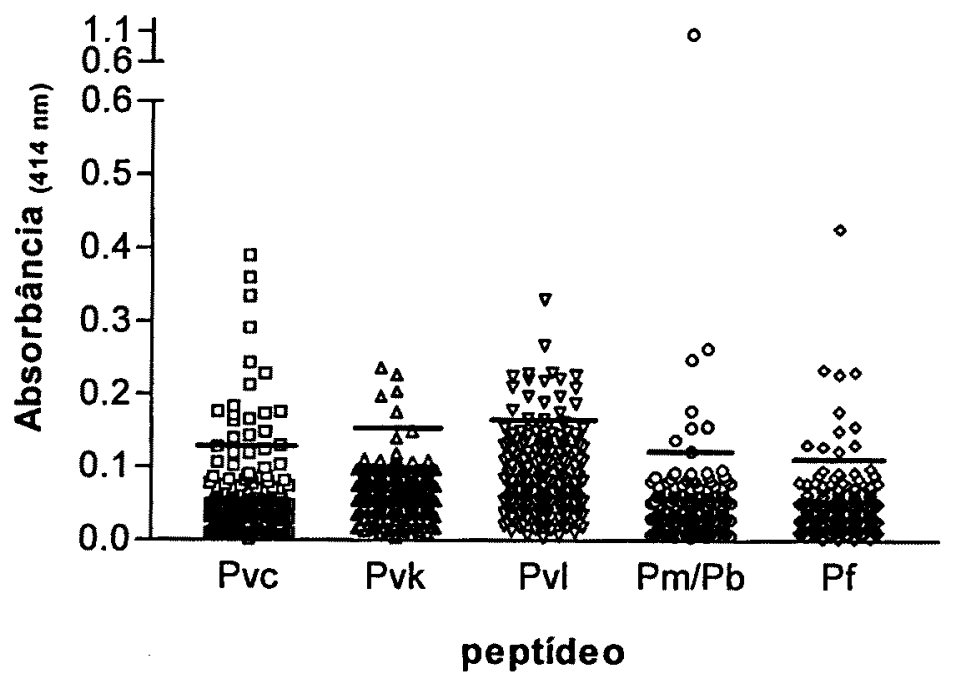

Figura 4 - Distribuição das absorbâncias dos soros humanos para anticorpos da classe IgG contra a região repetitiva da proteína CS de $P$. vivax "clássico" Tipo I (Pvc), P. vivax VK247 Tipo II (Pvk), P. vivax like- humano (Pvl), P. malariaelP. brasilianum $(\mathrm{Pm} / \mathrm{Pb})$ e $P$. falciparum (Pf), na reação de ELISA. Limite superior das barras - limiares de reatividade (média+3 desviospadrão): Pvc=0.135, Pvk=0.151, Pvl=0.179, $\mathrm{Pm} / \mathrm{Pb}=0.127, \mathrm{Pf}=0.122$.
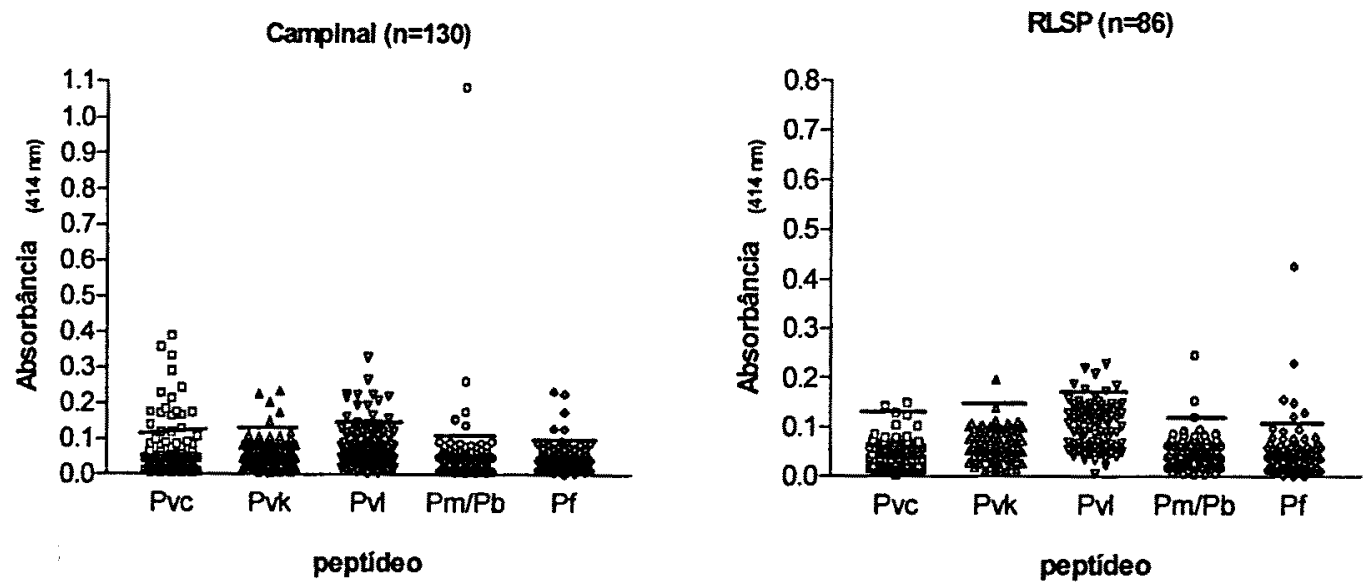

Figura 5 - Distribuição das absorbâncias dos soros humanos do Campinal e do RLSP para anticorpos da classe IgG contra a região repetitiva da proteína CS de $P$. vivax "clássico" Tipo I (Pve), P. vivax VK247 Tipo II (Pvk), P. vivax likehumano (Pvl), P. malariaelP. brasilianum $(\mathrm{Pm} / \mathrm{Pb})$ e $P$. falciparum (Pf), na reação de ELISA. Limite superior das barras - limiares de reatividade (média+3 desvios-padrão): Pvc $=0.135, P v k=0.151, P v l=0.179, P m / P b=0.127$, $\mathbf{P f}=\mathbf{0 . 1 2 2}$. 


\subsubsection{Determinação dos Limiares de Reatividade ("cut-off”) na Reação de Imunofluorescência Indireta (IFI) para cada Antígeno}

Os limiares de reatividade para discriminação dos soros positivos ("cut-off") foram obtidos testando-se previamente os três antígenos ( $P$. vivax, $P$. falciparum e $P$. malariae) com soros humanos sabidamente negativos.

Controles negativos humanos: 50 soros do Banco de Sangue da Fundação Hemocentro do Hospital das Clínicas da Faculdade de Medicina da Universidade de São Paulo (FH-HCFMUSP).

O limiar de reatividade determinado, expresso pela recíproca da diluição, foi de 1:40 para os 3 antígenos, uma vez que os todos soros negativos humanos se mantiveram sempre abaixo deste título.

\subsubsection{Resultados das Reações de Imunofluorescência Indireta (IFI) na Amostra Humana}

As freqüências de resultados positivos na amostra humana com os antígenos de $P$. vivax e $P$. falciparum na reação de IFI estão demonstradas na Tabela 11 .

Do número total de integrantes da amostra $(n=216), 45$ soros foram reativos para anticorpos da classe IgG contra formas sangüíneas de $P$. vivax, que correspondeu a uma soropositividade de $20,8 \%$, CI (95\%) $(15,3-27,7 \%)$.

No total, $79,2 \%(171 / 216)$ dos soros foram negativos para o antígeno de $P$. vivax, sendo 78,5\% (102/130) do Campinal e 80,2\% (69/86) do RLSP.

A positividade para o antígeno de $P$. vivax foi de $21,5 \%(28 / 130)$ e $19,8 \%$ (17/86) dentre os moradores do Campinal e RLSP, respectivamente (Tabela 11).

Os títulos dos soros positivos oscilaram entre as diluições de 1:40 a 1:80, sendo que somente 3 foram positivos até 160 (dados não demonstrados).

Todas as 216 amostras foram negativas para anticorpos da classe IgG contra o antígeno de $P$. falciparum. 
Tabela 11 - Frequiência de resultados positivos para anticorpos da classe IgG contra formas sanguíneas de $P$. vivax e $P$. falciparum na reação de Imunofluorescência Indireta (IFI) nas amostras dos residentes do sub-distrito Campinal e do Reassentamento Lagoa São Paulo, Presidente Epitácio, janeiro de 2000.

\begin{tabular}{l|c|c|c}
\hline & $\begin{array}{c}\text { Campinal } \\
(\mathbf{n}=\mathbf{1 3 0})\end{array}$ & $\begin{array}{c}\text { Reassentamento Lagoa } \\
\text { São Paulo (n=86) }\end{array}$ & $\begin{array}{c}\text { TOTAL } \\
(\mathbf{n}=\mathbf{2 1 6})\end{array}$ \\
\hline Antígeno-IgG & Pos. (\%) & Pos. (\%) & Pos. (\%) \\
\hline P. vivax & $28(21,5)$ & $17(19,8)$ & $45(20,8)$ \\
\hline P. falciparum & $0(0)$ & $0(0)$ & $0(0)$ \\
\hline
\end{tabular}

Apesar de haver uma aparente diferença numérica entre a prevalência de reações positivas para as duas localidades, a mesma não foi estatisticamente significante para os antígenos utilizados $(p>0,05)$.

Em função número limitado de lâminas com o antígeno $P$. malariae e pela impossibilidade de obtenção do mesmo em tempo hábil para apresentação nesta dissertação, foram testadas apenas $30 \%$ da amostra total humana ( $n=216$ ), ou seja, 65 amostras, escolhidas aleatoriamente e, adicionalmente, as amostras positivas em ELISA com o peptídeo de $\mathrm{Pm} / \mathrm{Pb}$.

Das sete amostras positivas para anticorpos $\mathrm{CS}$ de $\mathrm{Pm} / \mathrm{Pb}$ ( 5 do Campinal e 2 do RLSP), apenas 1 (36 RLSP) foi positiva para presença de anticorpos da classe IgG contra formas sangüineas de $P$. malariae, até o título de 160 , as demais amostras foram negativas com este antígeno. Estes resultados não foram incluídos nas análises estatísticas.

\subsubsection{Resultados das Reações de ELISA e IFI na Amostra Humana de Acordo com o Sexo}

A diferença em ELISA, na prevalência de anticorpos contra CS para "Complexo vivax" entre mulheres e homens do Campinal, $20,9 \%$ e $23,8 \%$, respectivamente, não foi estatisticamente significativa. A positividade para os peptídeos Pvc, Pvk e Pvl foi semelhante em ambos os grupos. Para Pf foi observada 
positividade maior no sexo masculino (7,9\%-5/130). Os resultados positivos em IFI com o antígeno de $P$. vivax foram semelhantes para ambos os sexos (Tabela 12).

No RLSP, verificou-se uma maior freqüência no sexo feminino maior, tanto para o peptídeo Pvl do "Complexo vivax" quanto para o Pf, sendo, respectivamente $21,6 \%(8 / 37)$ e $13,5 \%(5 / 37)$, em relação ao sexo masculino 2,0\% (1/49) para os mesmos. Observou-se também, maior freqüência no sexo feminino com o antígeno de $P$. vivax (29,7\%-11/37) (Tabela 12).

Apesar das diferenças numéricas, na análise comparativa das freqüências em ELISA e IFI de acordo com o sexo na amostra do Campinal e do RLSP, não foi observada nenhuma diferença estatisticamente significante, $(\mathrm{p}>0,05)$.

Tabela 12 - Freqüência de resultados positivos, segundo o sexo, para anticorpos da classe IgG contra a região repetitiva da Proteína Circumsporozoíta (CS) de plasmódio na reação de ELISA e contra formas sanguíneas de $P$. vivax e $P$. falciparum na reação de IFI. Amostra dos residentes do sub-distrito Campinal e do Reassentamento Lagoa São Paulo, Presidente Epitácio, janeiro de 2000.

\begin{tabular}{|c|c|c|c|c|}
\hline & \multicolumn{2}{|c|}{$\begin{array}{c}\text { Campinal } \\
(n=130)\end{array}$} & \multicolumn{2}{|c|}{$\begin{array}{c}\text { Reassentamento Lagoa São } \\
\text { Paulo }(\mathrm{n}=86)\end{array}$} \\
\hline & $\begin{array}{c}\text { Fem. } \\
(n=67)\end{array}$ & $\begin{array}{l}\text { Masc. } \\
(n=63)\end{array}$ & $\begin{array}{c}\text { Fem. } \\
(n=37)\end{array}$ & $\begin{array}{l}\text { Masc. } \\
(n=49)\end{array}$ \\
\hline & Pos. (\%) & Pos. (\%) & Pos. (\%) & Pos. (\%) \\
\hline \multicolumn{5}{|c|}{ Proteína CS - IgG } \\
\hline Pve* & $8(11,9)$ & $7(11,1)$ & $2(5,4)$ & $0(0,0)$ \\
\hline Pvk* & $2(3,0)$ & $2(3,2)$ & $1(2,7)$ & $0(0,0)$ \\
\hline Pvl* & $4(6,0)$ & $6(9,5)$ & $5(13,5)$ & $1(2,0)$ \\
\hline $\begin{array}{l}\text { Complexo } \\
\text { vivax** }\end{array}$ & $14(20,9)$ & $15(23,8)$ & $8(21,6)$ & $1(2,0)$ \\
\hline $\mathbf{P m} / \mathbf{P b}^{*}$ & $3(4,5)$ & $2(3,2)$ & $0 \quad(0,0)$ & $2(4,1)$ \\
\hline $\mathbf{P f}^{*}$ & $0(0,0)$ & $5(7,9)$ & $5(13,5)$ & $1(2,0)$ \\
\hline \multicolumn{5}{|l|}{ Antígeno - IgG } \\
\hline P. vivax & $14(20,9)$ & $14(22,2)$ & $11(29,7)$ & $6(12,2)$ \\
\hline P. falciparum & $0(0,0)$ & $0(0,0)$ & $0(0,0)$ & $0(0,0)$ \\
\hline $\begin{array}{l}\text { *Pvc }-P . \text { vivax c } \\
\text { Pvk }-P . \text { vivax } \\
\text { Pvl }-P . \text { vivax-li } \\
\text { Pm/Pb - P. mal } \\
\text { Pf }-P . \text { falcipart } \\
\text { **Complexo viv }\end{array}$ & $\begin{array}{l}\text { (Tipo 1) } \\
\text { Q VK247 } \\
\text { lano/P. si } \\
\text { brasilian }\end{array}$ & $\begin{array}{l}\text { o 2) } \\
\text { vale }\end{array}$ & & \\
\hline
\end{tabular}




\subsubsection{Resultados das Reações de ELISA e IFI na Amostra Humana de Acordo com a Faixa Etária}

Observou-se que os participantes da amostra do Campinal, categorizados nas faixas 14-24, 25-34 e 35-44 e 55-64 anos, apresentaram positividade maior para anticorpos contra CS do "Complexo vivax", nas proporções de 22,2\%, 20,7\%, 26,1\% e 33,3\% respectivamente, em relação as demais. As freqüências para os peptídeos Pvc e Pvl nas primeiras três faixas foi maior em relação às demais faixas e ao peptídeo Pvk. A positividade para os peptídeos $\mathrm{Pm} / \mathrm{Pb}$ e $\mathrm{Pf}$ foi baixa em todas as faixas. No que se refere aos resultados positivos em IFI, com o antígeno de $P$. vivax, a positividade verificada na faixa mais jovem (14-24) apresentou-se mais expressiva (30,6\%-11/36), seguida da faixa $65-74(25,0 \%-3 / 12)$ e $75-94(42,9 \%-3 / 7)$ (Tabela 13).

Tabela 13 - Frequiência de resultados positivos, segundo a faixa etária, para anticorpos da classe IgG contra a região repetitiva da Proteína Circumsporozoíta (CS) de plasmódio na reação de ELISA e contra formas sangüíneas de $P$. vivax e $P$. falciparum na reação de IFI. Amostra dos residentes do sub-distrito Campinal, Presidente Epitácio, janeiro de 2000.

\begin{tabular}{|c|c|c|c|c|c|c|c|}
\hline \multicolumn{8}{|c|}{ Campinal (n=130) } \\
\hline & \multicolumn{6}{|c|}{$\begin{array}{c}\text { Proteína CS - IgG } \\
\text { Pos. (\%) }\end{array}$} & $\begin{array}{c}\text { Antígeno - IgG } \\
\text { Pos.(\%) }\end{array}$ \\
\hline Idade & Pve* & Pvk* $^{*}$ & Pvi* & Comp.vivax ${ }^{* *}$ & $\mathbf{P m} / \mathbf{P b}^{*}$ & $\mathbf{P f}^{*}$ & P. vivax*** \\
\hline $\begin{array}{l}14-24 \\
(n=36)\end{array}$ & $5(13,9)$ & $1(2,8)$ & $2(5,6)$ & $8(22,2)$ & $1(2,8)$ & $2(5,6)$ & $11(30,6)$ \\
\hline $\begin{array}{l}25-34 \\
(n=29)\end{array}$ & $4(13,8)$ & $0(0,0)$ & $2(6,9)$ & $6(20,7)$ & $1(3,5)$ & $0(0,0)$ & $4(13,8)$ \\
\hline $\begin{array}{l}35-44 \\
(n=23)\end{array}$ & $3(13,0)$ & $1(4,4)$ & $2(8,7)$ & $6(26,1)$ & $1(4,4)$ & $1(4,4)$ & $3(13,0)$ \\
\hline $\begin{array}{l}45-54 \\
(n=14)\end{array}$ & $0(0,0)$ & $0(0,0)$ & $1(7,1)$ & $1(7,1)$ & $2(14,3)$ & $0(0,0)$ & $3(21,4)$ \\
\hline $\begin{array}{l}55-64 \\
(n=9)\end{array}$ & $1(11,1)$ & $1(11,1)$ & $1(11,1)$ & $3(33,3)$ & $0(0,0)$ & $1(11,1)$ & $1(11,1)$ \\
\hline $\begin{array}{l}65-74 \\
(\mathrm{n}=12)\end{array}$ & $1(8,3)$ & $0(0,0)$ & $0(0,0)$ & $1(8,3)$ & $0(0,0)$ & $0(0,0)$ & $3(25,0)$ \\
\hline $\begin{array}{l}75-94 \\
(n=7)\end{array}$ & $1(14,3)$ & $1(14,3)$ & $2(28,6)$ & $4(57,1)$ & $0(0,0)$ & $1(14,3)$ & $3(42,9)$ \\
\hline
\end{tabular}

${ }^{*}$ Pve $-P$. vivax clássico (Tipo 1)

Pvk - P. vivax variante VK247 (Tipo 2)

Pvl - P. vivax-like humano/P. simiovale

$\mathbf{P m} / \mathbf{P b}-\mathbf{P}$. malariae/P. brasilianum

Pf -P. falciparum, ${ }^{* *}$ Complexo vivax - total de positivos para a espécie $P$. vivax 
$\mathrm{Na}$ amostra do RLSP, a análise das frequiências para anticorpos CS, com os peptídeos do "Complexo vivax", Pf e $\mathrm{Pm} / \mathrm{Pb}$ não demonstrou diferenças significativas nas 5 primeiras categorias. Nas faixas correspondentes a $65-74$ e 75-94 anos, a porcentagem de positivos para o "Complexo vivax" foi maior $(60,0 \% \mathrm{e}$ $50,0 \%$, respectivamente). Em relação ao antígeno de $P$. vivax em IFI, foi observado maior positividade na faixa $75-94(66,7 \%-4 / 6)$, seguida das faixas $65-74(40,0 \%-$ $2 / 5), 45-54(30,0 \%-3 / 10)$ e 35-44 anos (18,8\%-3/16) (Tabela 14).

Tabela 14 - Frequiência de resultados positivos, segundo a faixa etária, para anticorpos da classe IgG contra a região repetitiva da Proteína Circumsporozoíta (CS) de plasmódio na reação de ELISA e contra formas sangüíneas de $P$. vivax e $P$. falciparum na reação de IFI. Amostra dos residentes do Reassentamento Lagoa São Paulo, Presidente Epitácio, janeiro de 2000.

\begin{tabular}{|c|c|c|c|c|c|c|c|}
\hline \multicolumn{8}{|c|}{ Reassentamento Lagoa São Paulo $(\mathrm{n}=86)$} \\
\hline & \multicolumn{6}{|c|}{$\begin{array}{c}\text { Proteína CS - IgG } \\
\text { Pos. (\%) }\end{array}$} & $\begin{array}{c}\text { Antígeno - IgG } \\
\text { Pos.(\%) }\end{array}$ \\
\hline Idade & Pve* & Pvk* & Pvl* & Comp.vivax** & $\mathbf{P m} / \mathbf{P b}^{*}$ & Pf* & P. vivax** \\
\hline $\begin{array}{l}14-24 \\
(n=21)\end{array}$ & $0(0,0)$ & $0(0,0)$ & $0(0,0)$ & $0(0,0)$ & $0(0,0)$ & $1(4,8)$ & $2(9,5)$ \\
\hline $\begin{array}{l}25-34 \\
(n=15)\end{array}$ & $1(6,7)$ & $0(0,0)$ & $1(6,7)$ & $2(13,3)$ & $0(0,0)$ & $0(0,0)$ & $1(6,7)$ \\
\hline $\begin{array}{l}35-44 \\
(n=16)\end{array}$ & $0(0,0)$ & $0(0,0)$ & $0(0,0)$ & $0(0,0)$ & $0(0,0)$ & $1(6,3)$ & $3(18,8)$ \\
\hline $\begin{array}{l}45-54 \\
(\mathrm{n}=10)\end{array}$ & $0(0,0)$ & $0(0,0)$ & $0(0,0)$ & $0(0,0)$ & $1(10,0)$ & $1(10,0)$ & $3(30,0)$ \\
\hline $\begin{array}{l}55-64 \\
(n=13)\end{array}$ & $0(0,0)$ & $0(0,0)$ & $1(7,7)$ & $1(7,7)$ & $0(0,0)$ & $2(15,4)$ & $2(15,4)$ \\
\hline $\begin{array}{l}65-74 \\
(n=5)\end{array}$ & $0(0,0)$ & $1(20,0)$ & $2(40,0)$ & $3(60,0)$ & $0(0,0)$ & $1(20,0)$ & $2(40,0)$ \\
\hline $\begin{array}{l}75-94 \\
(n=6)\end{array}$ & $1(16,7)$ & $0(0,0)$ & $2(33,3)$ & $3(50,0)$ & $1(16,7)$ & $0(0,0)$ & $4(66,7)$ \\
\hline
\end{tabular}

*Pve - P. vivax clássico (Tipo 1)

Pvk - P. vivax variante VK247 (Tipo 2)

Pvl'-P. vivax-like humano/P. simiovale

$\mathbf{P m} / \mathbf{P b}$ - P. malariae/P. brasilianum

Pf $-P$. falciparum

**Complexo vivax - total de positivos para a espécie $P$. vivax 
Apesar das diferenças numéricas, não foi observada nenhuma diferença estatisticamente significante na análise comparativa das freqüências em ELISA de acordo com a idade dos residentes na amostra do Campinal e do RLSP ( $p>0,05)$.

Observou-se diferença estatisticamente significante, nas amostras do Campinal e do RLSP, na análise comparativa das freqüências em IFI de acordo com a idade dos residentes $(\mathrm{p}<0,0001)$.

\subsubsection{Resultados das reações de ELISA e IFI na Amostra Humana de Acordo com a Ocupação}

A positividade para anticorpos contra CS na amostra do Campinal, de acordo com a ocupação, foi maior dentre as pessoas incluídas na categoria "Agricultor", onde a freqüência observada para o "Complexo vivax" foi de 26,7\% (8/30), seguida da categoria "Lar" que apresentou 23,9\% (16/67). A freqüência para os peptídeos Pvc e Pvl foi maior na categoria "Lar" (10,5 e 9,0\%, respectivamente). Em relação aos resultados da IFI com o antígeno de $P$. vivax, as categorias "Lar", "Agricultor" e "Estudante" destacaram-se com as freqüências de $20,9 \% 23,3 \%$ e $38,5 \%$, respectivamente (Tabela 15 ). 
Tabela 15 - Freqüência de resultados positivos, segundo a ocupação, para anticorpos da classe IgG contra a região repetitiva da Proteína Circumsporozoíta (CS) de plasmódio na reação de ELISA e contra formas sanguíneas de $P$. vivax e $P$. falciparum na reação de IFI. Amostra dos residentes do sub-distrito Campinal, Presidente Epitácio, janeiro de 2000.

\begin{tabular}{|c|c|c|c|c|c|c|c|}
\hline \multicolumn{8}{|c|}{ Campinal $(n=130)$} \\
\hline & \multicolumn{6}{|c|}{$\begin{array}{c}\text { Proteína CS - IgG } \\
\text { Pos. (\%) }\end{array}$} & $\begin{array}{c}\text { Antígeno - IgG } \\
\text { Pos.(\%) }\end{array}$ \\
\hline Idade & Prc* & Pvk* & Pvl* & Comp.vivax** $^{* *}$ & $\mathbf{P m} / \mathbf{P b}^{*}$ & $\overline{P f^{*}}$ & P. vivax ** \\
\hline $\begin{array}{l}\mathbf{L a r}^{1} \\
(\mathrm{n}=67)\end{array}$ & $7(10,5)$ & $3(4,5)$ & $6(9,0)$ & $16(23,9)$ & $2(3,0)$ & $1(1,5)$ & $14(20,9)$ \\
\hline $\begin{array}{l}\text { Agricultor } \\
(\mathrm{n}=30)\end{array}$ & $4(13,3)$ & $1(3,33)$ & $3(10,0)$ & $8(26,7)$ & $1(3,33)$ & $3(10,0)$ & $7(23,3)$ \\
\hline $\begin{array}{l}\text { Ser. Geral } \\
(n=19)\end{array}$ & $2(10,5)$ & $0(0,0)$ & $1(5,3)$ & $3(15,8)$ & $1(5,3)$ & $0(0,0)$ & $2(10,5)$ \\
\hline $\begin{array}{l}\text { Estudante } \\
(\mathrm{n}=13)\end{array}$ & $2(15,4)$ & $0(0,0)$ & $0(0,0)$ & $2(15,4)$ & $1(7,7)$ & $1(7,7)$ & $5(38,5)$ \\
\hline $\begin{array}{l}\text { Pescador } \\
(n=1)\end{array}$ & $0(0,0)$ & $0(0,0)$ & $0(0,0)$ & $0(0,0)$ & $0(0,0)$ & $0(0,0)$ & $0(0,0)$ \\
\hline \multicolumn{8}{|c|}{$\begin{array}{l}\text { *Pve - P. vivax clássico (Tipo 1) } \\
\text { Pvk - P. vivax variante VK247 (Tipo 2) } \\
\text { Pvl - P. vivax-like humano/P. simiovale } \\
\text { Pm/Pb - P. malariae/P. brasilianum } \\
\text { Pf - P. falciparum } \\
\text { **Complexo vivax - total de positivos para a espécie } P \text {. vivax } \\
1 \text { - Lar - donas de casa, aposentados, etc. } \\
\text { 2 - Serviço Geral: pintura, aux. de obras, cargos públicos, emp. domésticas, etc, }\end{array}$} \\
\hline
\end{tabular}

No RLSP, a positividade para CS na categoria "Agricultor" se destacou em relação às outras, apresentando no "Complexo vivax" 14,9\%, sendo 8,5\% para Pvl e 4,3\% para Pvc. Na IFI com o antígeno de $P$. vivax, a categoria de "Agricultor" também se destacou apresentando freqüência de 19,2\% (Tabela 16). 
Tabela 16 - Freqüência de resultados positivos, segundo a ocupação, para anticorpos da classe IgG contra a região repetitiva da Proteína Circumsporozoíta (CS) de plasmódio na reação de ELISA e contra formas sangüíneas de $P$. vivax e $P$. falciparum na reação de IFI. Amostra dos residentes do Reassentamento Lagoa São Paulo, Presidente Epitácio, janeiro de 2000.

\begin{tabular}{|c|c|c|c|c|c|c|c|}
\hline \multicolumn{8}{|c|}{ Reassentamento Lagoa São Paulo $(n=86)$} \\
\hline & \multicolumn{6}{|c|}{$\begin{array}{c}\text { Proteína CS - IgG } \\
\text { Pos. (\%) }\end{array}$} & \begin{tabular}{|c} 
Antígeno - IgG \\
Pos.(\%) \\
\end{tabular} \\
\hline Idade & Pve $^{*}$ & Pvk* & Pvl* $^{*}$ & Comp.vivax ${ }^{* *}$ & $\mathbf{P m} / \mathbf{P b}^{\star}$ & $\mathbf{P f}^{*}$ & P. vivax** \\
\hline $\begin{array}{l}\text { Agricultor } \\
(n=47)\end{array}$ & $2(4,3)$ & $1(2,1)$ & $4(8,5)$ & $7(14,9)$ & $2(4,3)$ & $2(4,3)$ & $9(19,2)$ \\
\hline $\begin{array}{l}\mathbf{L a r}^{1} \\
(\mathrm{n}=26)\end{array}$ & $0(0,0)$ & $0(0,0)$ & $2(7,7)$ & $2(7,7)$ & $0(0,0)$ & $4(15,4)$ & $6(7,7)$ \\
\hline $\begin{array}{l}\text { Estudante } \\
(\mathrm{n}=7)\end{array}$ & $0(0,0)$ & $0(0,0)$ & $0(0,0)$ & $0(0,0)$ & $0(0,0)$ & $0(0,0)$ & $0(0,0)$ \\
\hline $\begin{array}{l}\text { Pescador } \\
(n=4)\end{array}$ & $0(0,0)$ & $0(0,0)$ & $0(0,0)$ & $0(0,0)$ & $0(0,0)$ & $0(0,0)$ & $1(25,0)$ \\
\hline $\begin{array}{l}\text { Ser. Geral }{ }^{2} \\
(n=3)\end{array}$ & $0(0,0)$ & $0(0,0)$ & $0(0,0)$ & $0(0,0)$ & $0(0,0)$ & $0(0,0)$ & $1(33,3)$ \\
\hline 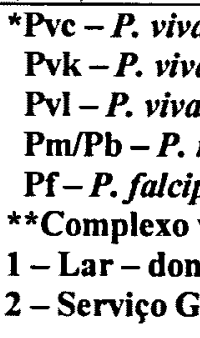 & $\begin{array}{l}\text { clássico (7 } \\
\text { variante } \\
\text { like huma } \\
\text { lariae/P. } \\
\text { um } \\
\text { ax - total } \\
\text { de casa, a } \\
\text { al: pintur }\end{array}$ & $\begin{array}{l}\text { o 1) } \\
247 \text { (Tip } \\
\text { P. simio } \\
\text { silianum } \\
\\
\text { positivo } \\
\text { sentados }\end{array}$ & $\begin{array}{l}\text { ara a } \\
\text { c. } \\
\text { s, car }\end{array}$ & $\begin{array}{l}\text { cie } P . \text { vivax } \\
\text { públicos, em }\end{array}$ & 6 & & \\
\hline
\end{tabular}

Apesar das diferenças numéricas, na amostra do Campinal e do RLSP, não foi observada nenhuma diferença estatisticamente significante na análise comparativa das frequiências em ELISA e IFI de acordo com a ocupação dos residentes ( $p>0,05)$. 


\subsubsection{Resultados das reações de ELISA e IFI na Amostra Humana de Acordo com o Tempo de Residência na Área}

A análise da presença de anticorpos contra proteína CS e contra formas assexuadas, na amostra dos residentes do Campinal, demonstrou relação direta entre o tempo na área e freqüência de soros positivos (Tabela 17).

Considerando a contagem de tempo a partir do ano de realização da coleta de sangue (janeiro de 2000), no Campinal, observou-se ausência de resultados positivos para o "Complexo vivax" (Pvc, Pvk e Pvl) e para Pf nos habitantes, residentes na área há menos de um ano. Entretanto, dois moradores apresentaram resultados positivos para $\mathrm{Pm} / \mathrm{Pb}$ e um indivíduo apresentou anticorpos contra formas sangüíneas de $P$. vivax.

Nas faixas de 2-5 e 6-10 anos observou-se semelhante positividade, para o "Complexo vivax" (33,3\% e 30,0\%, respectivamente), sendo semelhante também a prevalência para Pvc e Pvl e a ausência de positivos para Pvk em ambas faixas. Para $\mathrm{Pm} / \mathrm{Pb}$ e Pf não foram observados resultados positivos. Em IFI para detecção de anticorpos contra formas sangüíneas de $P$. vivax, somente o soros de um indivíduo foi reativo na faixa de 2-5 anos, enquanto que na faixa de 6-10 anos, observou-se positividade de $60 \%$ nesta reação.

Nas últimas duas faixas, 11-20 e $\geq 21$ anos, a positividade para o "Complexo vivax" foi de 15,8 e $27,4 \%$, respectivamente.

$\mathrm{Na}$ faixa de 11-20 anos observou-se um aumento de positivos para Pvc $(13,2 \%)$ e Pvl aparece presente em apenas um indivíduo; a resposta para Pvk continua ausente nesta faixa. A prevalência para $\mathrm{Pm} / \mathrm{Pb}$ e $\mathrm{Pf}$ foi de $5,3 \%$. A positividade para o antígeno $P$. vivax foi de $21,1 \%$.

$\mathrm{Na}$ faixa $\geq 21$ anos, destacou-se a presença de anticorpos contra CS para o peptídeo Pvk, não observada nas faixas anteriores. A positividade dentre os moradores desta faixa foi maior para os peptídeos Pvc $(9,7 \%)$, Pvl $(11,3 \%)$ e Pf $(4,8 \%)$, e maior também, em relação às demais faixas com o antígeno de $P$. vivax $(19,4 \%)$. 
Tabela 17 - Freqüência de resultados positivos, segundo o tempo de residência (anos), para anticorpos da classe IgG contra a região repetitiva da Proteína Circumsporozoíta (CS) de plasmódio na reação e ELISA e contra formas sangüíneas de $P$. vivax e $P$. falciparum na reação de IFI. Amostra dos residentes do sub-distrito Campinal, Presidente Epitácio, janeiro de 2000'.

\begin{tabular}{|c|c|c|c|c|c|c|c|}
\hline \multicolumn{8}{|c|}{ Campinal $(n=130)$} \\
\hline & \multicolumn{6}{|c|}{$\begin{array}{c}\text { Proteína CS - IgG } \\
\text { Pos. (\%) } \\
\end{array}$} & $\begin{array}{c}\text { Antígeno - IgG } \\
\text { Pos.(\%) }\end{array}$ \\
\hline Anos & Pvc* & Pvk* & Pvl* & Comp.vivax** & $\mathbf{P m} / \mathbf{P b}^{*}$ & Pf* & P. vivax** \\
\hline $\begin{array}{l}\leq 1 \\
(n=11)\end{array}$ & $0(0,0)$ & $0(0,0)$ & $0(0,0)$ & $0(0,0)$ & $2(18,2)$ & $0(0,0)$ & $1(9,1)$ \\
\hline $\begin{array}{l}2-5 \\
(n=9)\end{array}$ & $2(22,2)$ & $0(0,0)$ & $1(11,1)$ & $3(33,3)$ & $0(0,0)$ & $0(0,0)$ & $1(11,1)$ \\
\hline $\begin{array}{l}6-10 \\
(n=10)\end{array}$ & $2(20,0)$ & $0(0,0)$ & $1(10,0)$ & $3(30,0)$ & $0(0,0)$ & $0(0,0)$ & $6(60,0)$ \\
\hline $\begin{array}{l}11-20 \\
(\mathrm{n}=38)\end{array}$ & $5(13,2)$ & $0(0,0)$ & $1(2,6)$ & $6(15,8)$ & $2(5,3)$ & $2(5,3)$ & $8(21,1)$ \\
\hline $\begin{array}{l}\geq 21 \\
(n=62)\end{array}$ & $6(9,7)$ & $4(6,5)$ & $7(11,3)$ & $17(27,4)$ & $1(1,6)$ & $3(4,8)$ & $12(19,4)$ \\
\hline $\begin{array}{l}1-\mathrm{a} \text { par } \\
{ }^{*} \mathrm{Pvc}-P \\
\text { Pvk }-P \\
\mathrm{Pvl}-P \\
\mathrm{Pm} / \mathrm{Pb} \\
\mathrm{Pf}-P .\end{array}$ & $\begin{array}{l}\text { a data de } \\
2 x \text { clássic } \\
\text { ax varian } \\
x \text {-like hu } \\
\text { malariaed } \\
\text { parum } \\
\text { viaum }\end{array}$ & $\begin{array}{l}\text { oleta de s } \\
\text { Tipo 1) } \\
\text { VK247 ( } \\
\text { ano/P. sin } \\
\text { brasilian }\end{array}$ & $\begin{array}{l}\text { ngue - Jan } \\
\text { ipo 2) } \\
\text { ovale }\end{array}$ & o de 2000 & & & \\
\hline
\end{tabular}

No RLSP, dentre os residentes com menos de um ano, foi observada ausência de resultados positivos para anticorpos contra CS para o "Complexo vivax" e para $\mathrm{Pf}$, sendo que somente um indivíduo apresentou resposta positiva para $\mathrm{Pm} / \mathrm{Pb}$. Também não foram observadas respostas positivas em IFI para anticorpos contra formas sangüíneas de $P$. vivax (Tabela 18).

$\mathrm{Na}$ faixa de 2-5 anos houve apenas um indivíduo apresentou resultado positivo em IFI para o antígeno de $P$. vivax. A faixa de 6-10 anos apresentou um indivíduo positivo no "Complexo vivax" (Pvl) e um outro em IFI, com o antígeno de P. vivax.

Na faixa 11-20 anos, a prevalência de anticorpos contra CS no "Complexo vivax" foi de $4,2 \%$, sendo todos positivos para o peptídeo Pvl. A prevalência para $\mathrm{Pm} / \mathrm{Pb}$ e Pf foi de $2,1 \%$ e $10,4 \%$, respectivamente. Nesta faixa se destaca o maior número de resultados positivos, em IFI, para o antígeno de $\mathrm{P}$. vivax (22,9\%). 
Na última faixa, $\geq 21$ anos, o resultado que se destacou foi a presença de resposta positiva para o peptídeo Pvk, em um indivíduo que reside há mais de 20 anos no local.

Tabela 18 - Frequiência de resultados positivos, segundo o tempo de residência (anos), para anticorpos da classe IgG contra a região repetitiva da Proteína Circumsporozoíta (CS) de plasmódio na reação de ELISA e contra formas sangüíneas de $P$. vivax e $P$. falciparum na reação de IFI. Amostra dos residentes do Reassentamento Lagoas São Paulo, Presidente Epitácio, janeiro de 2000'.

\begin{tabular}{|c|c|c|c|c|c|c|c|}
\hline \multicolumn{8}{|c|}{ Reassentamento Lagoas São Paulo $(n=86)$} \\
\hline & \multicolumn{6}{|c|}{$\begin{array}{c}\text { Proteína CS - IgG } \\
\text { Pos. (\%) }\end{array}$} & $\begin{array}{c}\text { Antígeno - IgG } \\
\text { Pos.(\%) }\end{array}$ \\
\hline Anos & Pve* & Pvk* & Pvl* & Comp.vivax ${ }^{* * *}$ & $\mathbf{P m} / \mathbf{P b} *$ & $\mathbf{P f}^{*}$ & P. vivax** \\
\hline $\begin{array}{l}\leq 1 \\
(n=5)\end{array}$ & $0(0,0)$ & $0(0,0)$ & $0(0,0)$ & $0(0,0)$ & $1(20,0)$ & $0(0,0)$ & $0(0,0)$ \\
\hline $\begin{array}{l}2-5 \\
(n=4)\end{array}$ & $0(0,0)$ & $0(0,0)$ & $0(0,0)$ & $0(0,0)$ & $0(0,0)$ & $0(0,0)$ & $1(25,0)$ \\
\hline $\begin{array}{l}6-10 \\
(n=2)\end{array}$ & $0(0,0)$ & $0(0,0)$ & $1(50,0)$ & $1(50,0)$ & $0(0,0)$ & $0(0,0)$ & $1(50,0)$ \\
\hline $\begin{array}{l}11-20 \\
(n=48)\end{array}$ & $0(0,0)$ & $0(0,0)$ & $2(4,2)$ & $2(4,2)$ & $1(2,1)$ & $5(10,4)$ & $11(22,9)$ \\
\hline $\begin{array}{l}\geq 21 \\
(n=27)\end{array}$ & $2(7,4)$ & $1(3,7)$ & $3(11,1)$ & $6(22,2)$ & $0(0,0)$ & $1(3,7)$ & $4(14,8)$ \\
\hline $\begin{array}{l}1-\text { a par } \\
* \text { Pvc }-P . \\
\text { Pvk }-P \\
\mathrm{Pvl}-P . \\
\mathrm{Pm} / \mathrm{Pb} \\
\mathrm{Pf}-P .\end{array}$ & $\begin{array}{l}\text { data d } \\
x \text { clássi } \\
x \text { varia } \\
x \text {-like h } \\
\text { nalaria } \\
\text { arum }\end{array}$ & $\begin{array}{l}\text { leta de sa } \\
\text { Tipo 1) } \\
\text { VK247 (T } \\
\text { mo/P. sim } \\
\text { brasiliant }\end{array}$ & $\begin{array}{l}\text { gue - Jan } \\
\text { po 2) } \\
\text { ovale } \\
n\end{array}$ & o de 2000 & & & \\
\hline
\end{tabular}

Houve diferença estatisticamente significante na análise comparativa das frequiências em ELISA e IFI de acordo com o tempo de residência dos residentes na amostra do Campinal e do RLSP ( $\mathrm{p}<0,0001)$.

Não foram relatados deslocamentos para áreas endêmicas de malária dentre os 83 indivíduos positivos nos testes de ELISA e IFI de ambas localidades, indicando que as respostas apresentadas se referem a contatos locais com plasmódios. 


\subsubsection{Comparação entre os Resultados Positivos para Anticorpos Contra Proteína CS (ELISA) e Contra Formas Assexuadas (IFI) de P. vivax}

Na Tabela 19 estão demonstradas 19 amostras positivas que apresentaram anticorpos contra a proteína CS, na reação de ELISA, e contra formas sangüíneas de $P$. vivax, na reação de IFI, sendo 12 do Campinal e 7 do RLSP.

Todas as amostras se referem a moradores que estão na região há mais de 10 anos.

Tabela 19 - Comparação entre os resultados das reações de IFI e ELISA com amostras positivas de indivíduos do Campinal e do Reassentamento Lagoa São Paulo.

\begin{tabular}{|c|c|c|}
\hline & IFI - IgG & ELISA - IgG \\
\hline $\begin{array}{l}\text { Amostra } \\
N^{0} \text {. }\end{array}$ & $\begin{array}{l}\text { Antígeno - } P \text {. vivax } \\
\text { (Título) }\end{array}$ & $\begin{array}{l}\text { Peptídeos - "Complexo vivax*" } \\
\text { (Absorbância -414 nm) }\end{array}$ \\
\hline \multicolumn{3}{|l|}{ Campinal } \\
\hline 72 & 40 & Pvl $(0.197)$ \\
\hline 109 & 40 & Pvk (0.227), Pvl (0.267) \\
\hline 110 & 40 & Pve (0.176) \\
\hline 111 & 40 & Pvc (0.244), Pvk (0.236), Pvl (0.222) \\
\hline 112 & 40 & Pve (0.183) \\
\hline 115 & 40 & Pve (0.166) \\
\hline 116 & 40 & Pvl (0.209) \\
\hline 123 & 40 & Pve (0.172) \\
\hline 126 & 40 & Pve (0.174) \\
\hline 154 & 40 & Pvk (0.176), Pvl (0.229) \\
\hline 165 & 80 & Pve (0.291) \\
\hline 169 & 40 & Pvc (0.390) \\
\hline \multicolumn{3}{|l|}{ RLSP } \\
\hline 05 & 160 & Pvk (0.197), Pvl (0.210) \\
\hline 06 & 160 & Pvc (0.149) \\
\hline 28 & 80 & Pve (0.144), Pvl (0.179) \\
\hline 65 & 80 & $\operatorname{Pvl}(0.230)$ \\
\hline 91 & 40 & Pvl (0.221) \\
\hline 99 & 40 & Pvl (0.187) \\
\hline 104 & 40 & Pvl (0.189) \\
\hline
\end{tabular}




\section{Perfil Populacional da Amostra de Bugios}

$\mathrm{Na}$ distribuição por faixa etária e sexo dos bugios (Alouatta caraya) capturados no lado de São Paulo (SP), 41,2\% (42/102) dos espécimes foram fềmeas e $58,8 \%$ (60/102) machos, sendo que observamos uma maior predominância de espécimes na fase adulta em ambos os sexos 70,6\% (72/102) (Tabela 20).

Tabela 20 - Distribuição por faixa etária e sexo da amostra de bugios (Alouatta caraya) resgatados no lado de São Paulo, nos períodos de maio de 2000 e março à maio de 2001.

\begin{tabular}{l|c|c|c|c}
\hline \multirow{2}{*}{ Faixa etária } & Fêmea & Macho & TOTAL & $\%$ \\
\hline Juvenil & 07 & 09 & 16 & $\mathbf{1 5 , 7}$ \\
\hline Adulto & 34 & 38 & 72 & $\mathbf{7 0 , 6}$ \\
\hline Senil & 01 & 13 & 14 & $\mathbf{1 3 , 7}$ \\
\hline TOTAL & $\mathbf{4 2}$ & $\mathbf{6 0}$ & $\mathbf{1 0 2}$ & $\mathbf{1 0 0 , 0}$ \\
\hline
\end{tabular}

Dos bugios capturados no lado do Mato Grosso do Sul (MS), 38,0\% (52/137) de espécimes foram fềmeas e 62\% (85/137), machos, sendo que a amostra apresentou predominância de adultos em ambos os sexos 69,4 (95/137) (Tabela 21).

Tabela 21 - Distribuição por faixa etária e sexo da amostra de bugios (Alouatta caraya) resgatados no lado do Mato Grosso do Sul, maio de 2000 e março à maio de 2001.

\begin{tabular}{l|c|c|c|c}
\hline \multirow{2}{*}{ Faixa Etária } & Fêmea & Macho & TOTAL & $\%$ \\
\hline Juvenil & 03 & 11 & 14 & 10,2 \\
\hline Adulto & 47 & 48 & 95 & $\mathbf{6 9 , 4}$ \\
\hline Senil & 02 & 26 & 28 & $\mathbf{2 0 , 4}$ \\
\hline TOTAL & $\mathbf{5 2}$ & $\mathbf{8 5}$ & $\mathbf{1 3 7}$ & $\mathbf{1 0 0 , 0}$ \\
\hline
\end{tabular}




\subsection{Resultado do Exame Parasitológico de Gota Espessa e Esfregaço da Amostra de Bugios (Alouatta caraya)}

Das 239 amostras obtidas de bugios (Alouatta caraya), 7 (2,9\%) foram positivas na gota espessa. A parasitemia foi extremamente baixa (2-3 parasitos/lâmina). As formas observadas apresentaram semelhanças morfológicas com $P$. vivax, entretanto, como as lâminas de esfregaço correlatas foram negativas não foi possível afirmar que o agente etiológico seja $P$. vivax ou $P$. simium.

As 7 amostras positivas originaram-se de:

- Bugios capturados no lado de São Paulo: 61 e 178 (2).

- Bugios capturados no lado do Mato Grosso do Sul: 119, 121, 137,145 e 244 (5).

Para confirmação destes resultados, contamos com o auxílio das técnicas especializadas em diagnóstico do Laboratório de Malária da Superintendência de Controle de Endemias (SUCEN).

Foram utilizados dois sistemas para a foto-documentação das imagens dos parasitos encontrados em gota espessa.

As figuras 6,7 e 8 se referem às imagens fotográficas feitas no sistema Axiosphoto-Zeiss, do Laboratório de Imunopatologia do Instituto de Medicina Tropical de São Paulo. Devido à baixa parasitemia associada à qualidade da coloração, que em alguns casos não foi boa o suficiente, as mesmas não forneceram as informações morfológicas necessárias para a correta identificação da espécie. Vale ressaltar que as imagens observadas diretamente ao microscópio permitiram uma melhor visualização que a imagem fotográfica, o que permitiu a detecção das formas de plasmódio. Não foi possível obter fotos melhores que as abaixo demonstradas mesmo utilizando diferentes filtros de tempos de exposição. 


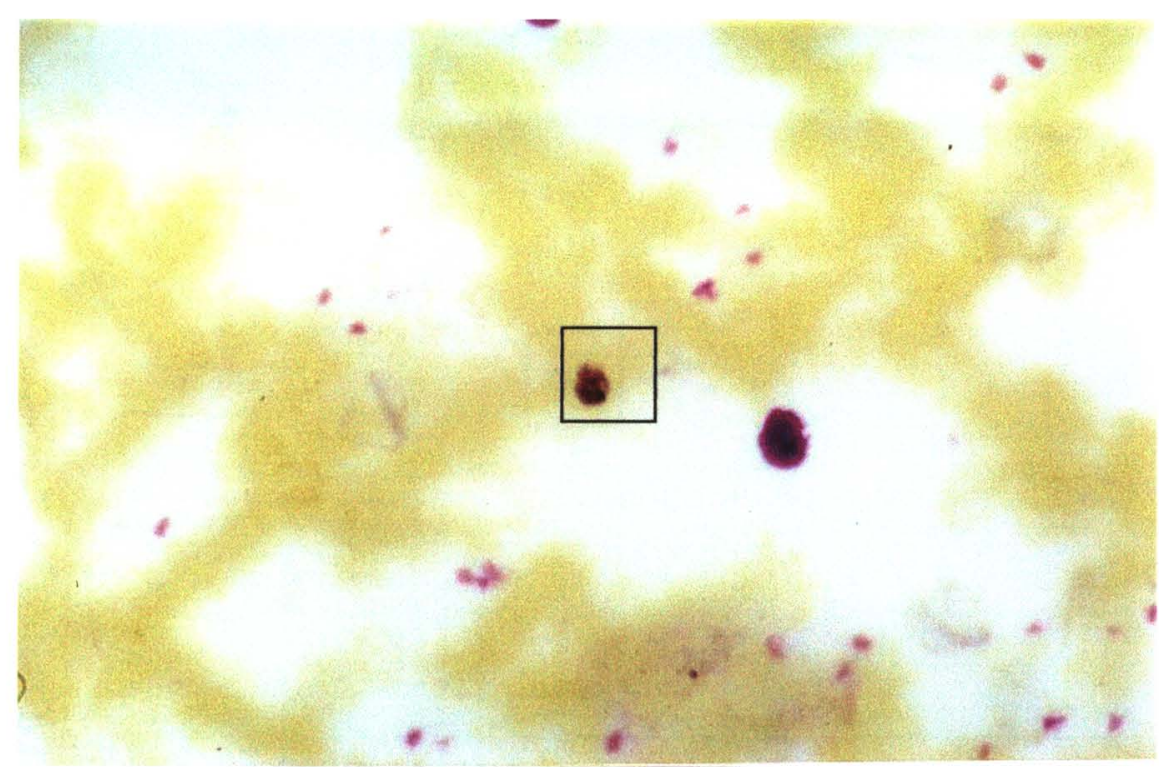

Figura 6 - Gota espessa corada pelo GIEMSA. Gametócito de Plasmodium sp. encontrado em bugio (Alouatta caraya) (Amostra 145), capturado na região do Reservatório da U.H.E de Porto Primavera (1000x). Microscópio Axiosphoto-Zeiss.

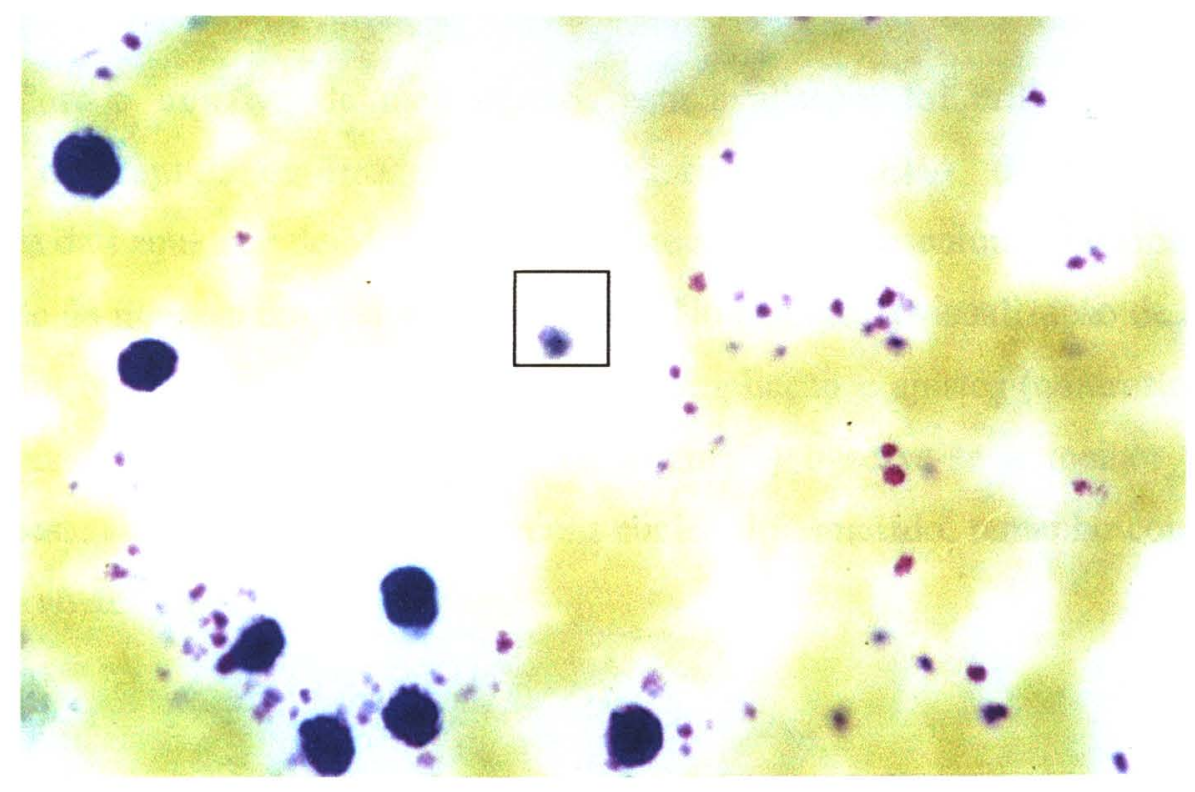

Figura 7 - Gota espessa corada pelo GIEMSA. Gametócito de Plasmodium sp. encontrado em bugio (Alouatta caraya) (Amostra 121), capturado na região do Reservatório da U.H.E de Porto Primavera (1000x). Microscópio Axiosphoto-Zeiss. 


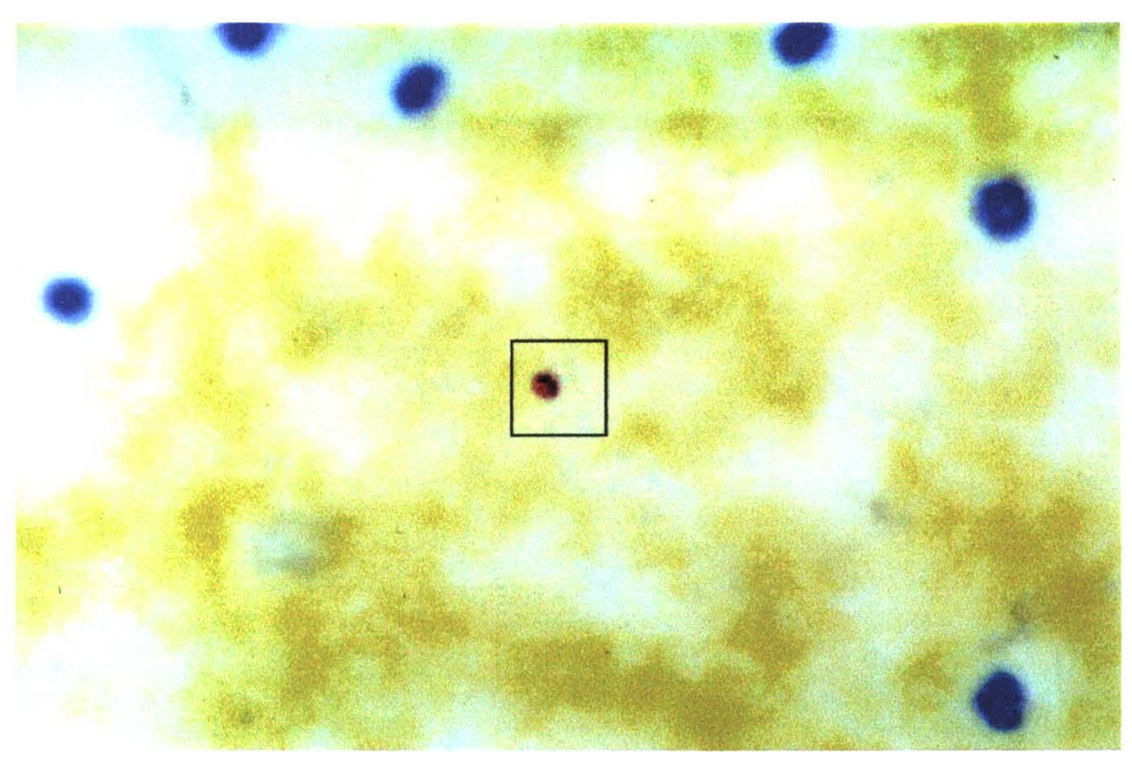

Figura 8 - Gota espessa corada pelo GIEMSA. Trofozoíto de Plasmodium sp. encontrado em bugio (Alouatta caraya) (Amostra 119), capturado na região do Reservatório da U.H.E de Porto Primavera (1000x). Microscópio Axiosphoto-Zeiss.

Com o objetivo de melhorarmos esta avaliação, foi utilizado também o Sistema de Captura de Imagem Computadorizado PIXERA, do Laboratório de Patologia da Faculdade de Medicina/USP. Este sistema apresentou pouca melhora na qualidade da imagem em relação à fotografia. No entanto, a visualização de algumas formas foi otimizada, graças aos recursos de ampliação e ajustes (contraste, brilho, filtros) na imagem computadorizada. Na Figura 9 observa-se a melhor imagem obtida neste sistema, um gametócito, com núcleo diferenciado, tamanho comparável ao de P. vivax. 


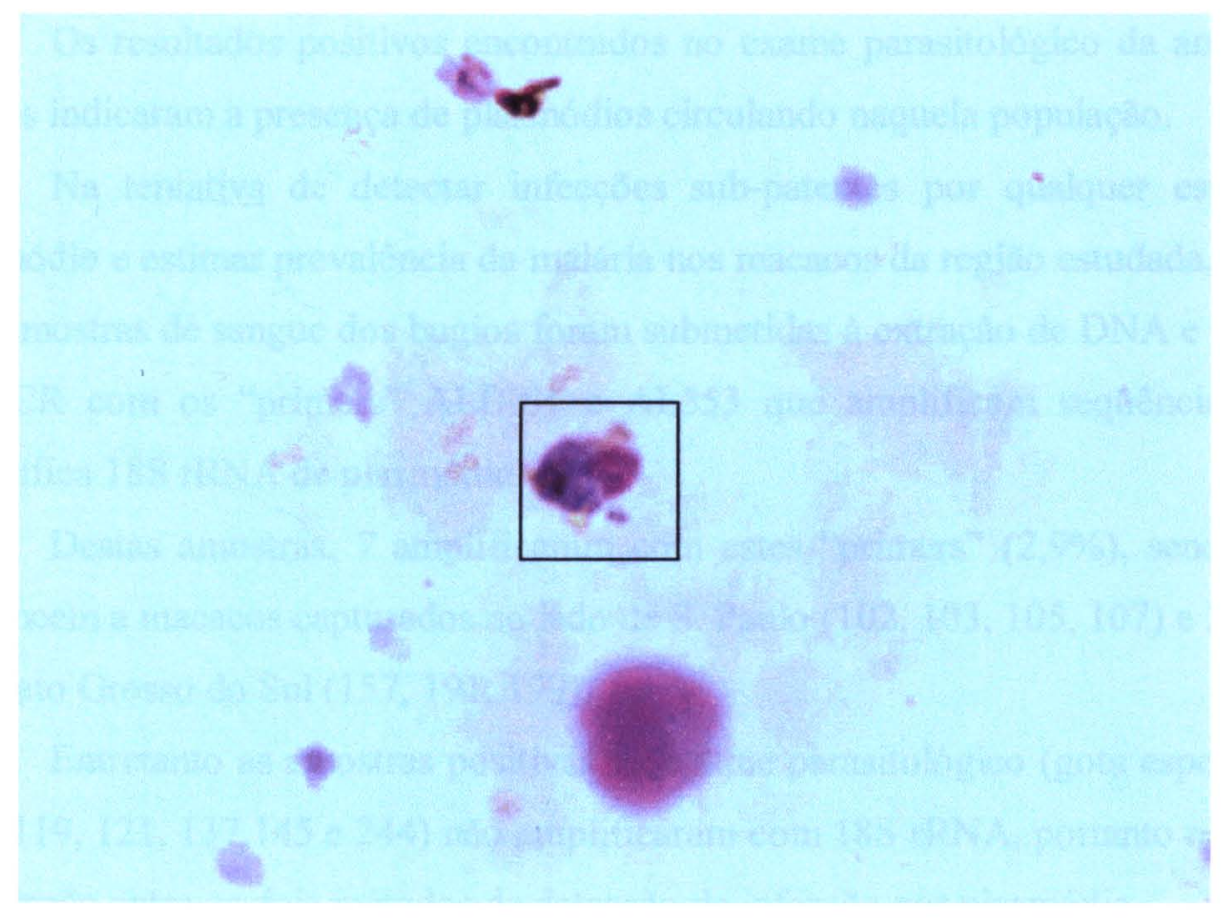

Figura 9 - Gota espessa corada pelo Giemsa. Gametócito de Plasmodium sp. encontrado em bugio (Alouatta caraya) (amostra 137) capturado na região do Reservatório da U.H.E de Porto Primavera. (1000x). Sistema de Captura PIXERA.

As análises morfológicas não foram conclusivas, sendo que alterações nos tamanhos das formas, não correspondentes aos padrões encontrados nas infecções humanas por $P$. vivax, foram observadas e confirmadas pela equipe de diagnóstico da SUCEN (gametócitos maiores com pigmentos malárico, trofozoítos menores). Seria necessária uma quantidade maior de lâminas de cada espécime para tornar possível a identificação baseada no exame morfológico. 


\subsection{Resultados da Reação de Polimerização em Cadeia (PCR) com Amostras de DNA de Bugios (Alouatta caraya)}

Os resultados positivos encontrados no exame parasitológico da amostra de bugios indicaram a presença de plasmódios circulando naquela população.

$\mathrm{Na}$ tentativa de detectar infecções sub-patentes por qualquer espécie de plasmódio e estimar prevalência da malária nos macacos da região estudada, todas as 239 amostras de sangue dos bugios foram submetidas à extração de DNA e à técnica de PCR com os "primers" ALBI01 e AL553 que amplificam seqüência gênero específica $18 \mathrm{~S}$ rRNA de plasmódio.

Destas amostras, 7 amplificaram com estes "primers" (2,9\%), sendo que 4 pertencem a macacos capturados no lado de S. Paulo $(102,103,105,107)$ e 3 no lado do Mato Grosso do Sul $(157,191,199)$.

Entretanto as amostras positivas no exame parasitológico (gota espessa) (61, $178,119,121,137,145$ e 244) não amplificaram com $18 \mathrm{~S}$ rRNA, portanto não houve correlação entre os dois métodos de detecção de infecção por plasmódio.

$\mathrm{Na}$ figura 10, estão demonstrado os produtos amplificados de 5 amostras de DNA amplificadas com "primers" $18 \mathrm{~S}$ rRNA. O controle positivo (10) da reação e a amostra 157 (2) apresentaram fragmentos com o tamanho esperado, com 678 bp. Entretanto as amostras 103 (4), 105 (5) e 107 (6) apresentaram duas bandas, com tamanhos diferentes: $1 \mathrm{~Kb}$ e 800 bp. A amostra 102 (3) apresentou apenas um fragmento de $1 \mathrm{~Kb}$, a amostra 108 (7) apresentou um rastro, porém nenhuma banda específica (resultado negativo). O controle negativo (8) e o "blank" (9) da reação não apresentaram bandas, conforme o esperado. 


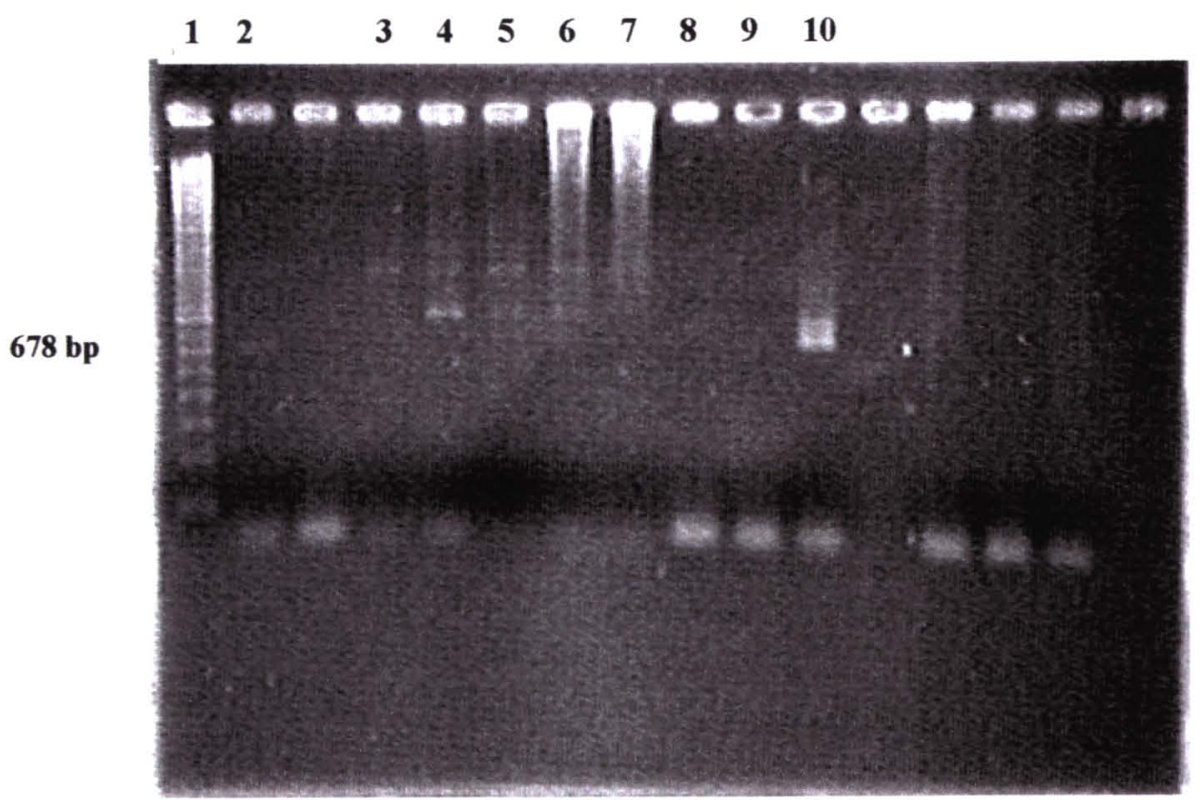

Figura 10 - Eletroforese em gel de agarose 1,4\%. Produtos de PCR amplificados com "primers" ALBI01 e AL553, correspondentes a região 18S de rRNA gênero específica de plasmódio (678 bp). Amostras de DNA de Bugios (Alouatta caraya).1-Peso molecular 100bp DNA ladder (Amersham Pharmacia); 2-Amostra 157 (678 bp); 3-Amostra 102 (+/-1 Kb); 4-Amostra 103 (+/-1 Kb e +/-800 bp); 5- Amostra 105 (+/-1 Kb e +/-800 bp); 6- Amostra 107 (+/-1 Kb e +/-800 bp); 7- Amostra 108 (negativa); 8-Controle negativo (DNA humano); 9-"Blank" (todos os reagentes menos DNA); 10-Controle Positivo: $P$. falciparum (paciente). 
Na figura 11, observam-se 2 amostras de DNA amplificadas com os "primers" ALBI01 e AL553. O controle positivo (4) da reação e a amostra 199 (2) apresentaram fragmentos com o tamanho esperado, com aproximadamente $700 \mathrm{bp}$. Observou-se também que a amostra 191 (3) apresentou fragmento de $800 \mathrm{bp}$.

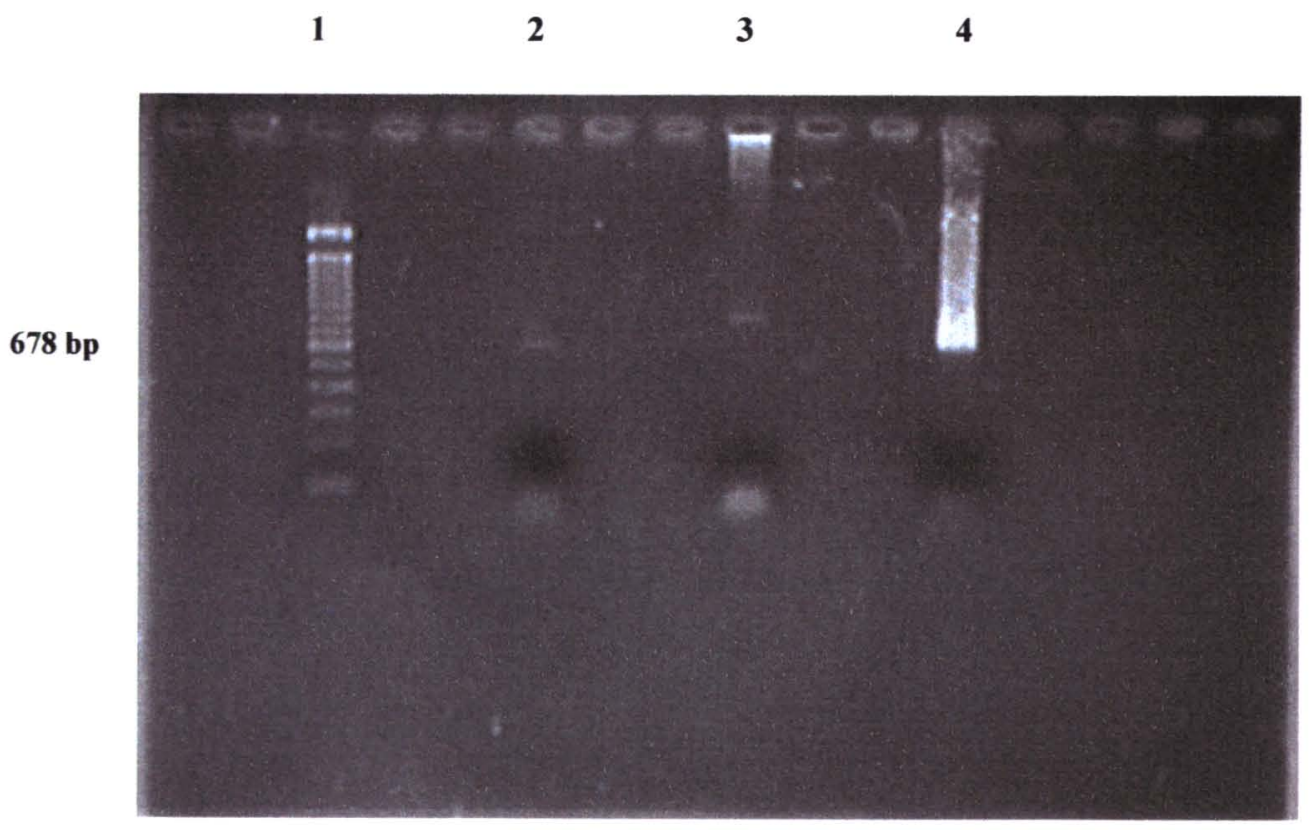

Figura 11 - Eletroforese em gel de agarose 1,4\%. Produtos de PCR amplificados com "primers" ALBI01 e AL553, correspondentes a região 18S de rRNA gênero específica de plasmódio (678 bp). Amostras de DNA de Bugios (Alouatta caraya). 1-Peso molecular 100bp DNA ladder (GIBCO); 2 Amostra 199 (+/-700 bp); 3-Amostra 191 (+/-800 bp); 4-Controle Positivo: P. falciparum (paciente). 
O DNA das 7 amostras que amplificaram com os "primers" $18 \mathrm{~S}$ rRNA, foi submetido à reação com os "primers" que amplificam a sequiência completa do gene CS de $P$. vivax, $P$. malariae e $P$. falciparum. Cinco destas amplificaram fragmentos de tamanhos variados com os "primers" AL60 e AL61 foram positivas para CS de $P$. vivax (Bugios de SP: 103, 105, 107 e do MS: 191 e 199).

As mesmas 7 amostras foram negativas com os "primers" ALF1 e ALF2 de P. falciparum e AL62 e AL63 de P. malariae.

Os produtos amplificados com "primers" AL60 e AL61 também demonstraram variação no tamanho do fragmento correspondente à CS de $P$. vivax, como observado com os "primers" ALBI01 e AL553, 18S rRNA gênero espécifico. O tamanho esperado seria de 1,2 Kb, As amostras 191 (2) e 199 (3) apresentaram fragmentos com 2 bandas cada, 400 e $600 \mathrm{pb}$ (figura 12).

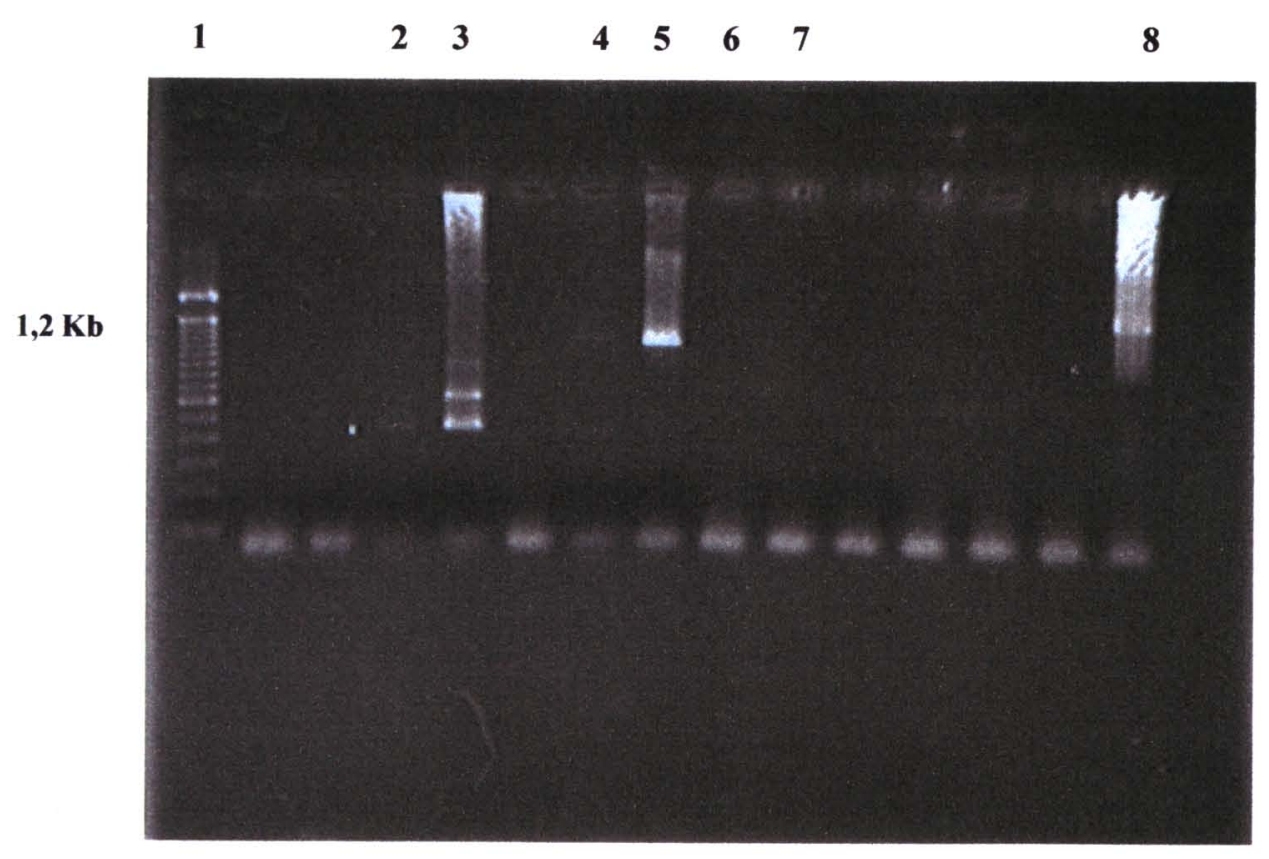

Figura 12 - Eletroforese em gel de agarose 1,4\%. Produtos de PCR amplificados com "primers" AL60 e AL61, correspondentes à porção terminal do gene CS de $P$. vivax (1.2 Kb). Amostras de DNA de Bugios (Alouatta caraya). 1-Peso molecular 100bp DNA ladder (GIBCO); 2-Amostra 191 (+/-400 bp e +/-600 bp), 3-Amostra 199 (+/-400 bp e +/- 600 bp); 4, 5 e 8-Controle positivo ( $P$. vivax obtido de pacientes); 6-Controle negativo (DNA humano) e 7-"blank" (todos os reagentes menos DNA). 
Na figura 13, pode-se visualizar os produtos amplificados referentes ao DNA das amostras 103 (2), 105 (3) e 107 (4) com os "primers" AL60 e AL61 de P. vivax.

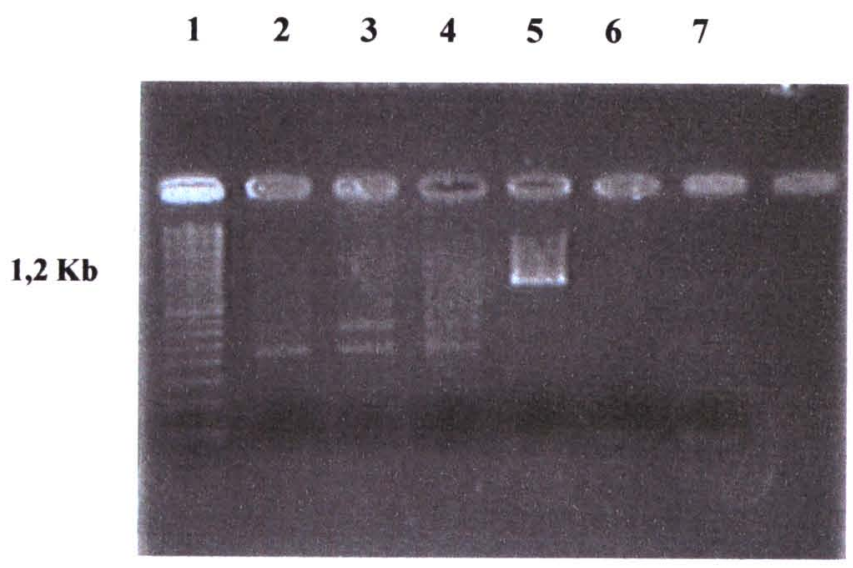

Figura 13 - Eletroforese em gel de agarose 1,4\%. Produtos de PCR amplificados com "primers" Al60 e AL61, correspondentes à porção terminal do gene CS de P. vivax (1.2 Kb). Amostra de Bugios (Alouatta caraya). 1 - Peso molecular 100bp DNA ladder (Amersham Pharmacia); 2Amostra 103 (+/-400 bp e +/- 600 bp);3-Amostra 105 (+/-400 bp e +/- 600 bp); 4-Amostra 107 (+/-400 bp e +/- 600 bp); 5-Controle Positivo (P. vivax obtido de paciente); 6-Controle negativo (DNA humano)e 7-"blank" (todos os reagentes menos DNA). 
Com a finalidade de confirmar os resultados obtidos no exame parasitológico (gota espessa/esfregaço) e das reações de PCR com os "primers" utilizados neste estudo, foi solicitada ao Laboratório de Malária da SUCEN a realização de Nested$\mathrm{PCR}$, com os "primers" utilizados em diagnóstico e em pesquisas de malária da Instituição.

As amostras de DNA correspondentes aos 14 espécimes de bugios que apresentaram resultado positivo quanto a presença de plasmódio, 7 positivos na reação de PCR com os "primers" 18S rRNA e 7 positivos no exame de gota espessa, foram testadas em dois métodos: "Nested PCR" segundo Snounou et al. (1993) e Kimura et al, (1997), respectivamente. Em ambos métodos, é feita uma primeira reação que amplifica regiões conservadas de DNA ribossômico (SSUrRNA) e, uma segunda onde ocorre a amplificação com "primers" espécie específicos.

$\mathrm{Na}$ Tabela 22, estão apresentados os resultados das amostras positivas no exame parasitológico e na reação de PCR, já descritos anteriormente, com também, os resultados das reações realizadas no Laboratório de Malária da SUCEN.

Constatou-se que as amostras positivas no exame de gota espessa não amplificaram com nenhum dos "primers" gênero específicos, seja o utilizado na pesquisa quanto os aplicados no Laboratório de Malária da SUCEN.

Das 7 amostras amplificadas com os "primers" $18 \mathrm{~S}$ gênero específico (ALB101e AL553), todas foram negativas no "Nested-PCR" preconizado por Snounou et al. (1993), e 3 amostras amplificaram com os "primers" espécie específicos na reação "Nested-PCR" pelo método de Kimura et al., 1997). 
Tabela 22 - Comparação entre os resultados das reações de PCR com os "primers" utilizados no estudo e os "primers" utilizados no Laboratório de Malária da SUCEN.

\begin{tabular}{|c|c|c|c|c|c|}
\hline Amostra & $\begin{array}{c}\text { Exame } \\
\text { Parasitol. } \\
\text { (GE/Esfre)\# }\end{array}$ & \begin{tabular}{|c|} 
18S rRNA \\
Gênero específico \\
(ALBI01/AL553) \\
$(678$ bp)
\end{tabular} & $\begin{array}{c}\text { CS P. vivax } \\
(\text { AL60/AL61) } \\
(1200 \mathrm{pb})\end{array}$ & $\begin{array}{c}\text { NestedPCR } \\
\text { (SSUrRNA) } \\
\text { (Snounou } e t \\
\text { al., 1993) } \\
\text { (SUCEN) * }\end{array}$ & $\begin{array}{c}\text { Nested PCR } \\
\text { (SSUrRNA) } \\
\text { (Kimura } \text { et al., 1997) } \\
\text { (SUCEN) * }\end{array}$ \\
\hline \multicolumn{6}{|l|}{ PCR (+) } \\
\hline $102 \mathrm{SP}$ & Neg & 1000 & Neg & Neg & $\mathrm{Neg}$ \\
\hline $103 \mathrm{SP}$ & $\mathrm{Neg}$ & 800 e 1000 & 600 e 400 & Neg & $\mathrm{Neg}$ \\
\hline $105 \mathrm{SP}$ & Neg & 800 e 1000 & 600 e 400 & Neg & Neg \\
\hline $107 \mathrm{SP}$ & Neg & 800 e 1000 & 600 e 400 & Neg & Neg \\
\hline $157 \mathrm{MS}$ & Neg & 700 & Neg & Neg & $P$. vivax** \\
\hline $191 \mathrm{MS}$ & $\mathrm{Neg}$ & 800 e 1000 & 600 e 400 & Neg & P. falciparum** \\
\hline $199 \mathrm{MS}$ & Neg & 800 & 600 e 400 & Neg & $\begin{array}{c}P . \text { vivax e } P \text {. } \\
\text { falciparum }^{* *}\end{array}$ \\
\hline \multicolumn{6}{|c|}{ G. Espessa (+) } \\
\hline 61 SP & Pos & Neg & Neg & Neg & Neg \\
\hline $178 \mathrm{SP}$ & Pos & Neg & $\mathrm{Neg}$ & Neg & Neg \\
\hline $119 \mathrm{MS}$ & Pos & $\mathrm{Neg}$ & Neg & Neg & Neg \\
\hline $121 \mathrm{MS}$ & Pos & Neg & $\mathrm{Neg}$ & $\mathrm{Neg}$ & Neg \\
\hline $137 \mathrm{MS}$ & Pos & Neg & Neg & $\mathrm{Neg}$ & Neg \\
\hline $145 \mathrm{MS}$ & Pos & Neg & $\mathrm{Neg}$ & $\mathrm{Neg}$ & $\mathrm{Neg}$ \\
\hline $244 \mathrm{MS}$ & Pos & $\mathrm{Neg}$ & $\mathrm{Neg}$ & $\mathrm{Neg}$ & Neg \\
\hline
\end{tabular}

A amostra de DNA do bugio157 (MS), quando submetida ao PCR com os "primers" AL553 e ALBI01 (18S rRNA), amplificou fragmento gênero específico de $700 \mathrm{pb}$, de acordo com o esperado, e foi negativa com os "primers" CS (Pv, Pf, e $\mathrm{Pm}$ ), e positiva na reação pelo método de "Kimura" com o "primer" correspondente ao $P$. vivax (resultado não demonstrado).

A amostra 191 (MS), quando submetida ao PCR com "primers" ALBI01 e AL553, apresentou fragmentos de tamanhos maiores que o esperado (800 e $1000 \mathrm{bp}$ ), sendo positiva com os "primers" CS de P. vivax (AL60 e AL61), e também foi positiva na reação pelo método de "Kimura" com o "primer" correspondente ao $P$. falciparum (resultado não demonstrado). 
A amostra 199 (MS), quando submetida ao PCR com "primers" AL553 e ALBI01, apresentou fragmento maior que o esperado (800 bp), sendo positiva com os "primers" CS de $P$. vivax (AL60 e AL61), e também foi positiva na reação pelo método de "Kimura" com os "primers" correspondentes ao $P$. vivax e $P$. falciparum (resultado não demonstrado).

As amostras de DNA dos bugios 102 (SP), 103 (SP), 105 (SP) e 107 (SP), foram positivas somente nas reações de PCR com os "primers" ALBI01 e AL553, gênero específicos e os "primers" CS AL60 e AL61 de $P$. vivax; não apresentando relação com os resultados observados nas reações de "Snounou" e "Kimura".

Em etapa posterior, as amostras de DNA de bugios testadas com os "primers" utilizados neste estudo e que apresentaram resultados negativos (225 amostras, exceto as 14 amostras demonstradas na tabela 22), foram submetidas também à técnica de PCR preconizada por Kimura et al. (1997) (Anexo 5). Os resultados negativos se repetiram, confirmando àqueles descritos anteriormente.

Os produtos amplificados serão futuramente submetidos à reação de seqüênciamento de DNA para comparação com as seqüências de DNA de plasmódio disponiveis no "Genebank". 


\subsection{Resultados da Sorologia da Amostra de Bugios (Alouatta caraya)}

\subsubsection{Determinação dos Limiares de Reatividade ("cut-off") na Reação de ELISA para cada Peptídeo}

Os limiares de reatividade para discriminação dos soros positivos ("cut-off") foram obtidos testando-se previamente os cinco peptídeos (Pvc, Pvk, Pvl, $\mathrm{Pm} / \mathrm{Pb}$ e Pf) com soros de macacos sabidamente negativos.

- Controles negativos de macacos: 40 soros negativos; sendo que dentre estes, 7 soros foram coletados de macacos nascidos em cativeiro do Centro Nacional de Primatas/Pará: 3 amostras de espécimes do gênero Saimiri (macaco-de-cheiro), 2 amostras de Aotus (macaco-da-noite) e 2 amostras de Cebus (macaco-prego); e 43 soros negativos testados por ocasião da minha dissertação de mestrado: 20 soros de espécimes do gênero Alouatta e 13 amostras de Cebus (DUARTE, 1998).

Os limiares de reatividade foram determinados acrescentando-se às médias aritméticas das absorbâncias dos soros negativos de macacos, 3 desvios-padrão, obtendo-se assim os valores dos cálculos demonstrados na tabela 22 (cativeiro). Estes valores foram considerados como "corte" em uma primeira triagem dos soros de macacos da área de estudo.

Para evitar a consideração de soros falsos-positivos, um novo "cut-off" foi determinado para cada peptídeo a partir das absorbâncias obtidas de 50 soros da amostra de bugios, após a primeira triagem (tabela 23 - área de estudo).

As variações das absorbâncias dos soros negativos testados ("cativeiro" e “área de estudo") estão demonstradas na mesma tabela.

Portanto, a positividade para cada peptídeo e por conseqüente, a determinação da prevalência na amostra de bugios foi determinada considerando o valor do "cutoff' da área de estudo. 
Tabela 23 - Limiares de reatividade ("cut-off") para as reações de ELISA com os 5 peptídeos. Amostras de macacos de cativeiro $(\mathrm{N}=40)$ e amostras negativas da área de estudo $(\mathrm{N}=50)$. Diluição do soro: 1:10, conjugado anti-IgG de macaco: 1:3000. Valores expressos em absorbância (414 nm).

\begin{tabular}{l|c|c|c|c|c|c}
\hline \multicolumn{1}{c|}{ Soros } & \multicolumn{3}{|c|}{ Cativeiro } & \multicolumn{3}{c}{ Área de Estudo } \\
\hline $\begin{array}{l}\text { Peptídeos } \\
{[10 \mu \mathrm{g} / \mathrm{ml}]}\end{array}$ & $\begin{array}{c}\text { Média } \\
\text { DO }\end{array}$ & D.P. & $\begin{array}{c}\text { "Cut-off" } \\
\text { M+3DP }\end{array}$ & $\begin{array}{c}\text { Média } \\
\text { DO }\end{array}$ & D.P. & $\begin{array}{c}\text { "Cut-off" } \\
\text { M+3DP }\end{array}$ \\
\hline Pm/Pb* & $\begin{array}{c}0.066 \\
(0.034-0.133)\end{array}$ & 0.042 & 0.192 & $\begin{array}{c}0.076 \\
(\mathbf{0 . 0 0 8 - 0 . 0 8 2})\end{array}$ & 0.049 & $\mathbf{0 . 2 2 3}$ \\
\hline Pvc* $^{0.062}$ & 0.018 & 0.116 & $\begin{array}{c}0.067 \\
(\mathbf{0 . 0 2 3 - 0 . 0 7 5 )}\end{array}$ & 0.027 & $\mathbf{0 . 1 4 8}$ \\
\hline Pvk $^{*}$ & $\begin{array}{c}0.011-0.078) \\
(\mathbf{0 . 0 4 1 - 0 . 1 8 8 )}\end{array}$ & 0.048 & 0.236 & $\begin{array}{c}0.103 \\
(\mathbf{0 . 0 1 8 - 0 . 1 1 0 )}\end{array}$ & 0.047 & $\mathbf{0 . 2 4 4}$ \\
\hline Pvl $^{*}$ & $\begin{array}{c}\mathbf{0 . 1 5 0} \\
(\mathbf{0 . 0 6 7 - 0 . 1 9 4 )}\end{array}$ & 0.039 & 0.267 & $\begin{array}{c}0.116 \\
(\mathbf{0 . 0 1 3 - 0 . 1 2 1})\end{array}$ & 0.045 & $\mathbf{0 . 2 5 1}$ \\
\hline Pf* $^{0.104}$ & 0.049 & 0.251 & $\begin{array}{c}0.090 \\
(\mathbf{0 . 0 0 8 - 0 . 1 0 5 )}\end{array}$ & 0.057 & $\mathbf{0 . 2 6 1}$ \\
\hline
\end{tabular}

${ }^{*} \mathrm{Pm} / \mathrm{Pb}-$ P.malariae/P.brasilianum

Pve - P.vivax Tipo I

Pvk - P.vivax Tipo II

Pvl - P.vivax-like humano

Pf - P.falciparum

$M=$ édia das absorbâncias; $\mathrm{DP}=$ Desvio-Padrão

( )-Absorbâncias mínimas e máximas dos soros negativos (variação)

\subsubsection{Resultados das Reações de ELISA na Amostra de Bugios}

Do número total da amostra de soros coletados de bugios (Alouatta caraya) que compõe a amostra $(n=239), 56$ soros foram reativos para anticorpos da classe IgG contra a proteína circumsporozoíta (CS) de plasmódio, que corresponde à uma soropositividade de $23,4 \%$, CI (95\%) (13,3-15,8\%).

Enquanto que 29,4\% (30/102) da amostra de macacos de São Paulo (SP) foram positivos, a amostra do Mato Grosso do Sul (MS) resultou em 19,0\% (26/137) de soropositividade.

No total da amostra, 76,6\% (183/239) dos soros foram negativos com todos os peptídeos na reação de ELISA, sendo $70,6 \%(72 / 102)$ de macacos do lado de SP e $81,0 \%(111 / 137)$ do lado do MS.

Os resultados das freqüências para cada peptídeo estão demonstrados na tabela 24. 
No total, a prevalência de reações positivas para o "Complexo vivax" foi 13,4\% (32/239), sendo 3,8\% (9/239) para ambos Pvc e Pvl e 5,9\% (14/239) para Pvk. A positividade para $\mathrm{Pm} / \mathrm{Pb}$ e $\mathrm{Pf}$ foi de 9,6\% (23/239) e 8,8\% (21/239), respectivamente.

Nos macacos capturados no lado de SP, a prevalência foi de 19,6\% (20/102) para o "Complexo vivax", sendo 5,9\% (6/102) para ambos Pvc e Pvl e 7,8\% (8/102) para Pvk. Com os peptídeos $\mathrm{Pm} / \mathrm{Pb}$ e $\mathrm{Pf}$ a porcentagem de positivos foi de $12,7 \%$ $(13 / 102)$ e $10,8 \%$ (11/102), respectivamente.

Os macacos capturados no lado do MS, apresentaram positividade de $8,8 \%$ (12/137) para o Complexo vivax, sendo 2,2\% (3/137) para ambos Pvc e Pvl e 4,4\% (6/137) para Pvk. Com ambos os peptídeos de $\mathrm{Pm} / \mathrm{Pb}$ e $\mathrm{Pf}$ a prevalência foi de $7,3 \%$ $(10 / 137)$.

Tabela 24 - Frequiência de resultados positivos para anticorpos da classe IgG contra a região repetitiva da Proteína Circumsporozoíta (CS) de plasmódio na reação de ELISA, na amostra de bugios (Alouatta caraya) capturados nas margens do rio Paraná, correspondentes aos lados de São Paulo e Mato Grosso do Sul, região de Presidente Epitácio, abril de 2000 a maio de 2001.

\begin{tabular}{l|c|c|c}
\hline & $\begin{array}{c}\text { São Paulo } \\
(\mathbf{n}=102)\end{array}$ & $\begin{array}{c}\text { Mato Grosso do Sul } \\
(\mathbf{n}=137)\end{array}$ & $\begin{array}{c}\text { TOTAL } \\
(\mathbf{n}=\mathbf{2 3 9 )}\end{array}$ \\
\hline Proteína CS - IgG & Pos. (\%) & Pos. (\%) & Pos. (\%) \\
\hline Pvc* $^{*}$ & $6(5,9)$ & $3(2,2)$ & $9(3,8)$ \\
\hline Pvk $^{*}$ & $8(7,8)$ & $6(4,4)$ & $14(5,9)$ \\
\hline Pvi $^{*}$ & $6(5,9)$ & $3(2,2)$ & $9(3,8)$ \\
\hline Pmplexo vivax $^{* *}$ & $20(19,6)$ & $12(8,8)$ & $32(13,4)$ \\
\hline Pf $^{*}$ & $13(12,7)$ & $10(7,3)$ & $23(9,6)$ \\
\hline Pvv & $11(10,8)$ & $10(7,3)$ & $21(8,8)$ \\
\hline
\end{tabular}

*Pve -P. vivax clássico (Tipo 1)

Pvk - P. vivax variante VK247 (Tipo 2)

$P v l$ - $P$. vivax-like humano/P. simiovale

$\mathbf{P m} / \mathbf{P b}-\mathbf{P}$. malariae/P. brasilianum

Pf - P. falciparum

**Complexo vivax - total de positivos para a espécie $P$. vivax

Apesar de haver uma aparente diferença numérica entre a prevalência de reações positivas para as duas localidades, a mesma não foi estatisticamente significante entre os peptídeos utilizados $(\mathrm{p}>0,05)$. 
$\mathrm{Na}$ amostra de bugios, 17 soros reagiram com mais de um peptídeo, representando 30,3\% (17/56) dos positivos em ELISA; sendo 11 soros de macacos de SP $(11 / 30=36,7 \%)$, e 6 soros de macacos do MS. $(6 / 26=23,1 \%)$. Na tabela 25 , estão demonstradas as combinações observadas nos soros que reagiram com mais de um peptídeo.

O número de soros que apresentaram respostas isoladas (positivo apenas para 1 peptídeo) foi de 19 na amostra de SP e 20 na amostra do MS.

Tabela 25 - Número de soros positivos que reagiram com mais de um peptídeo CS de plasmódio na reação de ELISA, dentre os macacos capturados no lado de São Paulo e no Mato Grosso do Sul. Anticorpos da classe IgG.

\begin{tabular}{l|c|c}
\hline $\begin{array}{l}\text { Bugios (Alouatta caraya) } \\
\text { Proteína CS - IgG }\end{array}$ & São Paulo (n=30) & M.Grosso do Sul (n=26) \\
\hline Pvc, Pvk, Pm/Pb* & 2 & 0 \\
\hline Pvk,Pm/Pb, Pf* & 1 & 0 \\
\hline Pve, Pf* & 1 & 1 \\
\hline Pvk, Pvl* & 1 & 0 \\
\hline Pvk, Pm/Pb* & 0 & 2 \\
\hline Pvk, Pf* & 1 & 3 \\
\hline Pvl, Pm/Pb* & 3 & 0 \\
\hline Pm, Pf* & 2 & 0 \\
\hline TOTAL & $11(36,7 \%)$ & $6(23,1 \%)$ \\
\hline${ }^{*}$ Pve - P. vivax clássico (Tipo 1) & \\
Pvk-P. vivax variante VK247 (Tipo 2) \\
Pvi - P. vivax-like humano/P. simiovale \\
Pm/Pb - P. malariae/P. brasilianum \\
Pf-P. falciparum
\end{tabular}

A figura 14 demonstra a distribuição das absorbâncias na reação de ELISA, com os 5 peptídeos, nas amostras de soros dos bugios $(n=239)$. Foram considerados como limiares de reatividade os valores obtidos no cálculo dos soros negativos da "área de estudo", como descrito na tabela 23 do item 2.3.1.

Na figura 15, pode-se observar a distribuição das absorbâncias dos soros dos bugios capturados no lado de SP $(n=102)$ e no lado do MS ( $n=137)$. 
Bugios $(n=239)$

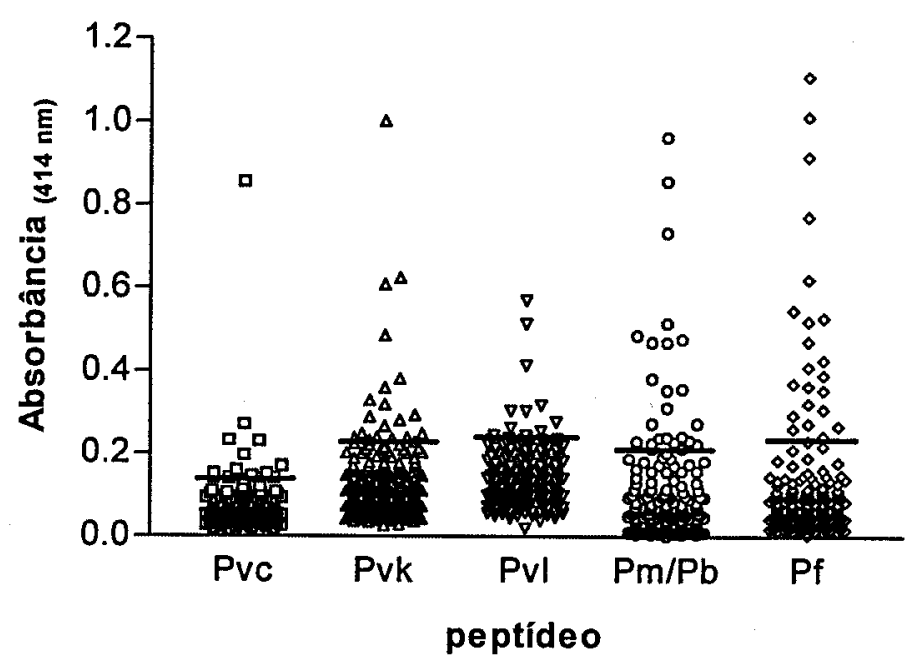

Figura 14 - Distribuição das absorbâncias dos soros de macacos (Alouatta caraya) para anticorpos da classe IgG contra a região repetitiva da proteína CS de $P$. vivax "clássico" Tipo I (Pvc), P. vivax VK247 Tipo II (Pvk), P. vivax like- humano (Pvl), $P$. malariaelP. brasilianum $(\mathrm{Pm} / \mathrm{Pb})$ e $P$. falciparum $(\mathrm{Pf})$ na reação de ELISA. Limite superior das barras - limiares de reatividade (média +3 desviospadrão): Pvc=0.148, Pvk=0.244, Pvl=0.251, $\mathrm{Pm} / \mathrm{Pb}=0.223, \mathrm{Pf}=0.261$.
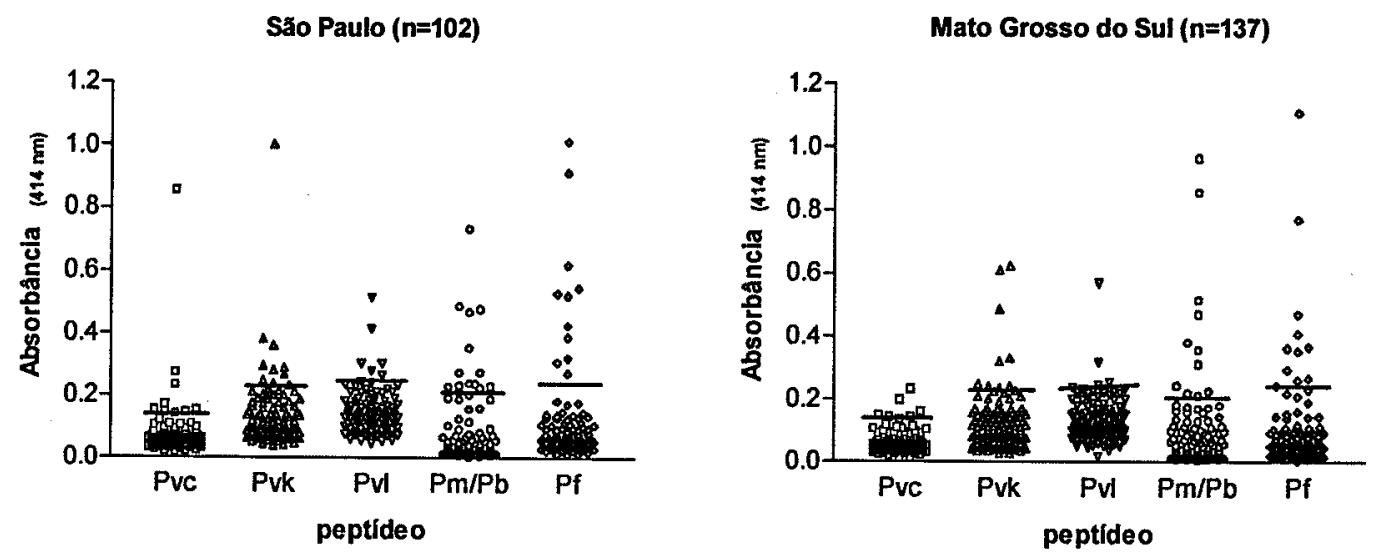

Figura 15 - Distribuição das absorbâncias dos soros de macacos (Alouatta caraya) capturados no lado de São Paulo e do Mato Grosso do Sul para anticorpos da classe IgG contra a região repetitiva da proteína CS de $P$. vivax “clássico" Tipo I (Pve), P. vivax VK247 Tipo II (Pvk), P. vivax like- humano (Pvl), P. malariae/P. brasilianum $(\mathrm{Pm} / \mathrm{Pb})$ e $P$. falciparum $(\mathrm{Pf})$ na reação de ELISA. Limite superior das barras - limiares de reatividade (média +3 desvios-padrão): $P v c=0.148$, $P v k=0.244, P v l=0.251, P m / P b=0.223, P f=0.261$. 
Nota-se ampla dispersão nas absorbâncias dos soros de bugios positivos, que oscilaram entre 0.2 e 1.1. Vários soros apresentaram apresentando absorbâncias altas. Somente o peptídeo Pvl apresentou menor absorbância (0.6).

A análise comparativa das médias das absorbâncias obtidas com os peptídeos Pvc, Pvk, Pvl e Pm/Pb nos macacos capturados no lado de SP e MS não demonstrou diferença estatisticamente significante $(\mathrm{p}>0,05)$.

Houve diferença estatisticamente significante com o peptídeo $\operatorname{Pf}(\mathrm{p}=0.0099)$.

\subsubsection{Determinação dos Limiares de Reatividade (“cut-off”) na reação de Imunofluorescência Indireta (IFI) para cada Antígeno}

Os limiares de reatividade para discriminação dos soros positivos ("cut-off") foram obtidos testando previamente os três antígenos ( $P$. vivax, $P$. falciparum e $P$. malariae) com soros de macacos sabidamente negativos. Foram utilizados os mesmos soros controles negativos descritos no item 4.8.1.

O limiar de reatividade determinado, expresso pela recíproca da diluição, foi de 1:40 para os 3 antígenos, uma vez que os todos soros negativos de macacos se mantiveram sempre abaixo deste título.

\subsubsection{Resultados das Reações de Imunofluorescência Indireta (IFI) na Amostra de Bugios}

Do número total de bugios capturados nas duas localidades $(n=239), 76$ foram soros reativos em IFI, para anticorpos da classe IgG contra formas sangüíneas de plasmódio, que corresponde a uma soropositividade de $31,8 \%$, CI (95\%) $(21,4-$ $35,6 \%)$.

A prevalência de anticorpos para os antígenos de $P$. vivax, $P$. malariae $e P$. falciparum foi de $17,6 \%(42 / 239), 13,4 \%(32 / 239)$ e $5,0 \%(12 / 239)$, respectivamente (tabela 26). 
No total, 163 soros foram negativos para ambos os antígenos, sendo $80 \mathrm{de}$ macacos capturados no lado de SP e 83 no lado do MS.

Na IFI, a positividade para $P$. vivax foi de $15,7 \%(16 / 102)$ e de $19,0 \%$ (26/137) nos bugios de SP e MS, respectivamente. Estes soros apresentaram títulos baixos, sendo que 3 soros apresentaram positividade até o título de 80 e os demais até 40 (dados não demonstrados).

Com o antígeno de $P$. malariae, a prevalência foi de $13,4 \%$ (32/239), sendo $9,8 \%(10 / 102)$ e $16,1 \%(22 / 137)$ nos macacos de SP e MS, respectivamente. Os títulos dos soros positivos variaram entre 40 e 320 (17 amostras reativas até o título de 40, 09 até 80,3 até 160 e 3 até 320 - dados não demonstrados).

Com o antígeno de $P$. falciparum, a positividade foi de 5,9\% (6/102) na amostra de macacos de SP e de 4,4\% (6/137) nos macacos do MS, sendo que os soros positivos não ultrapassaram o título de 1:40 (dados não demonstrados).

Tabela 26 - Frequiência de resultados positivos para anticorpos da classe IgG contra formas sangüíneas de $P$. vivax, $P$. malariae e $P$. falciparum na reação de Imunofluorescência Indireta (IFI) nas amostras dos bugios capturados nas margens do rio Paraná, correspondentes aos lados de São Paulo e Mato Grosso do Sul, região de Presidente Epitácio, abril de 2000 a maio de 2001.

\begin{tabular}{l|c|c|c}
\hline & $\begin{array}{c}\text { São Paulo } \\
(\mathbf{n}=102)\end{array}$ & $\begin{array}{c}\text { Mato Grosso do Sul } \\
(\mathbf{n}=137)\end{array}$ & $\begin{array}{c}\text { TOTAL } \\
(\mathbf{n}=\mathbf{2 3 9})\end{array}$ \\
\hline Antígeno & Pos. (\%) & Pos. $(\%)$ & Pos. $(\%)$ \\
\hline P. vivax & $16(15,7)$ & $26(19,0)$ & $42(17,6)$ \\
\hline P. malariae & $10(9,8)$ & $22(16,1)$ & $32(13,4)$ \\
\hline P. falciparum & $6(5,9)$ & $6(4,4)$ & $12(5,0)$ \\
\hline
\end{tabular}

Apesar de haver uma aparente diferença numérica entre os antígenos utilizados, a prevalência de reações positivas para as duas localidades não foi estatisticamente significante $(p>0,05)$. 


\subsubsection{Resultados das Reações de ELISA e IFI na Amostra de Bugios de Acordo com o Sexo}

A distribuição da soropositividade em ELISA para os peptídeos CS na amostra de macacos de SP, de acordo com o sexo, demonstrou que houve diferença siginificante apenas para o peptídeo Pf, sendo $16,7 \%(10 / 102)$ para fềmeas e $2,4 \%$ (1/102) para machos, enquanto que para os peptídeos do "Complexo vivax" e $\mathrm{Pm} / \mathrm{Pb}$, a soropositividade foi semelhante. Em IFI, a positividade para o antígeno de $P$. malariae foi maior nos machos (19\%-8/42), com antígenos de $P$ vivax e $P$. falciparum não se observou distinção entre as freqüências (Tabela 27).

$\mathrm{Na}$ amostra de bugios do MS, a positividade para anticorpos contra o "Complexo vivax" se concentrou nas fềmeas (11,8\%-10/137) em relação aos machos (3,8\%-2/137). O mesmo ocorreu com os peptídeos $\mathrm{Pm} / \mathrm{Pb}(10,6 \%-9 / 137)$ e $\mathrm{Pf}(9,4 \%$ 8/137) em relação aos machos (1,9\%-1/137 e 3,8\%-2/137), respectivamente.

Em IFI com o antígeno de P.vivax, novamente as fềmeas capturadas no lado de MS se destacaram apresentando $21,2 \%$ (18/137) de positividade em relação aos machos (15,4\%-8/137). Com o antígeno de $P$. malariae, ao contrário, os machos apresentaram maior prevalência $(34,6 \%-18 / 52)$ em relação às fềmeas $(4,7 \%-4 / 85)$. A prevalência para $P$. falciparum foi de $4,7 \%$ (4/137) para as fềmeas e 3,8\% (2/137) para os machos (Tabela 27). 
Tabela 27 - Freqüência de resultados positivos, segundo o sexo, para anticorpos da classe IgG contra a região repetitiva da Proteína Circumsporozoíta (CS) de plasmódio na reação de ELISA e contra formas sangüíneas de $P$. vivax, $P$. malariae e $P$. falciparum na reação de IFI. Amostras de bugios capturados nas margens do rio Paraná, correspondentes aos lados de São Paulo e Mato Grosso do Sul, região de Presidente Epitácio, abril de 2000 a maio de 2001.

\begin{tabular}{|c|c|c|c|c|}
\hline & \multicolumn{2}{|c|}{$\begin{array}{c}\text { São Paulo } \\
(\mathrm{n}=102)\end{array}$} & \multicolumn{2}{|c|}{$\begin{array}{c}\text { Mato Grosso do Sul } \\
(\mathrm{n}=137)\end{array}$} \\
\hline & $\begin{array}{l}\text { Fêmea } \\
(n=60)\end{array}$ & $\begin{array}{l}\text { Macho } \\
(\mathrm{n}=42)\end{array}$ & $\begin{array}{l}\text { Fêmea } \\
(\mathrm{n}=85)\end{array}$ & $\begin{array}{l}\text { Macho } \\
(\mathrm{n}=52)\end{array}$ \\
\hline & Pos. (\%) & Pos. (\%) & Pos. (\%) & Pos. (\%) \\
\hline \multicolumn{5}{|c|}{ Proteína CS-IgG } \\
\hline Pvc* & $3(5,0)$ & $3(7,1)$ & $2(2,4)$ & $1(1,9)$ \\
\hline Pvk* & $4(6,7)$ & $4(9,5)$ & $5(5,9)$ & $1(1,9)$ \\
\hline Pvl* & $3(5,0)$ & $3(7,1)$ & $3(3,5)$ & $0(0,0)$ \\
\hline $\begin{array}{l}\text { Complexo } \\
\text { vivax** }\end{array}$ & $10(16,7)$ & $10(23,8)$ & $10(11,8)$ & $2(3,8)$ \\
\hline $\mathbf{P m} / \mathbf{P b}^{*}$ & $7(11,7)$ & $6(14,3)$ & $9(10,6)$ & $1(1,9)$ \\
\hline Pf* & $10(16,7)$ & $1(2,4)$ & $8(9,4)$ & $2(3,8)$ \\
\hline \multicolumn{5}{|l|}{ Antígeno - IgG } \\
\hline P. vivax & $7(11,7)$ & $9(21,4)$ & $18(21,2)$ & $8(15,4)$ \\
\hline P. malariae & $2(3,3)$ & $8(19,0)$ & $4(4,7)$ & $18(34,6)$ \\
\hline P. falciparum & $4(6,7)$ & $2(4,8)$ & $4(4,7)$ & $2(3,8)$ \\
\hline \multicolumn{5}{|c|}{$\begin{array}{l}\text { *Pvc - P. vivax clássico (Tipo 1) } \\
\text { Pvk -P. vivax variante VK247 (Tipo 2) } \\
\text { Pvl -P. vivax-like humano/P. simiovale } \\
\text { Pm/Pb - P. malariae/P. brasilianum } \\
\text { Pf - P. falciparum } \\
\text { **Complexo vivax - total de positivos par }\end{array}$} \\
\hline
\end{tabular}

Apesar das diferenças numéricas, não foi observada nenhuma diferença estatisticamente significante na análise comparativa das freqüências em ELISA e IFI, na amostra de bugios capturados no lado de SP e MS, de acordo com o sexo $(p>0,05)$. 


\subsubsection{Resultados das reações de ELISA e IFI na Amostra de Bugios de Acordo com a Faixa Etária}

A positividade em ELISA, de acordo com a faixa etária, nos macacos adultos de SP, foi maior com os peptídeos do "Complexo vivax" (19,4\%-14/102) em relação aos jovens e senis, sendo que para Pvc e Pvk a mesma foi de 6,9\% (5/102) e de 5,6\% (4/102) para $\mathrm{Pvl}$. Com os peptídeos $\mathrm{Pm} / \mathrm{Pb}$ e $\mathrm{Pf}$, a positividade também foi maior dentre os adultos em relação aos jovens e senis $(11,1 \%-8 / 102$ e 12,5\%-9/102, respectivamente).

Em IFI com o antígeno $P$. vivax e $P$. falciparum, a prevalência também foi maior entre os espécimes adultos (16,7\%-12/102 e 5,6\%-4/102, respectivamente). Com o antígeno de $P$. malariae foi maior entre senis e adultos (14,3\%-2/14 e 9,7\%$7 / 72$, respectivamente).

Tabela 28 - Freqüência de resultados positivos, segundo a faixa etária, para anticorpos da classe IgG contra a região repetitiva da Proteína Circumsporozoíta (CS) de plasmódio na reação de ELISA e contra formas sangüíneas de $P$. vivax, $P$. malariae e $P$. falciparum na reação de IFI. Amostra dos bugios capturados nas margens do rio Paraná, correspondentes ao lado de São Paulo, região de Presidente Epitácio, abril de 2000 a maio de 2001.

\begin{tabular}{|c|c|c|c|c|c|c|c|c|c|}
\hline \multicolumn{10}{|c|}{ São Paulo (n=102) } \\
\hline & \multicolumn{6}{|c|}{$\begin{array}{c}\text { Proteína CS - IgG } \\
\text { Pos. }(\%)\end{array}$} & \multicolumn{3}{|c|}{$\begin{array}{l}\text { Antígeno - IgG } \\
\text { Pos.(\%) }\end{array}$} \\
\hline F.etária & Pve* & Pvk $^{*}$ & Pvl* & C. vivax* & $\mathbf{P m} / \mathbf{P b}^{*}$ & $\mathbf{P f}^{*}$ & Pv" & $\mathbf{P m}^{*}$ & $\mathbf{P f}^{\dagger}$ \\
\hline $\begin{array}{l}\text { Juvenil } \\
(\mathrm{n}=16)\end{array}$ & $0(0,0)$ & $2(12,5)$ & $1(6,3)$ & $3(18,8)$ & $2(12,5)$ & $2(12,5)$ & $2(12,5)$ & $1(6,3)$ & $0(0,0)$ \\
\hline $\begin{array}{l}\text { Adulto } \\
(\mathrm{n}=72)\end{array}$ & $5(6,9)$ & $5(6,9)$ & $4(5,6)$ & $14(19,4)$ & $8(11,1)$ & $9(12,5)$ & $12(16,7)$ & $7(9,7)$ & $4(5,6)$ \\
\hline $\begin{array}{l}\text { Senil } \\
(n=14)\end{array}$ & $1(7,1)$ & $1(7,1)$ & $1(7,1)$ & $3(21,4)$ & $3(21,4)$ & $0(0,0)$ & $2(14,3)$ & $2(14,3)$ & $2(14,3)$ \\
\hline $\begin{array}{l}{ }^{*} \mathrm{Pvc}-P . \\
\mathrm{Pvk}-P . \\
\mathrm{Pvl}-P . \\
\mathrm{Pm} / \mathrm{Pb}- \\
\mathrm{Pf}-P . f a \\
{ }^{* *} \mathrm{Comple} \\
{ }^{\circ} \mathrm{Pv}-P, \mathrm{v}\end{array}$ & $\begin{array}{l}\text { vax cláss } \\
\text { vax varia } \\
\text { ax-like } \\
\text { malaria } \\
\text { iparum } \\
\text { o vivax- }\end{array}$ & $\begin{array}{l}\text { (Tipo 1) } \\
\text { nK247 } \\
\text { mano/P. si } \\
\text { P. brasilia }\end{array}$ & $\begin{array}{l}\text { ipo 2) } \\
\text { iovale } \\
\text { iom }\end{array}$ & , & & & & & \\
\hline
\end{tabular}


$\mathrm{Na}$ análise das freqüências para anticorpos CS nos macacos do MS, estratificada por faixa etária observou-se também maior prevalência para os peptídeos do "Complexo vivax" (10,5\%-10/137) entre os espécimes adultos, sendo 5,3\% (5/137) para Pvk, 3,2\% (3/137) para Pvc e 2,1\% (2/137) para Pvl. Com os peptídeos $\mathrm{Pf}$ e $\mathrm{Pm} / \mathrm{Pb}$, a positividade também foi maior dentre os adultos, $8,4 \%$ $8 / 137$ e 7,4\%-7/137, respectivamente.

Em IFI, as prevalências foram maiores dentre os adultos em relação aos jovens e senis, sendo $21,1 \%(20 / 95)$ para $P$. malariae, 16,8\% (16/137) para $P$. vivax e 6,3\% (6/137) para $P$. falciparum (Tabela 29$)$.

Tabela 29 - Freqüência de resultados positivos, segundo a faixa etária, para anticorpos da classe IgG contra a região repetitiva da Proteína Circumsporozoíta (CS) de plasmódio na reação de ELISA e contra formas sangüíneas de $P$. vivax, $P$. malariae e $P$. falciparum na reação de IFI. Amostras de bugios capturados nas margens do rio Paraná, correspondentes ao lado do Mato Grosso do Sul, região de Presidente Epitácio, abril de 2000 a maio de 2001.

\begin{tabular}{|c|c|c|c|c|c|c|c|c|c|}
\hline \multicolumn{10}{|c|}{ Mato Grosso do Sul (n=137) } \\
\hline & \multicolumn{6}{|c|}{$\begin{array}{c}\text { Proteína CS - IgG } \\
\text { Pos. (\%) }\end{array}$} & \multicolumn{3}{|c|}{$\begin{array}{c}\text { Antígeno - IgG } \\
\text { Pos.(\%) } \\
\end{array}$} \\
\hline F. etária & Pvc* $^{*}$ & Pvk* $^{*}$ & $\mathbf{P v l}^{*}$ & C.vivax* & $\mathbf{P m} / \mathbf{P b}^{*}$ & $\mathbf{P f}^{*}$ & $\mathbf{P v} \mathbf{v}^{*}$ & $\mathrm{Pm}^{*}$ & $\mathbf{P f}$ \\
\hline $\begin{array}{l}\text { Juvenil } \\
(n=14)\end{array}$ & $0(0,0)$ & $0(0,0)$ & $0(0,0)$ & $2(14,3)$ & $1(7,1)$ & $3(21,4)$ & $0(0,0)$ & $1(7,1)$ & $1(7,1)$ \\
\hline $\begin{array}{l}\text { Adulto } \\
(\mathrm{n}=95)\end{array}$ & $3(3,2)$ & $5(5,3)$ & $2(2,1)$ & $10(10,5)$ & $7(7,4)$ & $8(8,4)$ & $16(16,8)$ & $20(21,1)$ & $6(6,3)$ \\
\hline $\begin{array}{l}\text { Senil } \\
(\mathrm{n}=\mathbf{2 8})\end{array}$ & $0(0,0)$ & $1(3,6)$ & $1(3,6)$ & $2(7,1)$ & $1(3,6)$ & $1(3,6)$ & $7(25,0)$ & $1(3,6)$ & $0(0,0)$ \\
\hline \multicolumn{10}{|c|}{$\begin{array}{l}\text { *Pvc -P. vivax clássico (Tipo 1) } \\
\text { Pvk -P. vivax variante VK247 (Tipo 2) } \\
\text { Pvl -P. vivax-like humano/P. simiovale } \\
\text { Pm/Pb -P. malariae/P. brasilianum } \\
\text { Pf -P. falciparum }\end{array}$} \\
\hline
\end{tabular}


Apesar das diferenças numéricas, não foi observada nenhuma diferença estatisticamente significante na análise comparativa das frequências em ELISA e IFI de acordo com faixa etária, na amostra de bugios capturados no lado de SP e MS $(\mathrm{p}>0,05)$.

\subsubsection{Comparação entre os Resultados Positivos para Anticorpos contra Proteína CS (ELISA) e Contra Formas Assexuadas (IFI) de P. vivax, P. malariae e $P$. falciparum na amostra de bugios}

$\mathrm{Na}$ tabela 30 , estão demonstradas 13 amostras positivas que apresentaram anticorpos contra a proteína CS e contra formas sangüíneas para uma mesma espécie de plasmódio, sendo 5 amostras de bugios de SP e 8 do MS. Duas destas amostras reagiram contra duas espécies de plasmódio. A amostra $142 \mathrm{SP}$ reagiu com os antígenos de $\mathrm{Pf}(40)$ e $\mathrm{Pm}(80)$ e com os peptídeos Pf (1.013) e $\mathrm{Pm} / \mathrm{Pb}(0.487)$, respectivamente. A amostra $240 \mathrm{MS}$ reagiu com os antígenos Pv (40) e Pm (80) e com os peptídeos $\mathrm{Pvl}(0.250)$ e $\mathrm{Pm} / \mathrm{Pb}(0.857)$, respectivamente. 
Tabela 30 - Comparação entre os resultados positivos para a mesma espécie de Plasmodium, nas reações de IFI e ELISA, das amostras de bugios capturados nas margens do rio Paraná correspondentes aos lados de São Paulo e do Mato Grosso do Sul, região de Presidente Epitácio, abril de 2000 a maio de 2001.

\begin{tabular}{|c|c|c|}
\hline & IFI - IgG & ELISA - IgG \\
\hline $\begin{array}{l}\text { Amostra } \\
\mathbf{N}^{0} \text {. }\end{array}$ & $\begin{array}{c}\text { Antígeno - Formas sangüíneas* } \\
\text { (Título) }\end{array}$ & $\begin{array}{c}\text { Proteína CS }{ }^{* *} \\
\text { (Absorbância }-414 \mathrm{~nm} \text { ) }\end{array}$ \\
\hline \multicolumn{3}{|l|}{ São Paulo } \\
\hline 19 & $\mathrm{Pv}(40)$ & Pvk (1.002) \\
\hline 43 & Pv (40) & Pve $(0.857)$ \\
\hline 90 & Pv (40) & Pve (0.171) \\
\hline 142 & $\begin{array}{l}\operatorname{Pf}(40) \\
\operatorname{Pm}(40)\end{array}$ & $\begin{array}{l}\mathrm{Pf}(1.013) \\
\mathrm{Pm} / \mathrm{Pb}(0.487)\end{array}$ \\
\hline 111 & $\operatorname{Pm}(80)$ & $\mathrm{Pm} / \mathrm{Pb}(0.232)$ \\
\hline $\begin{array}{l}\text { Mato } \\
\text { Gross } \\
\text { do Su }\end{array}$ & 年 & \\
\hline 51 & Pv (40) & Pvl (0.255) \\
\hline 67 & Pv (40) & Pvk (0.487) \\
\hline 213 & Pv (40) & Pve (0.161) \\
\hline 240 & $\begin{array}{l}\text { Pv (40) } \\
\text { Pm (80) }\end{array}$ & $\begin{array}{l}\mathrm{Pvl}(0.250) \\
\mathrm{Pm} / \mathrm{Pb}(0.857)\end{array}$ \\
\hline 79 & Pf $(40)$ & Pf $(0.772)$ \\
\hline 26 & Pm (80) & $\mathrm{Pm} / \mathrm{Pb}(0.312)$ \\
\hline 29 & Pm (160) & $\mathrm{Pm} / \mathrm{Pb}(1.526)$ \\
\hline 211 & $\operatorname{Pm}(80)$ & $\mathrm{Pm} / \mathrm{Pb}(0.243)$ \\
\hline
\end{tabular}

* Pv - P. vivax, Pm - P. malariae e Pf - P. falciparum

**Pve - P. vivax clássico (Tipo 1)

Pvk - P. vivax variante VK247 (Tipo 2)

Pvl - P, vivax-like humano/P. simiovale

$\mathrm{Pm} / \mathrm{Pb}-\mathbf{P}$. malariae/P. brasilianum

Pf - P. falciparum 


\subsubsection{Comparação entre os Resultados Positivos para Anticorpos Contra Proteína CS (ELISA) e Contra Formas Assexuadas (IFI) de $P$. vivax, $P$. malariae e P. falciparum na Amostra Humana e de Bugios Capturados no lado de São Paulo}

Considerando a grande proximidade entre a população humana do Campinal e a população de bugios que habitava a mata ciliar do Rio do Peixe (SP) antes das inundações para formação do reservatório, neste item, encontram-se comparadas as freqüências dos resultados positivos para proteína CS e para formas assexuadas em ambas amostras, humana e de bugios, capturados no lado de São Paulo.

Quanto à prevalência para anticorpos contra proteína CS, em ELISA, ambas amostras, humana e de macacos, apresentaram porcentagem semelhante para 0 "Complexo vivax" (22,3\% e 19,6\%, respectivamente), não apresentando grandes diferenças nas respostas para Pvc, Pvk e Pvl. Para o peptídeo $\mathrm{Pm} / \mathrm{Pb}$ a prevalência foi maior nos bugios, em relação aos humanos (12,7\% e 3,8\%, respectivamente), o mesmo ocorreu com o Pf $(10,8 \%$ e 3,8\%, respectivamente) (Tabela 31$)$. 
Tabela 31 - Comparação entre a prevalência de anticorpos da classe IgG contra proteína CS na reação de ELISA e contra formas sangüíneas em reação de IFI na amostra humana do Campinal $(n=130)$ e dos bugios capturados no lado de São Paulo (n=102).

\begin{tabular}{|c|c|c|}
\hline & $\begin{array}{c}\text { Humanos - Campinal } \\
(\mathbf{n}=130) \\
\text { Pos. }(\%)\end{array}$ & $\begin{array}{l}\text { Bugios - São Paulo } \\
\text { (n=102) } \\
\text { Pos. (\%) }\end{array}$ \\
\hline \multicolumn{3}{|l|}{ Proteína CS-IgG } \\
\hline Pve* & $15(11,5)$ & $6(5,9)$ \\
\hline Pvk* & $4(3,1)$ & $8(7,8)$ \\
\hline Pvl* & $10(7,7)$ & $6(5,9)$ \\
\hline Complexo vivax ${ }^{* *}$ & $29(22,3)$ & $20(19,6)$ \\
\hline $\mathbf{P m} / \mathbf{P b}^{*}$ & $5(3,8)$ & $13(12,7)$ \\
\hline $\mathbf{P f}^{*}$ & $5(3,8)$ & $11(10,8)$ \\
\hline \multicolumn{3}{|l|}{ Antígeno - IgG } \\
\hline P. vivax & $28(21,5)$ & $16(15,7)$ \\
\hline P. malariae & 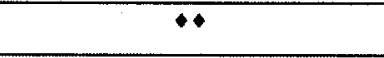 & $10(9,8)$ \\
\hline P. falciparum & $0(0,0)$ & $6(5,9)$ \\
\hline \multicolumn{3}{|c|}{$\begin{array}{l}\text { *Pve -P. vivax clássico (Tipo 1), Pvk -P. vivax variante VK247 (Tipo 2) } \\
\mathrm{Pvl}-P \text {. vivax-like humano/P. simiovale } \\
\mathrm{Pm} / \mathrm{Pb}-\text { P. malariae/P. brasilianum } \\
\mathrm{Pf}-P \text {. falciparum }\end{array}$} \\
\hline
\end{tabular}


Comparando a freqüência de anticorpos contra formas sangüíneas entre as duas amostras, foi observada que a prevalência para o antígeno de $P$. vivax foi maior tanto em humanos quanto macacos $(21,5 \%$ e $15,7 \%$, respectivamente) em relação ao antígeno de $P$. falciparum $(0,0 \%$ e $5,9 \%$, respectivamente). Não foi possível efetuar comparação entre a prevalência de anticorpos contra o antígeno de $P$. malariae entre as duas populações (humana/Campinal e bugios/SP), pois o teste de IFI foi realizado com apenas $30 \%$ da amostra humana (Tabela 31 ).

Na Figura 16 comparamos a distribuição das absorbâncias dos soros positivos humanos do Campinal e dos macacos capturados no lado de São Paulo com os 5 peptídeos. Verificou-se uma maior dispersão nas absorbâncias dos soros positivos de macacos em relação aos soros humanos, apresentando maiores absorbâncias para os peptídeos Pvc, Pvk e Pf, comparadas às absorbâncias encontradas nos soros positivos humanos, que foram menores com uma discreta dispersão.

Vale ressaltar que a prevalência para os peptídeos Pf e Pvk foi maior na amostra de macacos, em relação à amostra humana, além dos mesmos apresentarem maior dispersão, atingindo absorbâncias maiores que 1.0. 
Bugios (SP) x Humanos (Camp-SP)

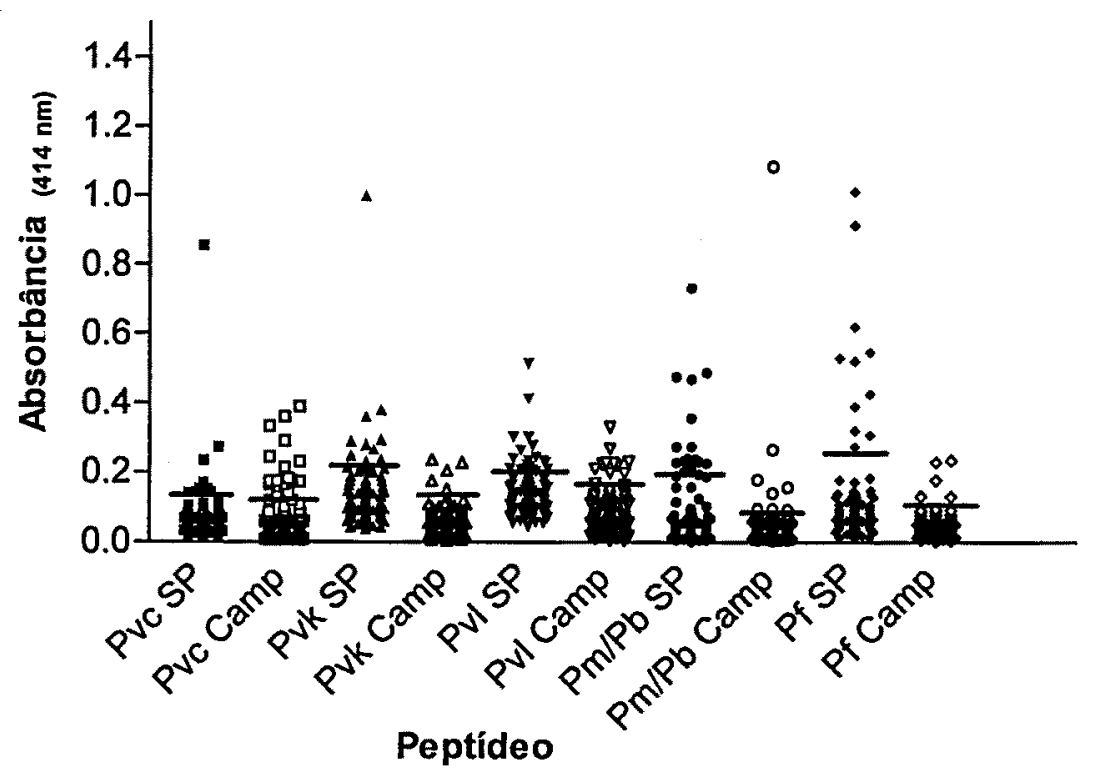

Figura 16 - Comparação entre a distribuição das absorbâncias, na reação de ELISA, para anticorpos da classe IgG contra a região repetitiva da Proteína CS nos soros da amostra de bugios capturados no lado de São Paulo e da amostra humana do Campinal/SP. Limite superior da barra: limiar de reatividade (M+3DP):

Macacos : Pvc $=0.148, \mathrm{Pvk}=0.244, \mathrm{Pvl}=0.251, \mathrm{Pm} / \mathrm{Pb}=0.223$ e Pf $=0.261$

Humanos: Pve $=0.135$, Pvk $=0.151, \mathrm{Pvl}=0.179, \mathrm{Pm} / \mathrm{Pb}=0.127$ e $\mathrm{Pf}=0.122$

$\mathrm{Na}$ amostra humana e de bugios capturados no lado de SP, não foi observada nenhuma diferença estatisticamente significante na análise comparativa das médias das absorbâncias obtidas com o peptídeo $\mathrm{Pm} / \mathrm{Pb}(\mathrm{p}>0,05)$. Houve diferença estatisticamente significante com os peptídeos Pvc $(<0,0001)$, Pvk ( $<<0,0001)$, Pvl $(p<0,0001)$ e $\operatorname{Pf}(p<0,0001)$. 


\section{DISCUSSÃO}

No exame parasitológico efetuado na população humana amostrada, não detectamos plasmódio nas lâminas de gota espessa/esfregaço, confeccionadas durante a coleta de sangue em janeiro de 2000 , confirmando a ausência de um quadro de transmissão de malária nas áreas do Campinal e do RLSP.

Os resultados do exame morfológico das lâminas de bugios capturados nos lados de São Paulo (SP) e Mato Grosso do Sul (MS) demonstraram a presença de plasmódios semelhantes ao $P$. vivax. A baixa parasitemia, o reduzido número de lâminas por espécime e dificuldades na foto-documentação das imagens não permitiram que os resultados obtidos fornecessem informações mais objetivas a respeito da morfologia destes plasmódios. No entanto, após exaustivas leituras das lâminas, com auxílio da equipe técnica de diagnóstico da SUCEN, confirmamos conjuntamente a presença de parasitos semelhantes ao $P$. vivax.

Os mesmos visualizados nas lâminas apresentaram, em sua maioria, diferenças no tamanho em relação às formas de $P$. vivax, apresentando trofozoítos pequenos e gametócitos com tamanhos irregulares. As lâminas que apresentaram formas duvidosas, em decorrência de má confecção das mesmas e/ou artefatos na coloração, foram consideradas negativas.

O encontro de formas semelhantes a gametócitos nas lâminas positivas dos bugios da área de estudo sugeriu a ocorrência de infecção malárica que pode ter evoluído até o estágio de transmissão vetorial, situação que os tornaria, potencialmente, fontes de infecção.

Alguns trabalhos relataram a presença de variações morfológicas em plasmódios de diferentes isolados humanos. EMIN (1914) identificou formas do parasito no sangue de peregrinos da Ásia e África, que foram classificados como $P$. vivax var. minuta. Stephens $(1914,1915)$, descreveu o $P$. tenue, isolado em pacientes da Índia, que apresentava semelhanças ao $P$. falciparum. Em recente pesquisa realizada em pacientes de Myanmar, foram identificados 2 tipos de $P$. malariae-like, um morfologicamente similar ao $P$. vivax var. minuta e outro ao $P$. tenue. Realizando análises das sequiências dos genes das subunidades de rRNA e do gene que codifica a 
proteína CS, foi verificada identidade gênica ao $P$. malariae, apesar das semelhanças com as duas espécies citadas (KAWAMOTO et al., 2002).

Esses resultados demonstraram a existência de variabilidade morfológica entre diferentes isolados geográficos de $P$. malariae, o que, certamente, dificultou a identificação de muitos casos de malária e sugeriram a classificação de isolados variantes como novas espécies.

Dados sobre infecções maláricas em macacos brasileiros, abrangendo o periodo de 1937 a 1990, indicaram $o$ P. brasilianum como a espécie geograficamente mais dispersa, infectando abundantemente macacos das Regiões Norte, Sudeste e Sul; o $P$. simium, secundariamente, apresentando uma dispersão mais discreta, ocorrendo apenas em macacos das Regiões Sudeste e Sul (DEANE, 1992).

Devido às semelhanças biológicas entre $P$. brasilianum e $P$. malariae (TALIAFERRO, 1932; COCHRANE et al., 1985; LAL et al.,1988a) e, P. simium e P. vivax (DEANE 1964; SEED et al., 1976), alguns autores sugeriram tratar-se dos mesmos parasitos sendo apenas encontrados em hospedeiros diferentes (COATNEY, 1971; DEANE, 1992). Os recentes estudos taxonômicos moleculares demonstraram que $P$. malariae e $P$. brasilianum são uma mesma espécie, apenas isoladas em hospedeiros diferentes. (LAL et al., 1988a, LAL e GOLDMAN, 1991, ESCALANTE et al., 1995); quanto ao $P$. simium ainda não existem evidências suficientes que comprovem sua identidade com o $P$. vivax.

O trabalho mais recente sobre infecção malárica em macacos foi realizado por FANDEUR et al. (2000) em uma área de inundação no Rio Sinnamary, na Guiana Francesa, onde foi verificada prevalência de 5,6\% (12/214) de $P$. brasilianum nos macacos capturados (Alouatta seniculus e Saguinus midas), por meio de exame parasitológico Estes resultados corroboram com as observações feitas por ARRUDA (1985), ARRUDA et al. (1989) e DEANE (1992) sobre o encontro de $P$. brasilianum em macacos da Amazônia. É importante ressaltar que, tanto neste estudo como no realizado por DEANE (1992), alguns parasitos não foram identificados (considerados apenas como Plasmodium sp.). DEANE não descartou a possibilidade da ocorrência de outras espécies de plasmódios ainda não identificadas na Floresta Amazônica. 
Pesquisa semelhante foi realizada com macacos capturados na área do reservatório da UHE de Serra da Mesa (Goiás) e macacos capturados em áreas de Mata Atlântica, porém não foram encontrados macacos infectados no exame parasitológico (DUARTE, 1998).

A detecção de plasmódios em macacos que habitam áreas de transição entre Mata Atlântica e Cerrado, complementa o conhecimento da malária simiana no território brasileiro, no entanto a elucidação dos aspectos morfológicos pendentes nesta pesquisa, deverá advir de novas tentativas de identificação destes parasitos; confeccionando um maior número de lâminas para cada novo espécime coletado e com isso aumentando a possibilidade de localização e documentação dos mesmos.

Na técnica de PCR, não ocorreram amplificações nas amostras de DNA da população humana com os "primers" correspondentes a seqüência gênero específica de 18S rRNA (ALBI01 e AL553), confirmando o resultado observado no exame parasitológico de gota espessa/esfregaço.

A ocorrência de infecção nos bugios foi confirmada pela amplificação de fragmentos de DNA com os "primers" ALBI01 e AL553 gênero específico, nas amostras de DNA de bugios capturados nos lados de SP e MS. Entretanto, como descrito anteriormente, os fragmentos apresentaram tamanhos maiores que os esperados.

Situação semelhante ocorreu com amostras de DNA de bugios que apresentaram fragmentos amplificados com os "primers" CS de $P$. vivax (AL60 e AL61), porém menores que o esperado.

É comum que fragmentos amplificados apresentem uma pequena variação no tamanho, entretanto os resultados observados mostraram uma variação maior que a normalmente esperada, principalmente nos produtos amplificados com os "primers" CS de $P$. vivax (AL60 e AL61), que poderiam sugerir amplificações inespecíficas. No entanto, somente a realização do seqüenciamento de DNA destes produtos de PCR, em etapa futura, possibilitará a verificação do grau de similaridade com as seqüências de plasmódio já descritas. 
Os "primers" utilizados na presente pesquisa, já testados em trabalho anterior da mesma autora, foram submetidos a reações com diferentes temperaturas de alinhamento ("anneling"), onde observamos que pequenas variações crescentes não possibilitaram a amplificação de DNA de controles positivos e das amostras positivas de bugios da área de estudo, portanto as reações foram efetuadas com as temperaturas preconizadas nos respectivos métodos, exceto na reação com os "primers" 18S rRNA (ALBO1 e AL553), na qual foi possível utilizar a temperatura de $45^{\circ} \mathrm{C}$, sendo que os fragmentos obtidos com $42^{\circ} \mathrm{C}$, de acordo com o método original, foram obtidos e confirmados à $45^{\circ} \mathrm{C}$.

Adicionalmente, a utilização dos "primers" CS de $P$. vivax permitem que os produtos amplificados sejam utilizados na técnica de hibridização com sondas específicas para a diferenciação das variantes de $P$. vivax (Pvc, Pvk e Pvl), segundo metodologia preconizada por Qari et al. (1993).

Com o intuito de certificarmos os resultados positivos obtidos no exame parasitológico e na técnica de PCR, as amostras de DNA correlatas foram submetidas aos métodos preconizados por SNOUNOU et al. (1993) e KIMURA et al. (1997) no Laboratório de Malária da SUCEN.

No método de "SNOUNOU" nenhuma amostra apresentou amplificação. No método de "Kimura" as amostras 157 MS, 191 MS e 199 MS, positivas com os "primers" 18S rRNA (ALB01 e AL553), amplificaram na primeira reação com os "primers" gênero-específico, e na segunda reação, com os espécie-específicos, sendo positivos para $P$. vivax, $P$. falciparum e $P$. vivax $+P$. falciparum (infecção mista), respectivamente.

Curiosamente, as amostras de DNA correspondentes às amostras positivas no exame de gota espessa, não amplificaram com os "primers" gênero específicos (ALBI01 e AL553) e também nos método de "Kimura" e "Snounou". Estes resultados negativos poderiam ser discutidos segundo duas situações: 1 - baixa parasitemia "versus" baixa sensibilidade dos "primers"; 2 - modificações na seqüência do gene correspondente ao $18 \mathrm{~S}$ rRNA, embora saibamos que as seqüências de DNA ribossômico são altamente conservadas, não podemos descartar a possibilidade da ocorrência de uma espécie nova ou uma "variante". 
Vale ressaltar que apenas a amostra a 157 MS apresentou fragmentos amplificados de tamanhos absolutamente coerentes nas reações de PCR, com os "primers" 18S rRNA (ALB01 e AL553), com aproximadamente 700 pb e, no método de "Kimura" com os "primers" espécie-específicos de $P$. vivax (100 pb).

Considerando que um método serviu como testemunho do outro, e após submetermos todas as 239 amostras de DNA de bugios ao método de "Kimura", elegemos como resultados verdadeiramente representativos para o nosso estudo àqueles apresentados pelas amostras positivas em ambos os testes (amostras 157MS, 191MS e 199MS).

Apesar das restrições encontradas nos métodos utilizados, conseguimos atingir o objetivo proposto dentro de um contexto epidemiológico, ou seja, a "visualização" de infecções por plasmódios em uma população de bugios a partir de marcadores de DNA genômico de plasmódios humanos. Talvez as diferenças observadas nos fragmentos amplificados obtidos $\mathrm{e}$ a grande porcentagem de resultados negativos associada à discordância com os resultados observados no exame parasitológico, correspondam à ineficiência destes marcadores na detecção de plasmódios simianos, a despeito das similaridades genômicas já descritas.

$\mathrm{Na}$ continuidade da pesquisa, serão necessários esforços para otimizar o método de PCR, levando em consideração: 1) o tipo de método utilizado e sua relação com a especificidade e sensibilidade (Nested-PCR, Multiplex, etc.); e 2) o tipo de marcador mais adequado para identificar a natureza destes parasitos.

$\mathrm{Na}$ análise epidemiológica que podemos inferir mediante aos resultados obtidos por meio da técnica de PCR somado aos do exame parasitológico, sugerimos a ocorrência de um quadro de transmissão de malária na população de bugios da área de estudo, cujo agente (s) etiológico (s) ainda não pode ser objetivamente identificado, porém os resultados observados sugeriram a presença de $P$. vivax e $P$. falciparum.

O envolvimento de $P$. falciparum em um ciclo de transmissão entre macacos do Novo Mundo foi anteriormente abordado por GOZALO et al. (1997), que encontraram respostas sorológicas contra os antígenos CS (NANP), MSP1 e SPf66, em soros de soros de macacos silvestres do gênero Saimiri, na região de floresta amazônica do Peru, sugerindo que os mesmos poderiam naturalmente se infectar 
com este plasmódio. Resultados semelhantes foram observados também por ARRUDA et al. (1989).

Sabemos das similaridades e da proximidade filogenética entre o $P$. falciparum e o $P$. reichenowi, plasmódio que infecta chimpanzés (macaco do Velho Mundo). A região repetitiva da proteína CS de $P$. reichenowi (NVNP) difere em apenas um aminoácido em relação à de $P$. falciparum (NANP e NVDP) (LAL e GOLDMAN, 1991) e; a análise filogenética da região conservada do gene CS das duas espécies também indicou grande proximidade entre as mesmas (ESCALANTE et al. 1995).

Estes resultados se somaram às análises anteriormente feitas no DNA ribossômico das duas espécies que indicaram que as mesmas são monofiléticas, sugerindo que o $P$. falciparum esteve associado aos ancestrais humanos desde a divergência com os grandes macacos (ESCALANTE e AYALA, 1994).

Estamos à frente de uma situação epidemiológica complexa e desconhecida, onde os seus diferentes componentes somente serão elucidados a partir da continuidade da pesquisa, envolvendo diferentes marcadores moleculares para detecção de plasmódios em seus hospedeiros humanos e simianos e nos vetores envolvidos neste ciclo de transmissão.

A presença de $P$. simium já havia sido anteriormente notificada em áreas de Mata Atlântica no Estado de São Paulo (DEANE, 1992), no entanto é de fundamental interesse a identificação molecular do plasmódio(s) presente(s) nos bugios de nossa área de estudo. Relembramos que futuramente os produtos amplificados serão submetidos às técnicas de seqüenciamento de DNA, juntamente com a técnica de hibridização com sondas específicas para diferenciação das variantes de $P$. vivax (Pvc, Pvk e Pvl), que será utilizada concomitantemente, com o objetivo de identificar as semelhanças e homologias entre o $P$. simium e o $P$. vivax. 
A reação de ELISA, com peptídeos sintéticos que mimetizam a porção repetitiva da Proteína Circumporozoíta (CS), em uma pesquisa epidemiológica, permite a observação de resposta sorológica ao esporozoíto, forma infectante do parasito e, portanto, indica se a população alvo está ou esteve em contato com anofelinos infectados por plasmódios.

Porém, vale ressaltar que um resultado positivo para proteína CS não indica necessariamente que o individuo desenvolveu a doença, pois, para seu prosseguimento é necessário que um número mínimo de esporozoítos consiga atingir os hepatócitos, segundo a literatura, em condições experimentais, seria de aproximadamente 100 formas (NUSSENZWEIG e NUSSENZWEIG, 1984).

Por se tratar de uma proteina com propriedades imunogênicas, o contato entre o homem (ou macaco) e mosquitos infectados, mesmo com uma carga parasitária abaixo do que chamaríamos de "carga infecciosa", gera ao longo do tempo, uma resposta imune que varia conforme o tempo de permanência no local e exposição aos vetores, mesmo na ausência de manifestação clínica da doença, portanto este parâmetro está relacionado diretamente com a endemicidade da doença. (PHILPOTT et al., 1990).

Enquanto a presença de anticorpos contra a proteína CS indica apenas o contato com esporozoítos, a presença de anticorpos contra formas sangüíneas (assexuadas) de plasmódio indica a existência, passada ou presente, de infecção malárica (CURADO, 1995).

Nosso objetivo na pesquisa foi verificar a prevalência de anticorpos, da classe IgG, nos soros de moradores nativos da área de estudo (Campinal), moradores do Reassentamento Lagoa São Paulo (RLSP) e nos macacos (bugios) da região (SP e MS), com a finalidade de observar respostas sorológicas aos possíveis contatos com esporozoítos, e também respostas sorológicas às possíveis infecções maláricas, já que a área apresenta história pregressa de malária.

Ambas reações, ELISA e IFI, foram anteriormente adaptadas e testadas em pesquisa semelhante da mesma autora, para detecção de anticorpos em soros humanos e de macacos (Duarte, 1998).

A ocorrência soros falsos - positivos nas reações de ELISA foi evitada após adotarmos como limiares de reatividade, para cada peptídeo, àqueles determinados 
nos cálculos das absorbâncias obtidas com soros negativos humanos e de bugios da própria área de estudo (“cut-off da área": Média+3DP). Desta forma, os limiares foram ajustados de acordo com as variações das absorbâncias dos soros negativos dos indivíduos (ou espécimes) residentes da área de estudo, conseqüentemente os resultados retrataram mais fielmente o perfil sorológico das populações estudadas face ao quadro epidemiológico da região.

Não foram realizados testes de especificidade, pois dispúnhamos de um volume pequeno de soro, suficiente apenas para realização das reações propostas. Em pesquisa semelhante, realizada anteriormente pela mesma autora, as seqüências dos 5 peptídeos utilizados no atual estudo foram comparadas, por meio do "BLAST at NCBI", com outras seqüências de aminoácidos, de origens diversas, já descritas e nenhuma homologia estatisticamente significante foi observada (DUARTE, 1998).

ARRUDA et al. (1989) verificaram em um ensaio de inibição que os peptídeos $\mathrm{Pm} / \mathrm{Pb}(\mathrm{NAAG})_{4}$ e $\quad$ o $\mathrm{Pf}(\mathrm{NANP})_{\mathrm{n}}$ apresentaram respostas espécie específicas. Mais recentemente, VOLNEY et al. (2002), realizando testes de inibição semelhante com os mesmos peptídeos ( $\mathrm{Pf}$ e $\mathrm{Pm} / \mathrm{Pb}$ ), também observaram alta especificidade dos anticorpos com o peptídeo correspondente.

Nos resultados da população humana amostrada, observamos uma significativa prevalência de anticorpos contra a proteína $\mathrm{CS}$, demonstrando que os habitantes desta área estiveram expostos aos esporozoítos de plasmódios.

A positividade mais expressiva foi observada nos residentes do Campinal, com alta prevalência de anticorpos contra os peptídeos do "Complexo vivax", onde verificamos a presença de respostas contra as 3 variantes em diferentes proporções, sendo o maior número de indivíduos positivos para Pvc. Detectamos também uma baixa freqüência de respostas contra $\mathrm{Pm} / \mathrm{Pb}$ e Pf. Este quadro corresponde à história epidemiológica do Campinal, onde os casos autóctones de malária ocorriam freqüentemente neste local, inclusive o último, notificado em 1993.

Os participantes da amostra do Campinal, em sua maioria, não relataram deslocamentos para áreas endêmicas, o fluxo migratório observado ocorre principalmente entre as regiões vizinhas do Mato Grosso do Sul e as cidades próximas, no lado paulista. A população é sedentária, sendo a principal atividade a 
agricultura e a pescaria (como lazer), portanto as prevalências encontradas representam um fenômeno local.

No RLSP, a positividade foi bem menos expressiva, porém acompanhando a tendência observada no Campinal, onde o número de indivíduos positivos para anticorpos contra CS foi maior com os peptídeos do "Complexo vivax", sendo a maior prevalência observada para o peptídeo Pvl. Houve a presença de respostas para o peptídeo $\mathrm{Pf}$ e em menor proporção $\mathrm{Pm} / \mathrm{Pb}$.

A população do RLSP, por conceito, é heterogênea, apresentando em sua composição habitantes oriundos de diversas localidades. Na população amostrada verificamos que grande parte das pessoas veio de regiões próximas, entretanto uma parcela menor se refere a posseiros, "sem-terra", pessoas que vieram de outros assentamentos e de outros Estados, no entanto nenhum dos participantes relatou deslocamento para áreas endêmicas. Portanto a positividade observada na população amostrada do RLSP pode ser atribuída a contatos com anofelinos infectados na área de estudo ou nas adjacências, refletindo o quadro epidemiológico da região.

A presença de respostas contra variantes de $P$. vivax na população humana amostrada corrobora com os resultados dos estudos realizados no Brasil sobre a dispersão destas cepas em áreas endêmicas e não endêmicas.

Evidências sorológicas da presença das variantes foram encontradas em populações do Estado do Pará e Acre (KREMSNER et al., 1992; OLIVEIRA et al. 1995b; MARRELLI et al., 1997).Um estudo soroepidemiológico realizado em áreas de ocorrência de malária autóctone na Mata Atlântica Paulista, notificou também a presença de anticorpos contra Pvk e Pvl (CURADO et al, 1997).

Possivelmente, as variantes de $P$. vivax tenham se dispersado há muito tempo, porém são poucos os conhecimentos a respeito de sua epidemiologia e relações com sintomatologia (MACHADO e POVOA, 2000), sendo que a presença das mesmas em áreas não endêmicas também é um fenômeno epidemiológico a ser elucidado.

Outro aspecto que nos chamou a atenção foi a presença de soros reativos com mais de um peptídeo, não só entre os peptídeos do "Complexo vivax", mas também com os peptídeos $\mathrm{Pf}$ e $\mathrm{Pm} / \mathrm{Pb}$. No Campinal o número destes soros foi maior que RLSP. Estes resultados indicaram que os moradores de ambas localidades entraram 
em contato, em algum momento, com mosquitos infectados com as diferentes espécies e variantes de plasmódio.

A possibilidade de reação cruzada entre os peptídeos CS é pouco provável, pois as seqüências de aminoácidos dos mesmos são diferentes entre si. Um único trabalho descreveu a ocorrência de reação cruzada entre os peptídeos $\mathrm{CS}$ de $\mathrm{Pm} / \mathrm{Pb}$ $\left[(\mathrm{NAAG})_{4}\right]_{4}$ e de PvK (ANGAGNQPG) $)_{4}$ em soros de índios no Brasil (COCHRANE et al., 1990).

$\mathrm{Na}$ população humana amostrada nenhum soro reagiu positivamente com ambos os peptídeos $\mathrm{Pm} / \mathrm{Pb}$ e Pvk. Se considerada válida a existência de reação cruzada entre as respostas contra estes plasmódios, a mesma parece ter ocorrido em baixa freqüência nesta pesquisa.

Na distribuição das absorbâncias dos soros positivos verificamos apenas uma amostra altamente reativa para o peptídeo $\mathrm{Pm} / \mathrm{Pb}$, apresentando absorbância de 1.085. Este resultado nos chamou a atenção, pois se trata de uma amostra pertencente a uma moradora do Campinal que nunca saiu da região e, portanto a resposta imunológica corresponde a uma ocorrência local de contato com anofelinos infectados com $\mathrm{Pm} / \mathrm{Pb}$. Considerando que as identidades antigênicas, biológicas e genéticas determinam que $P$. malariae e $P$. brasilianum se referem a uma espécie única, a prevalência encontrada na população humana aponta fortemente para uma interação local entre mosquitos, humanos e macacos.

$\mathrm{Na}$ análise da prevalência de anticorpos contra CS entre grupos definidos por sexo, faixa etária e ocupação, e entre as duas localidades, não foram identificadas associações ou diferenças estatisticamente significantes. Entretanto, observamos correlação direta entre o tempo de residência e a positividade dos soros tanto no Campinal quanto no RLSP ( $\mathrm{p}<0,001)$.

No Campinal, a presença de respostas às variantes do "Complexo vivax" foi acentuada no grupo de moradores que estão na área há mais de 10 anos, sendo que respostas contra o peptídeo Pvk só apareceram na última faixa. Para as demais faixas, observamos baixa positividade para os peptídeos Pvc e Pvl, sendo que não houve positividade nos soros de indivíduos residente a menos de um ano na área. 
No RLSP, as respostas contra os peptídeos do "Complexo vivax" acompanharam a tendência observada no Campinal, porém com um menor número de positivos. A faixa dos residentes, com mais de 21 anos na área, apresentou o maior número de positivos, sendo observadas respostas contra os três peptídeos (Pvc, Pvk e Pvl); os positivos para Pvc e Pvk só ocorreram na mesma. Nas demais faixas, foi observada baixa positividade para Pvl. Os indivíduos que residiam há menos ou até 5 anos, não apresentaram positividade para os peptídeos do "Complexo vivax".

Em relação às respostas observadas contra os peptídeos CS de $\mathrm{Pf}$, no Campinal e no RLSP, os indivíduos positivos para o mesmo habitam a área há mais de 11 anos.

Diferentemente ao ocorrido com o $P$. falciparum, observou-se dentre os residentes há menos de 1 ano, positividade para o peptídeo $\mathrm{Pm} / \mathrm{Pb}$, em ambas localidades. Curiosamente, nas faixas de 2-5 e 6-10, os residentes foram negativos e, indivíduos positivos apareceram na faixa de 11-20, em ambas localidades.

Os resultados acima indicaram a presença de respostas antigas e recentes contra anticorpos CS nesta população, sugerindo que os contatos com anofelinos infectados promovem a resposta imune da população local, independentemente do surgimento de casos.

A ausência de resultados positivos para Pvk e Pf entre os indivíduos que residem até10 anos e paralelamente, a presença de positivos nos que residem há mais de 10 anos, em ambas localidades, podem sugerir que estes parasitos não estejam circulando na região.

A freqüência de anticorpos contra formas sangüíneas de $P$. vivax, em reação de IFI, na população humana amostrada, foi alta no Campinal e no RLSP, no entanto, o título dos anticorpos nos soros positivos foi baixo (até 160).

Não foram identificadas associações ou diferenças estatisticamente significantes nas análises das frequiências de anticorpos contra o antígeno de $P$. vivax, entre os grupos e entre as duas localidades, considerando as seguintes variáveis epidemiológicas: sexo, faixa etária e ocupação.

Quanto ao tempo de residência na área, observamos no Campinal a presença de um indivíduo positivo para o antígeno $P$. vivax, que reside a menos de um ano no 
local, e 1 positivo na faixa de 2-5 anos. Nas faixas de 6-10, 11-20 e $>21$ anos no local, a tendência de positividade foi crescente. No RLSP, não ocorreu positividade entre os indivíduos residentes há menos de um ano, enquanto que nas demais faixas os resultados foram semelhantes com aos descritos no Campinal.

Estes resultados sugerem que estes indivíduos desenvolveram infecção, em algum momento, talvez em situações passadas de transmissão, pois os mesmos apresentaram resultados negativos no exame parasitológico e na reação de PCR, no entanto, não podemos desconsiderar a possibilidade de ocorrência de casos assintomáticos em períodos anteriores a nossa pesquisa.

Não ocorreram respostas contra o antígeno de $P$. falciparum na população humana de ambas as localidades, Campinal e RLSP, este resultado associado aos resultados da prevalência de anticorpos contra $\mathrm{CS}$ de $\mathrm{Pf}$, onde a mesma foi observada somente nos residentes mais antigos, reforça a idéia que este plasmódio realmente não está circulando na população humana da área de estudo.

A quantidade de antígeno de $P$. malariae não foi suficiente para realizarmos o teste da totalidade da amostragem humana, entretanto dentre as amostras testadas (30\% da totalidade +7 amostras positivas em ELISA com o peptídeo $\mathrm{Pm} / \mathrm{Pb}$ ), apenas 1 foi positiva até o título de 160 (positiva também em ELISA).

Apesar a baixa frequêencia de soros positivos para CS e formas sangüíneas de $P$. malariae, a presença de um soro altamente positivo para $\mathrm{Pm} / \mathrm{Pb}$ de uma antiga residente do Campinal, e a detecção de um soro positivo, na reação de IFI, sugerem a circulação desta espécie na população humana da área de estudo.

Comparando os resultados dos soros positivos da população humana amostrada, nos testes de ELISA e IFI, observamos em alguns soros, relação entre as respostas contra CS e formas sangüineas de P.vivax, principalmente no Campinal e em menor proporção do RLSP. Estes dados indicam significativa similaridade nas respostas, sugerindo o contato destes indivíduos com plasmódios e a ocorrência de infecções maláricas, possivelmente assintomáticas e com parasitemia sub-patente. 
Em resumo, os resultados sorológicos demonstraram que as populações humanas de ambas localidades mantiveram contato com esporozoítos, mesmo em períodos de ausência de casos. O desenvolvimento gradual de resposta sorológica contra a proteína CS, possivelmente se deu por meio de exposições constantes a mosquitos infectados com baixas cargas de esporozoítos, insuficientes para dar prosseguimento à infecção. Esta situação justificaria a presença de anticorpos contra CS concomitante a ausência de infecções maláricas patentes. Sendo que a manutenção deste quadro epidemiológico se explicaria baseada em duas hipóteses: a presença de portadores assitomáticos; ou o envolvimento de bugios no ciclo de transmissão, atuando como reservatórios dos parasitos.

Adicionalmente, relembramos que o último caso autóctone foi notificado em 1993, portanto, podemos concluir que, no momento em que foi realizada a coleta de sangue da população (janeiro/2000), não existia uma situação patente de transmissão de $P$. vivax. Para elucidar os diversos aspectos decorrentes de nossa investigação seria necessária a continuidade da pesquisa, estruturada em um modelo longitudinal de estudo, onde a população fosse acompanhada, com exames periódicos para deteç̧ão de parasitos da malária em concomitante aos testes sorológicos.

$\mathrm{Na}$ amostra de bugios da área de estudo verificamos situação semelhante à observada na população humana, onde um significativo grau de respostas contra a proteina CS indica o contato desta população com esporozoítos de plasmódio.

Nos macacos capturados no lado de SP, observamos expressiva positividade entre os peptídeos do "Complexo vivax" (19,6\%), sendo o maior número de espécimes positivos com o peptídeo Pvk, seguido de Pvl e Pvc. Nos macacos capturados no lado do MS, a maior prevalência também foi para a variante Pvk.

Com os peptídeos $\mathrm{Pm} / \mathrm{Pb}$ e $\mathrm{Pf}$ a positividade foi maior dentre os macacos de SP $(12,7 \%$ e $10,8 \%$, respectivamente) em relação aos macacos do MS (7,3\% para ambos os peptídeos).

Considerando a distribuição territorial destes animais e a presença do rio Paraná como divisor de ambientes, as populações amostradas envolvidas pertencem a duas áreas isoladas e com características ecológicas distintas. Entretanto, os resultados gerais da pesquisa de anticorpos contra $\mathrm{CS}$ indicaram que ambas 
populações sofreram desafios por esporozoítos do "Complexo vivax", $P$. malariae/P.brasilianum e $P$. falciparum, de forma semelhante.

As respostas sorológicas para CS corroboram na caracterização de um quadro de transmissão nos habitats destes macacos, confirmando o contato dos mesmos com a fauna anofélica local, pois sabemos que os bugios delimitam seus territórios em função de presença de água e alimentos. Os territórios podem abranger alguns quilômetros, de acordo com as características geográficas de cada área associadas às necessidades de sobrevivência de cada grupo (AURICCHIO, 1995).

Um significativo número de soros de bugios positivos reagiu com mais de um peptídeo, indicando que estes animais foram desafiados por diferentes espécies e variantes de plasmódios. Destes, três apresentaram-se reativos para $\mathrm{Pm} / \mathrm{Pb}$ e $\mathrm{Pvk}$, o que, segundo Cochrane et al. (1990), poderia ser uma reação cruzada entre os mesmos, porém pela baixa freqüência na amostra total de bugios e pela ausência desta situação na amostra humana preferimos desconsiderar esta possibilidade.

$\mathrm{Na}$ distribuição das absorbâncias dos soros positivos, verificamos que algumas amostras apresentaram alta reatividade, com picos de até 1.2, exceto os soros positivos para Pvl, que apresentaram uma dispersão mais discreta (0.2-0.6).

$\mathrm{Na}$ análise da distribuição da positividade entre os grupos para anticorpos contra CS, segundo as variáveis sexo e faixa etária, não foram identificadas associações ou diferenças estatisticamente significantes.

A freqüência de anticorpos contra formas sangüíneas de plasmódio, em reação de IFI, nos macacos de SP, foi mais alta com o antígeno de $P$. vivax em relação ao antígeno de $P$. falciparum. Nos macacos do MS observamos a mesma tendência. $\mathrm{O}$ título dos soros positivos foi baixo, não ultrapassando a diluição de 1:40 (positivos no limiar de reatividade). $\mathrm{Na}$ análise da prevalência de anticorpos contra os antígenos de $P$. vivax e $P$. falciparum, entre os grupos definidos por sexo e faixa etária, e entre as localidades, não foram identificadas associações ou diferenças estatisticamente significantes. 
Estes resultados indicaram que, em algum momento, os espécimes positivos geraram resposta imune contra formas sangüíneas de $P$. vivax e P. falciparum.

Em relação ao antígeno de $P$. malariae, a positividade foi de $9,8 \%$ e $16,1 \%$ nos macacos de SP e MS, respectivamente; sendo que três soros atingiram o título de 320 , não deixando dúvidas quanto à ocorrência de uma infecção por esta espécie de plasmódio.

Comparando os resultados dos soros positivos da população amostrada nos testes de ELISA e IFI, observamos relação entre as respostas contra CS e formas sangüíneas de $P$. vivax, $P$. malariae e $P$. falciparum, sugerindo o contato com esporozoitos e sinais sorológicos decorrentes da infecção por uma mesma espécie de plasmódio nos espécimes positivos.

Não comparamos os resultados de sorologia com o exame parasitológico, pois os mesmos podem refletir contatos com os agentes e infecções que ocorreram em diferentes períodos. Citamos apenas que, das amostras positivas no exame parasitológico e na sorologia, observamos que 2 amostras que apresentaram formas semelhantes a plasmódios em gota espessa (178 SP e $121 \mathrm{MS})$ e foram positivas para $\mathrm{Pm} / \mathrm{Pb}$ na reação de ELISA. Da mesma forma, a amostra $244 \mathrm{MS}$ foi positiva na gota espessa e na reação de IFI, com o antígeno de $P$. vivax.

O caráter inédito dos resultados observados na população de bugios da área de estudo, suscita a ocorrência de quadros epidemiológicos onde a malária humana e simiana se mesclam, em uma situação de transmissão silenciosa, na qual, pouco se sabe sobre a sua dinâmica e os vetores envolvidos na mesma. Neste momento podemos comparar nosso estudo com situações epidemiológicas semelhantes, anteriormente relatadas, em trabalhos anteriores correlatos.

ARRUDA et al.(1989) realizaram um estudo de malária em tribos indígenas e macacos silvestres na região do Alto Xingu, no qual observaram alta prevalência de anticorpos contra formas sangüíneas de $P$. vivax,$P$. malariae e $P$. falciparum, e contra proteína CS de $P$. brasilianum/P.malariae, $P$. vivax "clássico" e $P$. falciparum nos soros de índios e de 28 macacos silvestres (bugios - Alouatta sp. e macacos-de-cheiro - Saimiri sp.). Em 13 macacos criados como animais de estimação, também foi verificada alta positividade. Tais dados foram considerados 
como fortes indicativos da existência de uma interação entre a malária simiana e humana, naquela situação epidemiológica.

A presença de anticorpos das classes IgM e IgG contra MSP1, SPf66 e CS de $P$. falciparum foi observada em macacos (Saimiri sciureus macrodon) capturados na floresta amazônica do Peru. A resposta para estes antígenos apontaram fortemente para a ocorrência de infecção por $P$. falciparum nestes animais. A proteína CS indicou o contato com mosquitos infectados com esporozoitos desta espécie. A proteína recombinante MSP1, que representa parte de uma proteína dos merozoítos, altamente conservada entre as diversas cepas já isoladas de $P$. falciparum, é um antígeno espécie-específico (BLACKMAN et al., 1990); e finalmente o antígeno SPf66 presente somente em formas assexuadas do parasito, corroboram para a hipótese de ocorrência de infecção por este plasmódio. Os autores discutem a possibilidade de assintomatologia, uma vez que, nenhum dos macacos considerados no estudo apresentou sinais de malária (GOZALO et al., 1997).

Resultados similares também foram observados em bugios (Alouatta caraya) capturados na região da UHE de Serra da Mesa (região de Cerrado, norte do Estado de Goiás), onde os espécimes positivos apresentaram baixos niveis de anticorpos IgG e IgM (40 e 80) contra os antígenos de $P$. falciparim e $P$. malariae. Um soro positivo atingiu o título de 1:5.120 (IgG) com o antígeno de $P$. falciparum, sugerindo a ocorrência de infecção por esta espécie. No mesmo estudo, foram observados títulos de até 1:320 para anticorpos contra o antígeno sangüíneo de $P$. vivax em bugios (Alouatta fusca) da Mata Atlântica do Estado de São Paulo. Anticorpos contra proteína CS do "Complexo vivax", $\mathrm{Pm} / \mathrm{Pb}$ e $\mathrm{Pf}$ também foram verificados em diferentes proporções nos macacos da Serra da Mesa e da Mata Atlântica (DUARTE, 1998).

VOLNEY et al. (2002), realizaram uma pesquisa soroepidemiológica na Guiana Francesa, envolvendo população humana e simina, onde encontraram alta freqüência de anticorpos contra formas sangüíneas de $P$. malariae, $P$. falciparum e $P$. vivax em 113 macacos (81 Alouatta seniculus macconnelli, 29 Saguinus midas midas e 3 Pithecia pithecia, macacos exclusivamente amazônicos). E demonstrou também a presença de altos níveis de anticorpos contra CS de $\mathrm{Pm} / \mathrm{Pb}, \mathrm{Pf}, \mathrm{Pvc}$, Pvk e Pvl, na 
população humana e simiana, ressaltando os resultados dos bugios que foram bastante significativos para a espécie presente naquela região, Alouatta senicullus

Em época anterior às inundações para a formação do reservatório da UHE de Porto Primavera, os bugios capturados no lado de São Paulo, viviam nas matas ciliares, ao longo da margem direita do rio Paraná, em áreas próximas ao Campinal.

Considerando que a população humana (Campinal) e bugios (SP), conviviam proximamente e possivelmente estavam expostas às mesmas populações de anofelinos, realizamos a comparação dos resultados sorológicos com a finalidade de levantarmos evidências sobre a relação entre a malária humana e simiana.

As freqüências de respostas sorológicas para os peptídeos do "Complexo vivax" foram semelhantes em ambas populações amostradas, ocorrendo Pvc, Pvk e Pvl em diferentes proporções, entretanto a maior positividade foi observada para os peptídeos Pvc e Pvl na amostra humana, e Pvk na amostra de bugios.

Estes resultados conferem grande similaridade nas respostas observadas para a espécie $P$. vivax em ambas as populações.

Com o peptídeo Pf, observamos maior positividade na amostra de bugios em relação à amostra humana do Campinal. E em IFI, com o antígeno de $P$. falciparum foi verificada prevalência de anticorpos nos bugios e ausência de positivos na amostra humana do Campinal para este antígeno.

Estes dados sugerem que a população humana, apesar de exposta aos contatos com esporozoítos de $P$. falciparum não desenvolve infecção, ao contrário da população de bugios, que apresentou sinais sorológicos de desenvolvimento da doença. Estes resultados associados ao resultado de 2 amostras de bugios positivos para $P$. falciparum no PCR, reforçam a possibilidade da presença do mesmo na população de macacos da região.

Com o peptídeo $\mathrm{Pm} / \mathrm{Pb}$, a positividade foi mais alta nos bugios de SP em relação à população humana do Campinal. Entretanto a amostra que apresentou alto nível de anticorpos contra o peptídeo foi de uma moradora do Campinal, sugerindo que os esporozoítos desta espécie estaria circulando entre as duas populações, humana e simiana, apesar da ausência de casos de $P$. malariae na região (comunicação pessoal/SUCEN Regional de Presidente Prudente). A freqüência de 
anticorpos contra formas sangüíneas nos macacos de SP e a presença de um único soro humano positivo para o mesmo antígeno corroboram com esta hipótese.

Comparando a distribuição das absorbâncias dos soros positivos humanos e dos bugios, verificamos diferenças estatisticamente significantes nos níveis de anticorpos contra os peptídeos do "Complexo vivax" e Pf, indicando que os bugios são mais intensamente desafiados pelos mesmos. E uma igualdade nas respostas para o peptídeo $\mathrm{Pm} / \mathrm{Pb}$, sugerindo que ambas populações estiveram igualmente expostas a esta espécie. No entanto, é importante relembrar que estes resultados, não indicam necessariamente que os contatos com esporozoítos evoluíram para um quadro de infecção.

A presença de anticorpos em populações humana e de macacos, simultaneamente foi observada no trabalho de ARRUDA et al. (1989), que verificou respostas sorológicas contra a proteína $\mathrm{CS}$ e antígenos de formas sangüíneas de $P$. falciparum, $P$. malariae e $P$. vivax em índios e macacos silvestres de mesma área. Devido às similaridades entre $P$. malariae $e P$. brasilianum e as evidências apresentadas no trabalho, os autores aventaram a possibilidade de relação entre a malária humana e simiana em função das respostas encontradas em naquelas populações, entretanto não discutiram sobre os resultados da sorologia dos macacos para $P$. vivax e $P$. falciparum.

VOLNEY et al. (2002), em pesquisa sorológica conduzida em áreas malarígenas da Guiana Francesa, observaram a presença de anticorpos em populações humanas de índios e descendentes de escravos e em macacos da mesma região. O resultado que mais chamou a atenção foi alta prevalência de anticorpos contra formas sangüíneas de $P$. falciparum nos macacos, comparados com a população humana. A presença de anticorpos contra peptídeos do "Complexo vivax" e contra $\mathrm{Pm} / \mathrm{Pb}$ sugeriram os macacos são freqüentemente picados por vetores infectados por esporozoítos de espécies de plasmódio que infectam humanos, sugerindo uma situação de transmissão envolvendo simultaneamente humanos e primatas neotropicais. 


\section{Considerações Finais}

As análises que realizamos até o momento nos forneceram indicativos da existência de dois quadros epidemiológicos distintos, um sendo o reflexo da história pregressa da malária humana na região e o outro, a malária que ocorre nas populações de bugios, que pode estar relacionada ao quadro humano de transmissão, ou não.

Não podemos afirmar que as respostas imunes observadas em ambas populações se correlacionem diretamente, pois ainda não foi possível identificar, com clareza, a natureza dos agentes, os mecanismos de transmissão dos mesmos em macacos silvestres, bem como os vetores competentes neste quadro epidemiológico.

Os indícios da ocorrência de infecções humanas, observados nos resultados da IFI com antígenos de formas sangüíneas de $P$. vivax, a correlação dos mesmos com a prevalência observada para os peptídeos do "Complexo vivax", em ELISA, em indivíduos que residiam há pouco tempo na área de estudo, são fortes indicativos da ocorrência de casos assintomáticos e da presença de reservatórios humanos. Entretanto a elucidação destes aspectos permanece na dependência do prosseguimento de pesquisas que comprovem ou não esta hipótese.

Alguns trabalhos reportam informações atuais e fundamentais sobre o assunto.

CURADO et al., (1997) em um estudo soroepidemiológico conduzido em populações humanas da Mata Atlântica Paulista, observaram alta prevalência de anticorpos contra antígenos sangüíneos de $P$. vivax e $P$. malariae, que sugeriram a ocorrência de quadro assintomático, envolvendo indivíduos que poderiam atuar como reservatórios de plasmódios humanos e/ou simianos.

CURADO (2003) realizando estudo epidemiológico na população humana do Parque Estadual de Intervales (região do Vale do Ribeira, Mata Atlântica paulista), detectou, por meio de PCR, a presença de portadores assintomáticos, dentre indivíduos que apresentaram resultados positivo para anticorpos da classe IgM contra $P$. vivax e $P$. malariae, no teste de IFI.

Em região Amazônica, ALVES et al. (2002), verificaram alta prevalência de infecções assintomáticas por $P$. vivax e $P$. falciparum em populações ribeirinhas no 
Estado de Rondônia e discutiram esta situação frente a atual estratégia de controle da malária que trata somente pacientes sintomáticos. CAVASINI et al. (2000) pesquisando a prevalência de $P$. malariae em Rondônia por meio de da técnica PCR, verificaram que o mesmo aparece associado em infecções por $P$. vivax e $P$. falciparum, não sendo identificado pelo método de diagnóstico convencional, caracterizando um quadro de assintomatologia e sub - notificação para este parasito.

Em áreas com história pregressa da doença, com a presença de anofelinos e uma situação de risco potencial de re-introdução da malária, a discussão das medidas preventivas devem abordar as principais implicações dos quadros de transmissão assintomáticos.

Em nossa área de estudo, como dito anteriormente, foi observado o recrudescimento dos criadouros de anofelinos, o conseqüente aumento da densidade de espécies antropofilicas $A n$. darlingi e An. albitarsis, e de algumas espécies vetoras com hábitos silvestres como o An. galvaoi e An. rondoni, após estabilização do lago formado pelo reservatório da UHE. As áreas de florestas remanescentes ou secundárias, entremeando as habitações concorrem para o repouso das fềmeas de anofelinos, que se abrigam e se dispersam em busca de alimento. $O$ repasto sangüíneo nestas áreas certamente se intensificará sobre a população humana e em concomitante sobre os bugios que ainda habitam aquela área, apesar da grande maioria de macacos ter sido transferida para áreas de reserva florestal no Estado do Mato Grosso do Sul.

Este quadro associado ao grande fluxo de pessoas que circulam nas vias de acesso entre os Estados de São Paulo e Mato Grosso do Sul, indica uma situação propícia para o ressurgimento da malária na região, que deve ser acompanhada para que futuros problemas sejam evitados.

A competência e a capacidade das espécies silvestres de anofelinos da área de estudo ainda é desconhecida, portanto não sabemos quais vetores estão envolvidos no quadro de malária simiana, e se os mesmos poderiam atuar na transmissão da humana.

Até onde sabemos, a única espécie comprovadamente vetora de plasmódios simianos é o An. (Kerteszia) cruzii, responsável pela transmissão do $P$. simium e $P$. brasilianum, em regiões de Mata Atlântica do Sudeste e Sul (DEANE, 1992). 
Para a elucidação dos mecanismos de transmissão envolvidos nesta situação epidemiológica particular, serão necessárias pesquisas entomológicas mais complexas, que identifiquem as espécies vetoras envolvidas e a utilização da técnica de PCR para identificação da infecção nos anofelinos.

Apesar das diferenças biogeográficas, os resultados de pesquisas realizadas por ARRUDA et al. (1989), GOZALO et al. (1997) e VOLNEY et al. (2002), apresentam grande semelhança com os nossos dados, suscitando aspectos comuns da malária simiana em diferentes populações de macacos do Novo Mundo.

Os resultados do PCR indicaram a presença de plasmódios nos bugios da área de estudo, entretanto os produtos amplificados das amostras positivas suscitaram dúvidas que só serão respondidas após o seqüenciamento de DNA e a utilização de novos marcadores em estudos futuros. Os dados indicaram preliminarmente que as espécies envolvidas são semelhantes a $P$. vivax e $P$. falciparum.

Sabemos que diferentes isolados de plasmódio podem apresentar variações morfológica, biológicas e moleculares, como discorrido ao longo desta dissertação. LI et al., (2001) em estudos experimentais, verificaram que cepas de $P$. vivax do Velho Mundo e do Novo Mundo se comportam diferentemente quando introduzidas em An. albimanus sugerindo que, na natureza, de acordo com as relações estabelecidas com os vetores, ocorram processos de adaptação, originando variações entre isolados de diferentes partes do mundo. Esta hipótese corrobora com àquela proposta por COATNEY (1971), segundo a qual o P. brasilianum e o P.simium seriam cepas de $P$. malariae e $P$. vivax, respectivamente, adaptadas aos macacos do Novo Mundo; se considerarmos que vetores, portadores destes isolados geográficos, apresentassem a capacidade de transmiti-los a primatas não humanos.

A continuidade desta linha de pesquisa poderá trazer importantes respostas sobre os mecanismos de interação dos plasmódios em hospedeiros humanos e simianos, bem como esclarecer pontos obscuros da relação evolutiva dos parasitas da malária. 


\section{CONCLUSÕES}

1 - Os resultados negativos, observados no exame parasitológico e nas reações de PCR, indicaram a ausência de um quadro patente de transmissão de malária humana na área de estudo;

2 - Os resultados positivos, observados nas reações de ELISA, indicaram o contato da população humana com esporozoítos do "Complexo vivax" (Pvc, Pvk e Pvl), Pf e $\mathrm{Pm} / \mathrm{Pb}$;

3 - A positividade verificada com os peptídeos CS na população humana não se relacionou com a idade, sexo e tipo de ocupação. Contudo, a prevalência aumentou de acordo com o tempo de residência na área. A presença de indivíduos que moravam há pouco tempo na área e apresentaram resultados positivos, indicou contatos recentes com anofelinos infectados com esporozoítos de plasmódios humanos e/ou simianos;

4 - Os resultados positivos observados nas reações de IFI com o antígeno de $P$. vivax, sugeriram infecções antigas ou uma situação de assintomatologia na população humana. Os resultados negativos com o antígeno de $P$. falciparum indicaram a ausência de infecções por este plasmódio;

5 - Os resultados do exame parasitológico dos bugios (Alouatta caraya) capturados nos lados de São Paulo (SP) e Mato Grosso do Sul (MS), indicaram a presença de plasmódio semelhante ao $P$. vivax humano;

6- Os resultados positivos, nas reações de PCR, indicaram a presença de plasmódios semelhantes ao $P$. vivax e P.falciparum na população de bugios da área de estudo; 
7 - Os resultados positivos, observados nas reações de ELISA, indicaram o contato da população de bugios de SP e MS com esporozoítos do "Complexo vivax" (Pvc, Pvk e Pvl), Pf e Pm/Pb;

8 - A positividade verificada com os peptídeos CS na população de bugios de SP e MS não se relacionou com a idade e sexo;

9 - Os resultados positivos, observados nas reações de IFI, com o antígeno de $P$. vivax, $P$. malariae e $P$. falciparum sugeriram a ocorrência de infecções maláricas na população de bugios;

10 - A comparação dos resultados parasitológicos da população humana do Campinal (SP) e dos bugios capturados no lado de SP, sugere a presença de um quadro de transmissão na população de macacos $(P$. vivax, $P$. malariae e $P$. falciparum), que possivelmente envolve a população humana;

11 - A comparação dos resultados sorológicos indicou relação entre as respostas observadas em ambas as populações, sugerindo que, tanto a população humana quanto a simiana está exposta ao contato com anofelinos infectados com esporozoítos de $P$. vivax, $P$. malariae e $P$. falciparum. 


\section{REFERÊNCIAS}

Alencar FMA, Nogueira JCB, Emmerich W. A Lagoa São Paulo e alguns aspectos de sua fisiografia. São Paulo; Instituto Florestal; 1976 (Boletim Técnico, 20)

Alves FP, Durlacher RR, Menezes MJ, Krieger H, Pereira da Silva LH, Camargo EP. High prevalence of asymptomatic Plasmodium vivax and Plasmodium falciparum infections in native amazonian populations. Am J Trop Med Hyg 2002; 66: 641-8.

Arnot DE, Barnwell JW, Tam JP, Nussenzweig V, Nussenzweig RS Circumsporozoite protein of Plasmodium vivax gene cloning and characterization of the immunodominant epitope. Science $1985 ; 30: 815-8$.

Arruda ME. Presença do Plasmodium brasilianum em macacos capturados na área de enchimento do reservatório da Usina Hidroelétrica de Tucuruí, Pará. Mem Inst Oswaldo Cruz 1985; 80: 367-69.

Arruda ME, Nardin EH, Nussenzweig RS, Cochrane AH. Sero-epidemiological studies of malaria in indian tribes and monkeys of the Amazon Basin of Brazil. Am J Trop Med Hyg 1989; $41:$ 379-85.

Auricchio P. Primatas do Brasil. São Paulo, Terra Brasilis; 1995.

Baerg DC. A naturally acquired infection of Plasmodium brasilianum in the marmoset, Saguinus geoffroyi. Parasitol 1971; 57: 8.

Barata RB. Malária e seu controle. São Paulo, Hucitec; 1998. 
Barnwell JW. Antigens of Plasmodium vivax blood stage parasites identified by monoclonal antibodies. Mem Inst Oswaldo Cruz 1986; 81: 56-61.

Baxter RM. Environmental effects of dams and impoundments. Ann Rev Ecol Syst $1977 ; 8: 255-83$.

Berquó ES, Souza JMP, Gotlieb SLD. Bioestatística. $2^{a}$ ed. rev. São Paulo: EPU; 1981.

Blackman MJ, Heidrich HG, Donaiche S, McBride JS, Holder AA. A single fragment of malaria merozoite surface protein remains on the parasite during red cell invasion and is target of invasion inhibiting antibodies. J Exp Med 1990; 172: 379-382.

Bruce-Chwatt LJ. Essential malariology. London, William Heinemann Medical Books Ltd; $1985,2^{\mathrm{a}}$ edição.

Camargo LMA. A malária autóctone do litoral sul do Estado de São Paulo. São Paulo; 1992. [Dissertação de Mestrado, Escola Paulista de Medicina].

Canadian Council on Animal Care. Guide to the care and use of experimental animals. Ottawa; 1980-1984.

Cavasini MTV, Ribeiro WL, Kawamoto F, Ferreira MU. How prevalent is Plasmodium malariae in Rondônioa, Western Brazilian Amazon. Rev Soc Bras Med Trop 2000; 33: 489-92. 
Chin W, Contacos PG, Coatney, GR, Kimball HR. A naturally acquired quotidiantype malaria in man transferable to monkeys. Science 1965; 149: 865.

Clark HC. Progress in the survey for blood parasites of the wild monkeys of Panamá. Am J Trop Med Hyg 1931; 11: 11-20.

Coatney GR. The simian malarias: zoonoses, anthroponoses, or both? Am J Trop Med Hyg 1971; 20: 795-803.

Cochrane AH, Aikawa $M$, Jeng $M$, Nussenzweig RS. Antibody-induced ultrastructural changes of malarial sporozoites. J Immunol 1976; 116: 859-67.

Cochrane AH, Collins WE, Nussenzweig RS. Monoclonal antibody identifies circumsporozoite protein of Plasmodium malariae and detects a common epitope on Plasmodium brasilianum sporozoites. Infect Immun 1984; 45: 592-5.

Cochrane AH, Barnwell JW, Collins WE, Nussesweig RS. Monoclonal antibodies produced against sporozoites of the human parasite Plasmodium malariae abolish infectivity of sporozoites of the simian parasite Plasmodium brasilianum. Infect Immun, 1985; 50:58-61.

Cochrane AH, Nardin EH, Arruda M, Maracic M, Clavijo P, Collins WE, Nussenzweig RS. Widespread reactivity of human sera with a variant repeat of the circumsporozoite protein of Plasmodium vivax. Am J Trop Med Hyg 1990; 43: 446-51. 
Collins WE, Jeffery GM, Guinn E, Skinner JC. Fluorescent antibody studies in human malaria. IV. Cross-reactions between human and simian malaria. Am J Trop Med Hyg 1966; 15: 11-5.

Collins WE. Major animal models in malaria research: simian. In: Wernsdofer WH, McGregor I, editors. Malaria: principles and practices of malariology. Edinburgh: Churchill Livingstone; 1988.

Consolim J, Luz E, Pellegrini NJM, Torres PB. O Anopheles (Nyssorhynchus) darlingi Root, 1926 e a malária no lago de Itaipu, Estado do Paraná, Brasil. Uma revisão de dados (Díptera, Culicidae). Arq Biol Technol 1991; 34:263-86.

Contacos PG, Lunn JS, Coatney GR, Kilpatrick JW, Jones FE. Quartan-type malaria parasite of New World monkeys transmissible to man. Science 1963; 142: 676.

Coosemans M., Mouchet J. Consequences of rural development on vectors and their control. Ann Soc Belge Med Trop 1990; 70: 5-23.

Curado I. Soroepidemiologia de malária em áreas de baixa endemicidade no Estado de São Paulo. São Paulo; 1995. [Dissertação de Mestrado, Instituto de Ciências Biomédicas, USP].

Curado I, Duarte AMRC, Lal AA, Oliveira SG, Kloetzel JK. Antibodies antibloodstream and circumsporozoite antigens (Plasmodium vivax and Plasmodium malariae/P.brasilianum) in areas of very low malaria endemicity in Brazil. Mem Inst Oswaldo Cruz 1997; 92: 235-43. 
Curado I. Estudo epidemiológico sobre a malária humana e simiana e infeç̧ão de anofelinos em áreas de baixa endemicidade no Estado de São Paulo. São Paulo; 2003. [Dissertação de Doutorado, Faculdade de Saúde Pública, USP, USP].

Dame JB, Williams JL, McCutchan TF, Weber J, Hockmeyer WT, Maloy WL, Haynes JD, Schneider I, Roberts D. Structure of the gene encoding the immunodominant surface antigen on the sporozoite of the human malaria parasite Plasmodium falciparum. Science 1984; 225: 593-99.

Deane LM. Studies on simian malaria in Brazil. Bull World Health Organ 1964; 31 : 752-3.

Deane LM, Deane MP, Ferreira Neto JA. Studies on transmission of simian malaria and on a natural infection of man with Plasmodium simium in Brazil. Bull World Health Organ 1966; 35: 805-8.

Deane LM, Ferreira Neto JA, Sitônio JG. Novo hospedeiro natural do Plasmodium simium e do Plasmodium brasilianum: O mono, Brachyteles arachnoides. Rev Inst Med Trop São Paulo 1968; 10: 287-8.

Deane LM. Plasmodia of monkeys and malaria eradication in Brazil. Rev Lat Am Microbiol Parasitol 1969a; 11: 69-73.

Deane LM, Ferreira Neto JA. Malária em macacos do Estado do Rio Grande do Sul. Observações preliminares. Rev Inst Med Trop São Paulo 1969b; 11: 299-305. 
Deane LM, Ferreira Neto JA, Okumura M, Ferreira MO. Malaria Parasites of Brazilians Monkeys. Rev Inst Med Trop São Paulo 1969c; 11: 71-86.

Deane LM, Ferreira Neto JA, Deane MP, Silveira IPS. Anopheles (Kerteszia) cruzii, a natural vector of the monkey malaria parasites, Plasmodium simium and Plasmodium brasilianum. Trans R Soc Trop Med Hyg 1970; 64: 647.

Deane LM, Deane MP, Ferreira Neto JA, Almeida FB. On the transmission of simian malaria in Brazil. Rev Inst Med Trop São Paulo 1971; 13: 311-9.

Deane LM, Ferreira Neto JA. Malária de macacos no Estado de Goiás, Brasil: Encontro de Guaribas, Alouatta caraya, infectados com Plasmodium brasilianum. Rev Inst Med Trop São Paulo 1973; 15: 107-11.

Deane LM. Epidemiology of simian malaria in the American Continent. Washington (DC): PAHO; 1976,. p. 144-163 (PAHO-Scientific Publication, 317).

Deane LM, Lourenço-de-Oliveira R, Ziccardi M, Luz SLB. Simian plasmodia and trypanosomes in Rondônia State, Brazil. Mem Inst Oswaldo Cruz 1989; 84 Supl 2: 143.

Deane LM. Simian malaria in Brazil. Mem Inst Oswaldo Cruz 1992; 87 Supl 3: 120. 
Dégallier N, Da Rosa PAT, Vasconcelos PFC, Hervé JP, Sá Filho GC, Da Rosa JFST, Da Rosa EST, Rodrigues SG. Modifications of arbovirus transmission in relation to construction of dams in Brazilian Amazônia. Cienc e Cult 1990; 44:12435.

Duarte, AMRC. Estudo de malária em macacos silvestres brasileiros. São Paulo; 1998. [Dissertação de Mestrado, Instituto de Ciências Biomédicas, USP].

Dunn FL, Lambrecht FL. The host of Plasmodium brasilianum Gonder e Von Berenberg-Gossler. J Parasitol 1963; 49: 316-19.

Emin A. Une variete nouvelle du parasite de Laveran. Bull Soc Pathol Exot 1914; 7: 385-7.

Enea V, Arnot D, Schimidt EC, Cochrane A, Gwadz R, Nussenzweig RS. Circumsporozoite gene of Plasmodium cynomolgi: cDNA cloning and expression of the repetitive circumsporozoite epitope. Proc Natl Acad Sci 1984; 81: 7520-24.

Escalante A, Ayala FJ. Phylogeny of the malarial genus Plasmodium derived from rRNA gene sequences. Proc Natl Acad Sci 1994; $11373-7$.

Escalante AA, Barrio E, Ayala F. Evolutionary origin of human and primate malarias: Evidence from the circumsporozoite protein gene. Mol Biol Evol 1995; 12: 616-26.

Fandeur T, Volney B, Peneau C, De Thoisy B. Monkeys of the rainforest in French 
Guiana are natural reservoirs for $P$. brasilianum/P. malariae. Parasitol 2000; 120: 11-21.

Ferreira AW, Sanchez MC. Malária humana: padronização e optimização de testes sorológicos para diagnóstico individual e inquéritos soroepidemiológicos. Rev Inst Med Trop São Paulo 1988; 30: 137-46.

Fidock DA, Sallenave-Sales S, Sherwood JA, Gachihi GS, De Fatima Ferreira-daCruz M, Thomas AW, Druilhe P. Conservation of the Plasmodium falciparum sporozoite surface protein gene, STARP, in field isolates and distinct species of Plasmodium. Mol Biochem Parasitol 1994; 67: 255-67.

Fonseca F. Plasmódio de Primata do Brasil. Mem Inst Oswaldo Cruz 1951; 49: 54351.

Fundação IBGE. Sinopse Preliminar do Censo Demográfico:1991. São Paulo; 1991.

Fundação IBGE. População residente, por situação do domicílio e sexo, segundo as Mesoregiões, as Microregiões, os Municípios, os Distritos e os Bairros - Estado de São Paulo [on line] $2003 \quad$ Abr 30. URL:htpp://www.ibge.gov.br/home/estatistica/população/censo2000/tabelas grandesregiões 211.shtm.

Fundação IBGE. Anuário estatístico do Brasil: 1997. Rio de Janeiro; 1998; v.57. 
[FUNASA] Fundação Nacional da Saúde. Malária (todas as formas). Lâminas positivas, por unidade federada. Brasil, 1980-2001 [on line] 2002 Nov 17. URL:htpp://www.funasa.gov.br/epi/pdfs/casos_conf_por_UF_1980_2001.pdf $>$.

Goldman IF, Qari SH, Millet PG, Collins WE, Lal AA. Circumsporozoite protein gene of Plasmodium simium, a Plasmodium vivax-like monkey malaria parasite. Mol Biochem Parasitol 1993; 57: 177-80.

Gonder R, Berenberg-Gossler H. Untersuschungen über die Malariaplasmodien der Affen. Malaria Lpz 1908; 1: 47-56.

Goodland R. Environmental assentament of the Tucurui hydroproject, rio Tocantis, Amazonia, Brazil. Brasilia, DF. Eletronorte AA; 1978.

Gozalo A, Lucas C, Cachay M, Montoya E, Ballou WR, Wooster T, Watts DM. Prevalence of antibody to $P$. falciparum antigens among feral Saimiri monkeys in the Amazon basin region of Peru. J Med Primatol 1997; 26: 204-06.

Hunter JM, Hay L, Scott D. Man-made lakes and man made diseases towards a policy resolution. Soc Sci Med 1982; 16: 1127-45.

Junk WJ, Nunes de Mello JAS. Impactos ecológicos das represas hidrelétricas na bacia amazônica brasileira. Estud Avanç 1990; 4:126-143.

Kain KC, Keystone J, Franke ED, Lanar DE. Global distribution of a variant of the circumsporozoite gene of Plasmodium vivax. J Infect Dis 1991; 164: 208-10. 
Kawamoto F, Win TT, Mizuno S, Lin K, Kyaw O, Tantular I, Mason DP, Kimura M, Wongsrichanalai C. Unsual Plasmodium malariae-like parasites in Southeast Asia. J Parasitol 2002; 88: 350-7.

Kemp DJ, Coppel RL, Anders RF. Repetitive proteins and genes of malaria. Annu Rev Microbiol 1987; 41: 181-208.

Kimura M, Kaneto O, Liu Q, Zhou M, Kawamoto F, Wataya Y, Otani S, Yamaguchi $\mathrm{Y}$, Tanabe K. Identification of the four species of human malaria parasites by nested PCR that targets variant sequences in the small subunit rRNA gene. Parasitol Int 1997; 46: 91-5.

Knowles R, Das Gupta BM. A study of monkey malaria and its experimental transmission to man. Indian Med Gaz 1932; 67: 301-20.

Kremsner PG, Neifer S, Zotter GM, Bienzle U, Rocha RM, Maracic M, Clavijo P, Nussenzweig RS, Cochrane AH. Prevalence and level of antibodies to the cirumsporozoite proteins of human malaria parasites, including a variant of Plasmodium vivax, in the population of two epidemiologically distinct areas in the state of Acre, Brazil. Trans R Soc Trop Med Hyg 1992; 86:23-7.

Lal AA, De la Cruz VF, Campbell GH, Procell PM, Collins WE, McCutchan TF. Structure of the circumsporozoite gene of Plasmodium malariae. Mol Biochem Parasitol 1988a; 30: 291-4.

Lal AA, De La Cruz VF, Collins WE, Campbell GH, Procell PM, McCutchan TF. Circumsporozoite protein gene from Plasmodium brasilianum. Animal reservoirs for human malaria parasites? J Biol Chem 1988b; 263: 5495-8. 
Lal AA, Goldman IF. Circumsporozoite protein gene from Plasmodium reichenowi, a chimpanzee malaria parasite evolutionary related to the human malaria parasite Plasmodium falciparum. J Biol Chem 1991; 266: 6686-9.

Li J, Collins WE, Wirtz RA, Rathore D, Lal A, McCutchan TF. Geografic subdivision of the range of the malaria parasite Plasmodium vivax. Emerg Infect Dis 2001; 7: 35-42.

Lim CS, Kim YK, Lee KN, Hoffiman KJ, Song KJ, Song JW. The analysis of circumsporozoite-protein gene sequences from South Korean isolates of Plasmodium vivax. Ann Trop Med Parasitol 2001; 95: 229-35.

Lockyer MJ, Schwarz RT. Strain variation in the circumsporozoite protein gene of Plasmodium falciparum. Mol Biochem Parasitol 1987; 22: 101-08.

López Antuñano FJ, Schumis G, editores. Diagnóstico de malária. Whashington (DC): OPAS; 1988. (OPAS - Publicação Científica, 512).

Lourenço-de-Oliveira R. Hemoparasitos encontrados em alguns mamíferos de Balbina Estado do Amazonas. Mem Inst Oswaldo Cruz 1988; 83 Supl 1: 233.

Lourenço-de-Oliveira R. Natural infection of golden lion tamarin, Leontopithecus rosalia, with Trypanosoma cruzi, in the state of Rio de Janeiro, Brazil. Mem Inst Oswaldo Cruz 1990; 85 Supl 1: 15.

Lourenço-de-Oliveira R, Deane LM. Simian malaria at two sites in the Brazilian Amazon. I - The infection rates of Plasmodium brasilianum in non-human primates. Mem Inst Oswaldo Cruz 1995; 90: 331-9. 
Machado RL, Povoa MM. Distribution of Plasmodium vivax variants (VK210, VK247, $P$. vivax-like) in the three endemic areas of the Amazon region of Brazil and their correlation with chloroquine treatment. Trans R Soc Trop Med Hyg 2000, 94: 377-81.

Marinkelle CJ, Grose ES. Plasmodium brasilianum in colombian monkeys. Trop Geogr Med 1968; 20: 276-80.

Mann VH, Huang T, Cheng Q, Saul A. Sequence variation in the circumsporozoite protein gene of Plasmodium vivax appers to be regionally biased. Mol Biochem Parasitol 1994; 68: 45-52.

Mann VH, Good MF, Saul A. Diversity in the circumsporozoite protein of Plasmodium vivax: does is matter? Parasitol Today 1995; 11:33-6.

Marrelli MT, Branquinho MS, Hoffmann EHE, Benevento CM, Natal D, Taipe-Lagos CB, Kloetzel JK. ELISA with Plasmodium vivax-like/P.simiovale CS repeats in human sera and in anophelines from the State of Acre, Brazil. Mem Inst Oswaldo Cruz 1997; 92 Supl 1: 268.

McCutchan TF, Lal AA, Cruz VF, Miller LH, Maloy WL, Charoenvit Y, Beaudoin RL, Guerry P, Wistar R, Hoffman SL, Hockmeyer WT, Collins WE; Wirth D. Sequence of the immunodominant epitope for the surface protein on sporozoites of Plasmodium vivax. Science 1985; 230: 1381-3.

Ménard R. The journey of the malaria sporozoite through its hosts: two parasites proteins lead the way. Microbes Infect 2000; 2: 633-42. 
Menezes RMT. Composição e atividade de mosquitos (Diptera, Culicidae) da área de influência indireta das Hidrelétricas de Canoas I e II. Bacia do Rio Paranapanema, de 1993 a 1995. São Paulo; 1997 [Dissertação de Mestrado, Faculdade de Saúde Pública, USP].

Most H. Plasmodium cynomolgi malaria: accidental human infection. Am J Trop Med Hyg 1973; $22:$ 157-8.

Mucci LF. Modelagem espacial do risco epidemiológico para malária em porção paulista da zona de influência do Reservatório de Porto Primavera. São Paulo; 1999 [Dissertação de Mestrado, Instituto de Biociências, USP].

Müller AC, Hidrelétricas, meio ambiente e desenvolvimento. São Paulo: Makron Books; 1995.

Natal D, Barata EAMF, Urbinatti PR, Barata JMS. Sobre a fauna de mosquitos adultos (Díptera: Culicidae) em área de implantação de hidrelétrica na bacia do Rio Paraná, Brasil. Rev Bras Entomol 1998; 1: 213-16.

Natal D. Efeitos da inundação sobre culicídeos, com ênfase na população de Aedes scapularis (Rondani, 1848), da área de influência da Hidrelétrica de Porto Primavera, São Paulo, 2001 [Dissertação de Livre Docência, Faculdade de Saúde Pública, USP]. 
Nussenzweig RS, Nussenzweig V. Development of sporozoite vaccines. Philos Trans R Soc Lond (Biol) 1984; 307: 117.

Nussenzweig RS, Montuori W, Spitalny GL, Ghen D. Antibodies against sporozoites of human and simian malaria produced in rats. J Immunol 1973; 110: 600-01.

Oliveira DA, Holloway BP, Durigon EL, Collins WE, Lal AA. Polymerase chain reaction and a liquid-phase, nonisotopic hybridization for species-specific and sensitive detection of malaria infection. Am J Trop Med Hyg 1995a; 52: 139-44.

Oliveira DA, Qari S, Machado RLD, Oliveira S, Povoa MM, Collins W, Lal AA. Prevalence of P.vivax-like malaria parasite in a malaria endemic region of Brazil. In: Caderno de resumos do $14^{\circ}$ Congresso Brasileiro de Parasitologia; 1995b. Ago 14; Goiânia., p.236.

Ollomo B, Karch S, Buerau P, Elissa N, Georges AJ, Millet P. Lack of malaria parasite transmission between apes and humans in Gabon. Am J Trop Med Hyg 1997; 56: 440-5.

[PAHO] Pan American Health Organization. Status of malaria in the Americas. Washington (DC); 1998. (PAHO/HCP/HCT/98).

Paula MB. Fauna de culicídeos (Díptera: Culicidae) em área sob influência do Lago Porto Primavera; Município de Presidente Epitácio, São Paulo, Brasil. São Paulo; 2001.[Dissertação de Mestrado, Faculdade de Saúde Pública, USP]. 
Philpott J, Keystone JS, Reid A, Chulay JD, Wirtz RA, Szarfman A. Effect of malaria chemoprophylaxix on the development of antibodies to Plasmodium falciparum in expatriates living in west Africa. Am J Trop Med Hyg 1990; 42: 28-45.

Porter JA, Johnson CM, Souza L. Prevalence of malaria in Panamanian primates. J Parasitol 1966; 52: 669-70.

Qari SH, Goldman IF, Povoa MM, Oliveira S, Alpers MP, Lal AA. Wide distribution of the variant form of the human malaria parasite Plasmodium vivax. J Biol Chem 1991; 266: 297-300.

Qari SH, Goldman IF, Povoa MM, Olivers S, Alpers MP, Lal AA. Polymorphism in the circumsporozoite protein of the human malaria parasite Plasmodium vivax. Mol Biochem Parasitol 1992; 55:105-14.

Qari SH, Shi Y, Goldman IF, Udhayakumar V, Alpers MP, Collins WE, Lal AA. Identification of Plasmodium vivax-like human malaria parasite. Lancet 1993; 341: 780-3.

Ranjit MR, Sharma YD. Genetic polymorphism of falciparum malaria vaccine candidate antigen genes among field isolates in India. Am J Trop Med Hyg 1999; 61: 103-8.

Rey L. Parasitologia. $2^{\mathrm{a}}$ ed. Rio de Janeiro, Guanabara Koogan; 1991.

Robson KJ, Hall JR, Jennings MW, Harris TJ, Marsh K, Newbold CI, Tate VE, Weathreall DJ. A highly conserved amino-acid sequence in thrombospondin, 
properdin, and in proteins from sporozoites and blood stages of human malaria parasite. Nature 1988; 335: 79-82.

Rodhaini J. Les Plasmodiums des anthropoides de l'Afrique Centrale et leurs relations avec les Plasmodiums humains. Receptivite lhomme au Plasmodium malariae (Plasmodium rodhaini, Brumpt) du chimpanzee. C R Seances Soc Biol Fil 1940; 133: 276-7.

Rosenberg R, Wirtz RA, Lanar DE, Sattabongkot J, Hall T, Waters AP, Prasittisuk C. Circumsporozoite protein heterogeneity in the human malaria parasite Plasmodium vivax. Science 1989; 245: 973-6.

Roudy RW. Problems of resettlement and vector-borne diseases associated with dams and other development schemes. In: Service, MW. Demography and vector-borne diseases. Boca Raton, CRC Press; 1989, p. 194-223.

Sambrook J, Fritsch EF, Maniatis T. Molecular cloning: a laboratory manual. Cold Spring Harbor Laboratory, 1989.

Santos AH, Abraão N, Camargo MF, Oliveira AWS, Alves RBN, Isaac E. Prevention and control of the malaria disease in the area of Serra da Mesa Hydrelectric Plant in Goiás. Mem Inst Oswaldo Cruz 1997; 92 Supl 1: 307.

Seed TM, Sterling CR, Aikawa M, Rabbege J. Plasmodium simium: Ultrastructure of erythrocitic phase. Exp Parasitol 1976; 39: 262-76. 
Serrano JA. Infección natural de um araguato Alouatta seniculus straminea, por Plasmodium brasilianum en Venezuela. Acta Cient Venez 1967; 18: 13-5.

Snounou G, Viriyakosol S, Zhu XP, Jarra W, Pinheiro L, Do Rosario VE, Thaithong $\mathrm{S}$, Brown $\mathrm{KN}$. High sensitivity of detection of human malaria parasites by use the nested polymerase chain reaction. Mol and Biochem Parasitol 1993; 61: 315-20.

Stata Corp. Stata Statistical Software: release 7.0. College Station, TX: Stata Corporation 2001.

Stephens JWW. A new malaria parasite of man. Proc R Soc Lond 1914; 87: 375-7.

[SUCEN] Superintendência de Controle de Endemias - Avaliação do Programa de Controle de Malária. Estado de São Paulo - período de 1992 a 1994. São Paulo; 1995.

[SUCEN] Superintendência de Controle de Endemias. Casos autóctones de malária, por ano e local provável de infecção, região do Planalto Ocidental, 1990 a 2000 [on line], 2002 Nov 20 URL://www.sucen.sp.gov.br/basededados/Tab mal/texto tab mal lam1.htm.

Tadei WP, Mascarenhas BM, Podesta MG. Biologia de anofelinos amazônicos. VIII. Conhecimentos sobre a distribuição de espécies Anopheles na região de Tucuruí Marabá (Pará). Acta Amazon 1983; 13: 103-40.

Tadei WP, Thatcher BD, Santos JMM, Costa WL, Scarpassa VM, Rodrigues IB, Rafael MS. Ecologic observations on anopheline vectors of malaria in the Brazilian Amazon. Am J Trop Hyg Med 1998; 59:325-35. 
Taliaferro WH. Experimental studies on the malaria monkeys. Am J Hyg 1932; 16: $429-49$.

Tauil PL. Estudo de alguns aspectos da epidemiologia da malária em Porto

Nacional, Estado de Goiás, Brasil. São Paulo, 1980 [Dissertação de mestrado, Faculdade de Medicina, USP].

Teodoro U, Guilherme ALF, Lozovei AL, Filho VLA, Fukushigue Y, Spinosa RP, Ferreira MEMC, Barbosa OC, Lima EM. Culicídeos do lago de Itaipu, no Rio Paraná, Sul do Brasil. Rev Saúde Pública 1995; 29: 6-14.

Thomas V, Fabiyi A, Adenyi A. Prevalence of antibodies to parasitic infections in Nigerian children. Am J Trop Med Hyg 1981; 84: 113-6.

Tobie JE, Coatney GR. Fluorescent antibody staining of human malaria parasite. Exp Parasitol 1961; 11: 128-32.

Tobie JE, Kuvin SF, Contacos PG, Coatney GR, Evans CB. Fluorescent antibody studies on cross reaction between human and simian malaria in normal volunteers. Am J Trop Med Hyg 1962; 11: 586-96.

Van Thiel PH. Malaria problems arising from the construction of a reservoir in the interior of Surinam. Trop Geogr Med 1962; 14: 259-78.

Vanderberg JP, Nussenzweig RS, Most H. Protective immunity by the injection of Xirradiated sporozoites of Plasmodium berghei: in vitro effects of immune serum on sporozoites. Mil Med 1969; 134: 1183-90. 
Volney B, Pouliquen JF, De Thoisy B, Fandeur T. A sero-epidemiological study of malaria in human and monkey population in French Guiana. Acta Trop 2002; 82: 1123.

Warhurst DC, Tucker JM, Póvoa MM, Green PJ. Unusual Plasmodium related to $P$. simiovale. Lancet 1993; 341:1408.

Warren $\mathrm{McW}$. Simian malaria and anthropoid malarias - their role in human disease. Lab Anim Care 1970; 20: 368-76.

Waters AP, Higgins DG, McCutchan TF. The phylogeny of malaria: A useful study. Parasitol Today 1993; 9: 246-50.

Wijesundera MS. Malaria outbreaks in new foci in Sri Lanka. Parasitol Today 1988; 4: $147-50$.

[WHO] World Health Organization. Procedimentos laboratoriais em parasitologia médica. $2^{a}$ ed. São Paulo: Livraria Santos; 1999.

[WHO] World Health Organization. World malaria situation in 1993. Wkly Epidemiol Rec 1996b; 71:25-32.

Zavala F, Tam JP, Masuda A. Synthetic peptides as antigens for the detection of humoral immunity to Plasmodium falciparum sporozoites. J Immunol Meth 1986; 93: 55-61. 
Faculdade de Saúde Pública USP - Dept. Epidemiologia

Projeto: Investigação de Malária na Barragem de Porto Primavera

$\mathrm{N}^{\mathrm{o}}:$ Data: Local: GPS:

Nome:

Idade:

Sexo: $F(\quad) \quad M(\quad)$

Grau de Parentesco: ( ) Permanente ( ) Visitante

Naturalidade:

Profissão:

Endereço: $\mathrm{n}^{0}$

Reside a quanto tempo no local: (anos) (meses)

Residências anteriores (Local/Cidade/Estado):

Atividades desenvolvidas (trabalho e lazer /caça e pesca) (Onde?):

Deslocamento e Viagens para outras áreas (Cidade/Estado/mês/ano/ tempo de permanência)

Presença de Permilongos: ( ) Domicílio （ ) Peri-domicílio （ ) Não acusa Abundância ( ) Muitos ( ) Poucos

Em que época do ano: Em que horário:

Mora próximo de coleções de águas: ( ) Sim ( ) Não / Distância____ Km Mora próximo de matas: ( ) Sim ( ) Não Distância___ $\mathrm{Km}$
Vê macacos?:
( ) $\operatorname{Sim}$ ( ) Não 
Recentemente teve: Calafrio, febre, sudorese, dor de cabeça, dor no corpo/ abdominal, náuseas, vômitos.

( ) $\operatorname{Sim}$ ( ) Não (riscar o indicado)

Já teve malária? ( ) Sim ( ) Não Quando/Onde?

Qual plasmódio e local de tratamento

Conhece alguém da região que esteve ou está com malária?:( ) Sim （ ) Não Quem?

Onde?: Quando?:

Esteve doente nos últimos 6 meses? ( ) Sim （）Não

Qual doença e tratamento:

Toma algum remédio atualmente:( ) Sim ( ) Não Qual?

Doou ou recebeu sangue nos últimos 6 meses : ( ) Sim （）Não Onde?: Quando?:

\section{SANGUE COLHIDO : ( ) SIM （） NÃO}

Obs:

Resultados: Gota espessa/Esfregaço:

PCR

Sorologia: IFI

ELISA 


\section{TERMO DE CONSENTIMENTO}

Trabalhamos na Faculdade de Saúde Pública da Universidade de São Paulo e estamos fazendo um estudo aqui na região para saber se existem muitos casos de malária. Esta doença é muito séria e precisa ser tratada. É transmitida por mosquito que pode se criar nas lagoas e margens da Barragem de Porto Primavera.

Para melhor atendimento de saúde da comunidade, sua colaboração é muito importante. Precisamos que as pessoas que moram aqui permitam que retiremos uma pequena amostra de sangue para exame e verificar se existem pessoas doentes e também saber quando poderemos evitar que a doença se espalhe para outras pessoas da familia ou vizinhos.

Quando encontrarmos alguma pessoa doente, nós informaremos ao serviço de saúde responsável. Nós nos comprometemos a manter sigilo sobre o nome dos doadores e seus resultados.

\section{De acordo,}

Assinatura:

Nome do Doador:

Local:

Data: 1

Para qualquer informação necessária sobre a malária e este estudo, estamos na Faculdade de Saúde Pública/USP - Departamento de Epidemiologia, em São Paulo no endereço:

Av. Dr. Arnaldo, 715 - Cep. 01246-904 - Telefone: (11) 3081- 2108, falar com os responsáveis pela pesquisa: Professor Almério de Castro Gomes e Ana Maria R. C. Duarte.

(Termo feito em 2 vias: 1 para o pesquisador ; 1 para o doador) 


\section{UNIVERSIDADE DE SĀO PAULO FACULDADE DE SAUUDE PÜBLICA \\ COMITÉ DE ÉTICA EM PESQUISA-COEP}

Av. Dr. Arnaldo, 715 - Cerqueira César

São Paulo-SP - CEP: 01246-904

Telefone: (Oxx11) 3066-7779 - e-mail: mdgracas@usp.br

\section{Of.COEP/176/01}

31 de agosto de 2001

Pelo presente, informo que o Comitê de Ética em Pesquisa da Faculdade de Saúde Pública da Universidade de São Paulo-COEP, analisou e aprovou em 25.06.99, de acordo com os requisitos da Resolução CNS/196/96, o Protocolo de Pesquisa, intitulado: "ESTUDO EPIDEMIOLÓGICO SOBRE A MALÁRIA HUMANA E SIMIANA EM ÁREA DE INFLUÊNCIA DA BARRAGEM DE PORTO PRIMAVERA E SUA RELAÇÃO COM NOVOS FATORES DE TRANSMISSÃO”, apresentado pelo Coordenador Almério de Castro Gomes e da pesquisadora Ana Maria Ribeiro de Castro Duarte

Atenciosamente,

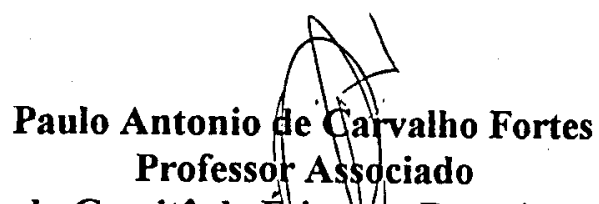

Coordenador do Comitê de Ética em Pesquisa da FSP-COEP 


\section{Promega}

\section{TECHNI CAL MANUAL}

\section{Wizard ${ }^{\circledR}$ Genomic DNA Purification Kit}




\section{Wizard ${ }^{\circledR}$ Genomic DNA Purification Kit}

Technical Manual No. 050

WSTRUCTIONS FOR USE OF PRODUCTS A1120, A1123, A1125 AND A1620.

PLEASE DISCARD PREVOUS VERSIONS.

All Technical Literature is Avallable on the Internet at www.promega.com

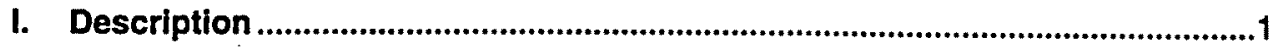

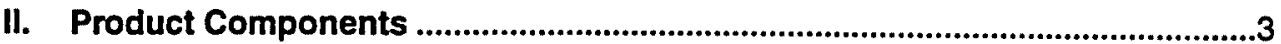

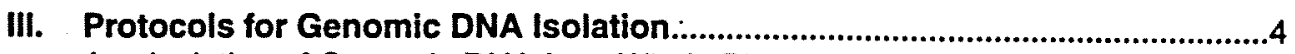

A. Isolation of Genomic DNA from Whole Blood

(300 1 l or $3 \mathrm{ml}$ Sample Volume) ..........................................................................4

B. Isolation of Genomic DNA from Whole Blood

(10ml Sample Volume)

C. Isolation of Genomic DNA from Whole Blood

(96 Well Plate)

D. Isolation of Genomic DNA from Tissue Culture Cells and Animal Tissue

E. Isolation of Genomic DNA from Plant Tissue ..............................................11

F. Isolation of Genomic DNA from Yeast...........................................................12

G. Isolation of Genomic DNA from Gram Positive and

Gram Negative Bacteria ................................................................................13

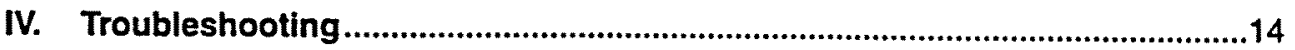

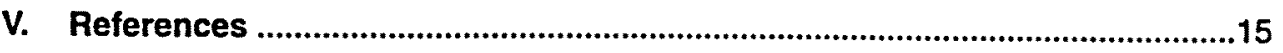

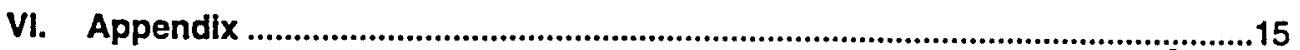

A. Composition of Buffers and Solutions ........................................................15

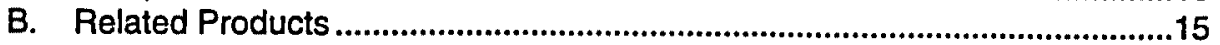

I. Description

The Wizard ${ }^{\circledR}$ Genomic DNA Purification Kit is designed for isolation of DNA from white blood cells (Sections III.A, B and C), tissue culture cells and animal tissue (Section III.D), plant tissue (Section III.E), yeast (Section III.F), Gram positive and Gram negative bacteria (Section III.G). Table 1 lists the typical yield for DNA purified from each of these sources.

The Wizard Genomic DNA Purification Kit is based on a four-step process (1). The first step in the purification procedure lyses the cells and the nuclei. For isolation of DNA from white blood cells, this step involves lysis of the red blood cells in the Cell Lysis Solution, followed by lysis of the white blood cells and their nuclei in the Nuclei Lysis Solution. An RNase digestion step may be included at this time; it is optional for some applications. The cellular proteins are then removed by a salt precipitation step, which precipitates the proteins but leaves the high molecular weight genomic DNA in solution. Finally, the genomic DNA is concentrated and desalted by isopropanol precipitation.

DNA purified with this system is suitable for a variety of applications, including amplifications, digestion with restriction endonucleases and membrane hybridizations (e.g., Southern and dot/slot blots).

Promega Corporation - 2800 Woods Hollow Road · Madison, WI 53711-5399 USA - Toll Free in USA 800-356-9526 - Telephone 608-274-4330 - Fax 608-277-2516 - www.promega.com 


\section{Promega}

-Process as little as $20 \mu l$ per well; see Table 2.
Table 1. DNA Yields from Various Starting Materials.

\begin{tabular}{|c|c|c|c|}
\hline Species and Material & $\begin{array}{l}\text { Amount of } \\
\text { Starting Material }\end{array}$ & $\begin{array}{l}\text { Typical } \\
\text { DNA Yield }\end{array}$ & $\begin{array}{l}\text { RNase } \\
\text { Treatment }\end{array}$ \\
\hline $\begin{array}{l}\text { Human Whole Blood } \\
\text { (Yield depends on the } \\
\text { quantity of white blood } \\
\text { cells present.) } \\
96 \text { well plate* }\end{array}$ & $\begin{array}{l}300 \mu \mathrm{l} \\
1.0 \mathrm{ml} \\
10.0 \mathrm{ml} \\
50 \mu \mathrm{l} / \mathrm{well}\end{array}$ & $\begin{array}{l}5-15 \mu \mathrm{g} \\
25-50 \mu \mathrm{g} \\
250-500 \mu \mathrm{g} \\
0.2-0.7 \mu \mathrm{g}\end{array}$ & $\begin{array}{l}\text { Optional } \\
\text { Optional } \\
\text { Optional } \\
\text { Optional }\end{array}$ \\
\hline
\end{tabular}

Mouse Whole Blood EDTA (4\%) treated Heparin (4\%) treated 96 well plate

$\begin{array}{lll}300 \mu l & 6 \mu g & \text { Optional } \\ 300 \mu l & 6-7 \mu g & \text { Optional } \\ 50 \mu 1 / \text { well } & 0.2-0.7 \mu g & \text { Optional }\end{array}$

Cell Lines

K562 (human)

cos (African green monkey)

NIH3T3 (mouse)

PC12 (rat pheochromocytoma)

$\mathrm{CHO}$ (Chinese hamster ovary)

$3^{\sim} 10^{6}$ cells

15-30нg

Required

$1.5^{-10^{6}}$ cells

$10 \mu \mathrm{g}$

Required

$2.25{ }^{\circ} 10^{6}$ cells

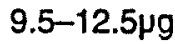

Required

$8.25{ }^{`} 10^{6}$ cells

$6 \mu g$

Required

$1-2 ` 10^{-6}$ cells

$6-7 \mu \mathrm{g}$

Required

Animal Tissue

Mouse Liver

$11 \mathrm{mg}$

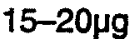

Required

Mouse Tail

$0.5-1 \mathrm{~cm}$ of tail

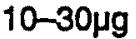

Optional

Insects

Sf9 Cells

$5^{-106}$ cells

$16 \mu g$

Required

Plant Tissue

Tomato Leaf

$40 \mathrm{mg}$

$7-12 \mu \mathrm{g}$

Required

Gram Negative Bacteria

Escherichia coli JM109, overnight culture, 2 ${ }^{-} 10^{9} \mathrm{cells} / \mathrm{ml} \mathrm{mml}$

$5 \mathrm{ml}$

$20 \mu g$ Required

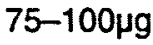
Required

Enterobacter cloacae, overnight culture, $\sim 6^{-} 10^{9} \mathrm{cells} / \mathrm{ml} \mathrm{ml}$

$20 \mu \mathrm{g}$ Required

$5 \mathrm{ml}$

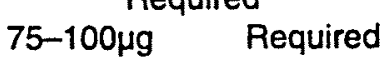

$6-13 \mu \mathrm{g}$ Required

Yeast

Saccharomyces cerevisiae, overnight culture, $\sim 1.9^{-} 10^{8} \mathrm{cells} / \mathrm{ml} \quad 1 \mathrm{ml}$ 4.5-6.5ug Required 


\section{Promega}

\section{Product Components}

\section{Small-Scale Isolation (miniprep)}

Product Size Cat.\#

Wizard ${ }^{8}$ Genomic DNA Purification Kit 100 isolations A1120

Each system contains sufficient reagents for 100 isolations of genomic DNA from $300 \mu$ l of whole blood samples. Includes:

- $100 \mathrm{ml}$ Cell Lysis Solution

- $\quad 50 \mathrm{ml}$ Nuclei Lysis Solution

- $25 \mathrm{ml}$ Protein Precipitation Solution

- $50 \mathrm{ml}$ DNA Rehydration Solution

- $250 \mu$ RNase Solution

1 Protocol

Product Size Cat.\# Wizard Genomic DNA Purification Kit 500 isolations A1125

Each system contains sufficient reagents for 500 isolations of genomic DNA from $300 \mu$ l of whole blood samples. Includes:

- $500 \mathrm{ml}$ Cell Lysis Solution

- $250 \mathrm{ml}$ Nuclei Lysis Solution

- $125 \mathrm{ml}$ Protein Precipitation Solution

- $100 \mathrm{ml}$ DNA Rehydration Solution

- $1.25 \mathrm{ml}$ RNase Solution

- 1 Protocol

\section{Large-Scale Isolation (maxiprep)}

Product

Wizard Genomic DNA Purification Kit Size

Each system contains sufficient reagents for 100 isolations of genomic DNA from $10 \mathrm{ml}$ of whole blood samples. Includes:
- 3L Cell Lysis Solution
- $1 \mathrm{~L}$ Nuclei Lysis Solution
- $\quad 350 \mathrm{ml}$ Protein Precipitation Solution
- $150 \mathrm{ml}$ DNA Rehydration Solution
- 1 Protocol

Items Available Separately

Product Size Cat.\#

Cell Lysis Solution 1 liter $\quad$ A7933

Nuclei Lysis Solution 1 liter $\quad$ A7943

Protein Precipitation Solution $\quad 350 \mathrm{ml} \quad \mathrm{A7953}$

DNA Rehydration Solution $\quad 50 \mathrm{ml} \quad$ A7963

RNase A $(4 \mathrm{mg} / \mathrm{ml})$

$1 \mathrm{ml} \quad \mathrm{A7973}$

Storage Conditions: Store the Wizard ${ }^{\circledR}$ Genomic DNA Purification Kit at room temperature $\left(22-25^{\circ} \mathrm{C}\right)$. This system is guaranteed for one year from date of purchase if stored and handled properly.

Promega Corporation - 2800 Woods Hollow Road - Madison, WI 53711-5399 USA - Toll Free in USA 800-356-9526- Telephone 608-274-4330 - Fax 608-277-2516 - www.promega.com 
IMPORTANT!

...Blood must be collected in EDTA-, heparin- or citrate-anticoagulant tubes to prevent clotting.
Completely resuspend the white blood cells to obtain efficient cell lysis.

\section{Protocols for Genomic DNA Isolation}

We have tested the purification of genomic DNA from fresh whole blood collected in EDTA-, heparin- and citrate-anticoagulant tubes, and have detected no adverse effects upon subsequent manipulations of the DNA, including PCR (3).

Anticoagulant blood samples may be stored at $2-8^{\circ} \mathrm{C}$ for up to two months, but DNA yield will be reduced with length of storage.

The protocol in Section III.A has been designed and tested for blood samples up to $3 \mathrm{ml}$ in volume. The protocol in Section III.B has been designed and tested for blood samples up to $10 \mathrm{ml}$ in volume. The yield of genomic DNA will vary depending on the quantity of white blood cells present. Frozen blood may be used in the following protocols, but yield may be lower than that obtained using fresh blood, and additional Cell Lysis Solution may be required.

Caution: When handling blood samples (Sections III.A, B and C), follow recommended procedures at your institution for biohazardous materials or see reference 2 .

A. Isolation of Genomic DNA from Whole Blood (300 $\mu$ l or $3 \mathrm{ml}$ Sample Volume)

Materials to Be Supplied by the User

- sterile $1.5 \mathrm{ml}$ microcentrifuge tubes (for $300 \mu$ l blood samples)

- sterile $15 \mathrm{ml}$ centrifuge tubes (for $3 \mathrm{ml}$ blood samples)

- water bath, $37^{\circ} \mathrm{C}$

- isopropanol, room temperature

- $70 \%$ ethanol, room temperature

- water bath, $65^{\circ} \mathrm{C}$ (optional; for rapid DNA rehydration)

1. For $300 \mu$ l Sample Volume: Add $900 \mu l$ of Cell Lysis Solution to a sterile $1.5 \mathrm{ml}$ microcentrifuge tube.

For $3 \mathrm{ml}$ Sample Volume: Add $9.0 \mathrm{ml}$ of Cell Lysis Solution to a sterile $15 \mathrm{ml}$ centrifuge tube.

2. Gently rock the tube of blood until thoroughly mixed; then transfer blood to the tube containing the Cell Lysis Solution. Invert the tube 5-6 times to mix.

3. Incubate the mixture for 10 minutes at room temperature (invert 2-3 times once during the incubation) to lyse the red blood cells. Centrifuge at $13,000-16,000^{\circ} g$ for 20 seconds at room temperature for $300 \mu l$ sample. Centrifuge at $2,000^{\circ} \mathrm{g}$ for 10 minutes at room temperature for $3 \mathrm{ml}$ sample.

4. Remove and discard as much supernatant as possible without disturbing the visible white pellet. Approximately $10-20 \mu$ l of residual liquid will remain in the $1.5 \mathrm{ml}$ tube $(300 \mu \mathrm{l}$ sample). Approximately $50-100 \mu \mathrm{l}$ of residual liquid will remain in the $15 \mathrm{ml}$ tube ( $3 \mathrm{ml}$ sample).

If blood sample has been frozen, repeat Steps 1-4 until pellet is white. There may be some loss of DNA from frozen samples.

Note: Some red blood cells or cell debris may be visible along with the white blood cells. If the pellet appears to contain only red blood celis, add an additional aliquot of Cell Lysis Solution after removing the supernatant above the cell pellet, and then repeat Steps 3-4.

5. Vortex the tube vigorously until the white blood cells are resuspended (10-15 seconds).

\footnotetext{
Promega Corporation - 2800 Woods Hollow Road - Madison, WI 53711-5399 USA - Toll Free in USA 800-356-9526 - Telephone 608-274-4330 - Fax 608-277-2516 - www.promega.com Part\# TM050 


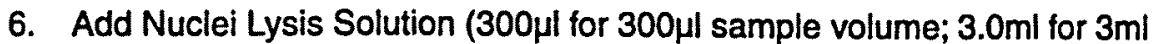
sample volume) to the tube containing the resuspended cells. Pipet the solution 5-6 times to lyse the white blood cells. The solution should become very viscous. If clumps of cells are visible after mixing, incubate the solution at $37^{\circ} \mathrm{C}$ until the clumps are disrupted. If the clumps are still visible after 1

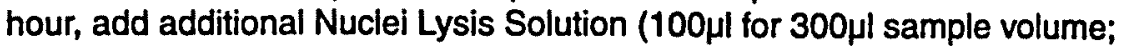
$1.0 \mathrm{ml}$ for $3 \mathrm{ml}$ sample volume) and repeat the incubation.

7. Optional: Add RNase Solution (1.5 $\mu$ l for $300 \mu l$ sample volume; $15 \mu$ for $3 \mathrm{ml}$ sample volume) to the nuclear lysate and mix the sample by inverting the tube $2-5$ times. Incubate the mixture at $37^{\circ} \mathrm{C}$ for 15 minutes, and then cool to room temperature.

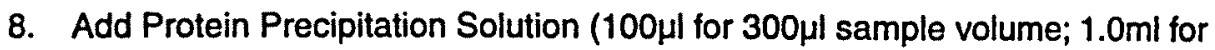
$3 \mathrm{ml}$ sample volume; see Note in margin) to the nuclear lysate and vortex vigorously for 10-20 seconds. Small protein clumps may be visible after vortexing.

9. Centrifuge at $13,000-16,000^{-} g$ for 3 minutes at room temperature for $300 \mu l$ sample volume. Centrifuge at $2,000^{\circ} g$ for 10 minutes at room temperature for $3 \mathrm{ml}$ sample volume.

A dark brown protein pellet should be visible. If no pellet is observed, refer to Section IV.

10. For $300 \mu \mathrm{l}$ sample volume, transfer the supernatant to a clean $1.5 \mathrm{ml}$ microcentrifuge tube containing $300 \mu \mathrm{l}$ of room temperature isopropanol. For $3 \mathrm{ml}$ sample volume, transfer the supernatant to a $15 \mathrm{ml}$ centrifuge tube containing $3 \mathrm{ml}$ room temperature isopropanol.

11. Gently mix the solution by inversion until the white thread-like strands of DNA form a visible mass.

12. Centrifuge at $13,000-16,000^{-} g$ for 1 minute at room temperature for $300 \mu l$ sample. Centrifuge at $2,000^{\circ} \mathrm{g}$ for 1 minute at room temperature for $3 \mathrm{ml}$ sample. The DNA will be visible as a small white pellet.

13. Decant the supernatant and add one sample volume of room temperature $70 \%$ ethanol to the DNA. Gently invert the tube several times to wash the DNA pellet and the sides of the microcentrifuge tube. Centrifuge as in Step 12.

14. Carefully aspirate the ethanol using either a drawn Pasteur pipette or a sequencing pipette tip. The DNA pellet is very loose at this point and care must be used to avoid aspirating the pellet into the pipette. Invert the tube on clean absorbent paper and air-dry the pellet for 10-15 minutes.

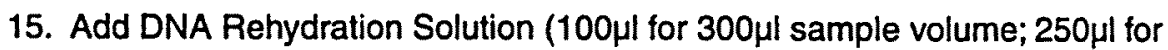
$3 \mathrm{ml}$ sample volume) to the tube and rehydrate the DNA by incubating at $65^{\circ} \mathrm{C}$ for 1 hour. Periodically mix the solution by gently tapping the tube. Alternatively, rehydrate the DNA by incubating the solution overnight at room temperature or at $4^{\circ} \mathrm{C}$.

16. Store the DNA at $2-8^{\circ} \mathrm{C}$.
Note: If additional Nuclei Lysis Solution was added in Step 6, add a total of 130ul Protein Precipitation Solution for $300 \mu l$ sample volume and $1.3 \mathrm{ml}$ Protein Precipitation Solution for $3 \mathrm{ml}$ sample volume at Step 8.

Note: At Step 10, some supernatant may remain in the original tube containing the protein pellet. Leave this residual liquid in the tube to avoid contaminating the DNA solution with the precipitated protein. 
Esquema resumido da Reação de Polimerização em Cadeia (PCR), método preconizado por Kimura et al (1997).

Sequiência dos "primers" (sintetizados pela Invitrogen do Brasil):

1) Gênero-específico ( $1^{\circ}$ Ciclo):

P1 - 5' ACG ATC AGA TAC CGT CGT AAT CTT 3'

P2 - 5' GAA CCC AAA GAC TTT GAT TTC TCA T 3'

2) Espécie-específicos $\left(2^{\circ} \mathrm{Ciclo}\right)$ :

P. falciparum (F2) - 5'CAA TCT AAA AGT CAC CTC GAA AGA TG 3'

P. vivax (V1) - 5'CAA TCT AAG AAT AAA CTC CGA AGA GAA A 3'

P. malariae (M1) - 5'GGA AGC TAT CTA AAA GAA ACA CTC ATA T 3'

$10^{\circ}$ Reacão:

1 Ciclo: $92^{\circ} \mathrm{C}-2$ minutos

35 Ciclos: $92^{\circ} \mathrm{C}-30$ segundos

$60^{\circ} \mathrm{C}-90$ segundos

$60^{\circ} \mathrm{C}-5$ minutos

\section{Reacão:}

1 Ciclo: $92^{\circ} \mathrm{C}-2$ minutos

18 Ciclos: $92^{\circ} \mathrm{C}-30$ segundos

$$
\begin{aligned}
& 60^{\circ} \mathrm{C}-1 \text { minuto } \\
& 60^{\circ} \mathrm{C}-5 \text { minutos }
\end{aligned}
$$

Tamanho dos fragmentos amplificados ( $P$. vivax, $P$. falciparum e $P$. malariae): $100 \mathrm{pb}$ 